Florida International University FIU Digital Commons

$6-27-2018$

\title{
Saltwater Intrusion and Vegetation Shifts Drive Changes in Carbon Storage in Coastal Wetlands
}

Sean Patrick Charles

schar056@fiu.edu

DOI: $10.25148 /$ etd.FIDC006842

Follow this and additional works at: https://digitalcommons.fiu.edu/etd

Part of the Biology Commons

\section{Recommended Citation}

Charles, Sean Patrick, "Saltwater Intrusion and Vegetation Shifts Drive Changes in Carbon Storage in Coastal Wetlands" (2018). FIU Electronic Theses and Dissertations. 3791.

https://digitalcommons.fiu.edu/etd/3791 


\section{FLORIDA INTERNATIONAL UNIVERSITY}

Miami, Florida

\section{SALTWATER INTRUSION AND VEGETATION SHIFTS DRIVE CHANGES IN CARBON STORAGE IN COASTAL WETLANDS}

A dissertation submitted in partial fulfillment of

the requirements for the degree of

DOCTOR OF PHILOSOPHY

in

BIOLOGY

by

Sean P. Charles

2018 
To: Dean Michael R. Heithaus

College of Arts, Sciences and Education

This dissertation, written by Sean P. Charles, and entitled Saltwater Intrusion and Vegetation Shifts Drive Changes in Carbon Storage in Coastal Wetlands, having been approved in respect to style and intellectual content, is referred to you for judgment.

We have read this dissertation and recommend that it be approved.

$\begin{array}{r}\hline \text { Steven Pennings } \\ \hline \text { Steven Oberbauer } \\ \hline \text { Michael Ross } \\ \hline \text { Tiffany Troxler } \\ \hline \text { John Kominoski, Major Professor }\end{array}$

Date of Defense: June 27, 2018

The dissertation of Sean P. Charles is approved.

Dean Michael R. Heithaus

College of Arts, Sciences and Education

Andrés G. Gil

Vice President for Research and Economic Development and Dean of the University Graduate School

Florida International University, 2018 
(C) Copyright 2018 by Sean P. Charles

All rights reserved. 


\section{ACKNOWLEDGMENTS}

Pursuing my $\mathrm{PhD}$ has been the most fulfilling and wonderful adventure of my life. However, it has also been one of the hardest things I have ever done, and without the help of many people, I never would have made it to this point. I would like to first and foremost thank my advisor, Dr. John Kominoski, for giving me the support and guidance to pursue my goals and the freedom to develop my research. Dr. Kominoski has helped me to realize what is possible in a scientific career and how to achieve it. Before working for John, I wouldn't have had the audacity to apply for a number of grants and opportunities that I ultimately achieved. John showed me that becoming a professional scientist takes an incredible amount of work and that the only antidote to a life of hard work is to embrace it with love and to take (a little) time to play hard as well. As well as being a great mentor as a researcher, John introduced me to a number of unique teaching experiences from 150-person lecture halls at FIU to 9 person natural amphitheaters in Yellowstone National Park.

I have been extremely lucky to have an amazing inspirational dissertation committee. I'd like to thank Mike Ross for involving me in his fascinating research exploring decades of ecosystem change in South Florida. Mike was always excited to talk about potential drivers of ecosystem change, and has incredible, extensive knowledge of the Everglades. After every field day with Mike I felt like I had learned a lot and also that I had been on a helicopter, which was amazing. I'd like to thank Steve Pennings for including me in an incredible project in Texas, and excluding me from the back-breaking labor involved in establishing it (I'm just kidding I would have loved to help). Steve showed me that you can be a serious scientist without always having to be serious. I've thoroughly enjoyed Steve's extreme 
curiosity about science (he studied sea-hares!), his playful nature and his choice in boats (Mud buddy is the king of boats). Steve Oberbauer illustrates the beauty of being a professor. He obviously loves the adventure of being a scientist, traveling between Costa Rica, Alaska and the Everglades. On top of that, he maintains a Mr. Wizard's workshop at FIU in Miami, in which students learn to create advanced scientific equipment from any scrap you can find. I would like to thank Tiffany Troxler for being a great example of how to be both a scientist and a powerful advocate for change. It's an honor to learn to stuff mesh bags with peat moss from someone with a local (Sea level rise solutions center) and global (the United Nations) policy audience. Finally, I would like to say thank you to the entire committee for great feedback on manuscripts and the dissertation.

I would like to thank a number of graduate students for helping with the 3 essential C's for completing a $\mathrm{PhD}$ (communication, collaboration and commiseration). Thank you to my great lab-mates, Shelby Servais, Ben Wilson, Matt Smith, Ximena Messa and Dong Yoon Lee (although you are really our superior). I'd also like to thank James Stroud, Jenn Sweatman, Mike Bush, Ross Boucek, Danielle Ogurcak and many more for their friendship and support.

I have had a number of incredible employees, interns and volunteers over the period of my PhD. I'd like to thank Hanna Campen for spending a whole summer in the Everglades to help on an internship from the German government. Coming from Kiel in Northern Germany to South Florida in August was certainly a shock, but I couldn't have asked for anyone better to work with. I'd like to thank Patricia Leroy for volunteering in the lab, turning her volunteer position into an internship and after its expiration asking if she could 
continue anyway. This eventually lead to a part-time job and I appreciate Patricia's pleasant, trustworthy demeanor and great attitude for over two years. I'd also like to thank Julio Pachon and Claudia Garcia for tons of help in the lab and the field.

I'd like to thank my funding sources for all the help. I'm grateful to FIU for providing TA funding and allowing me to teach Ecology lab (the best class on campus). Thank you to Dr. Kominoski for using his startup fund to provide invaluable funding to start our research in Texas and to fund any gaps in coverage. Funding from the Everglades Foundation For Everglades Fellowship and the National Science Foundation Doctoral Dissertation Fellowship made my my research in the Ten Thousand Islands possible (chapter 4). I'd also like to thank the Florida Coastal Everglades Long Term Ecological Research program and Florida Seagrant for funding on chapter 1, Texas Seagrant for funding on chapter 2 and Everglades National Park for funding and support on chapter 3.

I'd like to thank my family for emphasizing the importance of education at every turn and for always being there for me. Finally, I'd like to thank my wonderful girlfriend Lela for always supporting me throughout this process by letting me live bizarre hours while writing, giving me love and support always and providing comfort and lasagna when I really needed it. 
ABSTRACT OF THE DISSERTATION

SALTWATER INTRUSION AND VEGETATION SHIFTS DRIVE CHANGES IN

CARBON STORAGE IN COASTAL WETLANDS

By

\author{
Sean P. Charles \\ Florida International University, 2018 \\ Miami, Florida \\ Professor John Kominoski, Major Professor
}

Coastal wetlands protect coastlines through efficient storage of organic carbon (OC) that decreases wetland vulnerability to sea level rise (SLR). Accelerated SLR is driving saltwater intrusion and altering vegetation communities and biogeochemical conditions in coastal wetlands with uncertain implications. We quantified changes in OC stocks and fluxes driven by 1) saltwater and phosphorous intrusion on freshwater and brackish marshes, 2) vegetation along an experimental saltmarsh to mangrove gradient, 3) saltwater intrusion and vegetation change across a marsh to mangrove ecotone, and 4) vegetation change and mangrove forest development along a marsh to mangrove ecotone. Increasing salinity in freshwater marshes decreased root biomass and soil elevation within one year. In brackish marshes, increased salinity decreased root productivity and biomass and increased root breakdown rate $(k)$, while added salinity did not increase elevation loss. In our experimental marsh-mangrove ecotone, mangrove vegetation promoted higher organic carbon (OC) storage by increasing above and belowground biomass and reducing organic matter $k$. However, mangroves also increased belowground $k$, and decreased allochthonous marine subsidies, indicating the potential for 
OC storage trade-offs. In the Southeast Everglades, we identified strong interior-coastal gradients in soil stoichiometry and mangrove cover. Interior freshwater soil conditions increased $k$, while total soil OC stocks decreased toward the coast indicating that saltwater intrusion is driving large scale soil OC loss. In the southeast Everglades, mangrove expansion increased root biomass and root productivity, but did not mitigate the overall loss of OC stocks toward the coast. Similarly, in the southwest Everglades, saltwater intrusion drove a decrease in soil OC. However, mangrove encroachment drove a rapid recovery and increased OC stocks. Mangrove encroachment doubled aboveground biomass within the last ten years, increased it 30 times in the last 30 years, and doubled belowground biomass after 20 years. Our research shows that 1) moderate saltwater intrusion without mangrove encroachment will lead to a loss in OC stocks and potentially lead to wetland elevation loss and submergence, 2) in the absence of a change in saltwater intrusion, mangrove expansion can enhance OC storage 3) mangrove expansion can mitigate OC loss during saltwater intrusion, but this pattern depends on mangrove recruitment and ecosystem productivity. 


\section{TABLE OF CONTENTS}

CHAPTER

PAGE

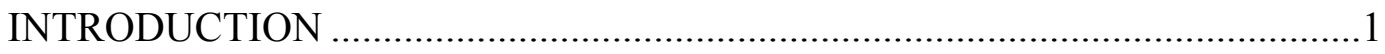

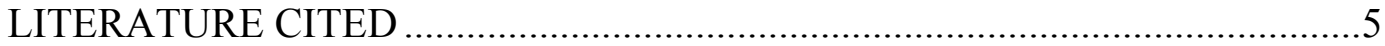

I. EXPERIMENTAL SALTWATER INTRUSION DRIVES RAPID

LOSS OF SOIL ELEVATION AND LONG-TERM REDUCTION IN

CARBON ACCUMULATION IN COASTAL WETLANDS.

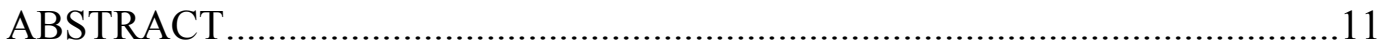

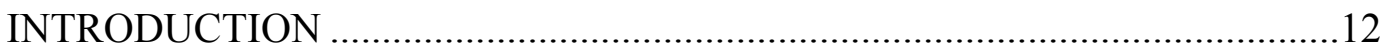

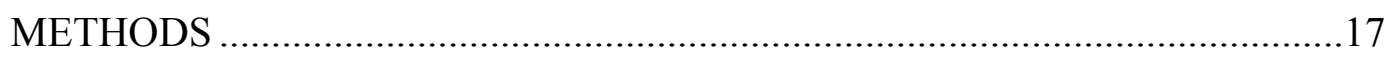

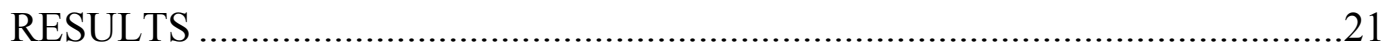

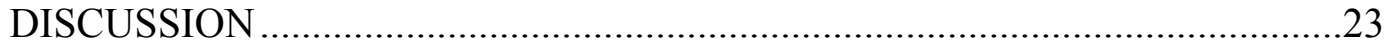

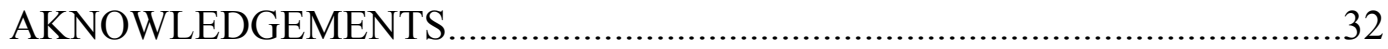

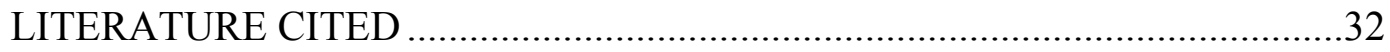

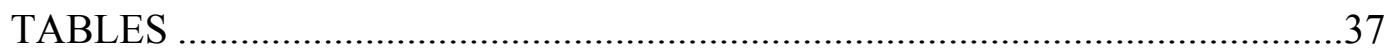

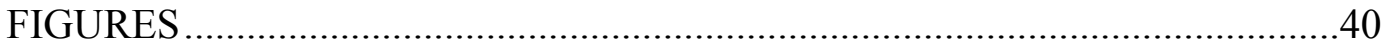

II. MANGROVES INCREASE ORGANIC CARBON STORAGE IN AN EXPERIMENTAL MARSH-MANGROVE GRADIENT DESPITE REDUCED MARINE SUBSIDIES.....................................................45

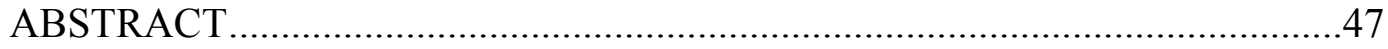

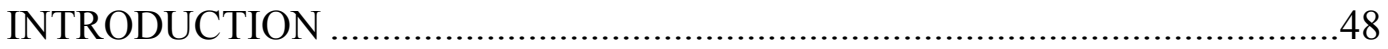

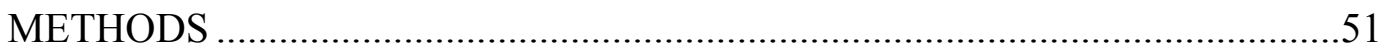

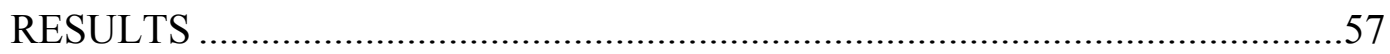

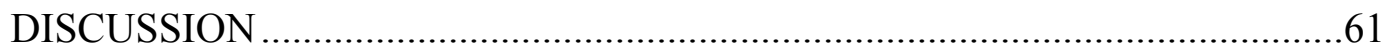

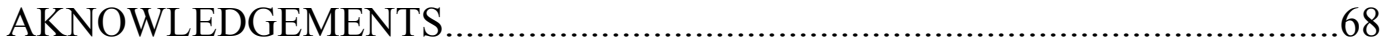

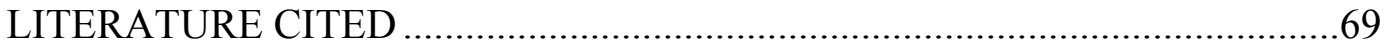

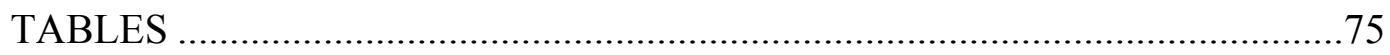

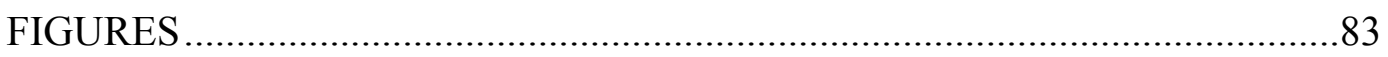

III. SOIL ORGANIC CARBON STOCKS DECREASE WITH

SALTWATER INTRUSION DESPITE MANGROVE ENCROACHMENT IN THE FLORIDA COASTAL

EVERGLADES ......................................................................... 91

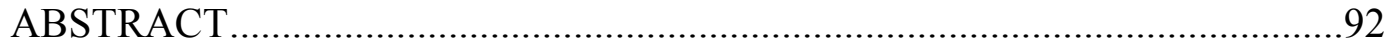

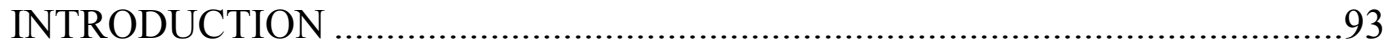

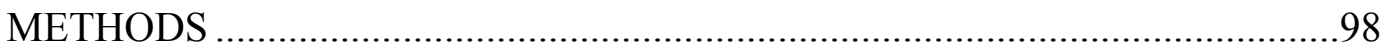

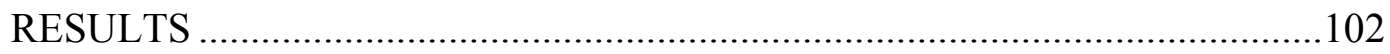

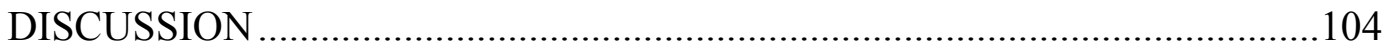




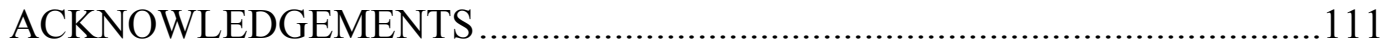

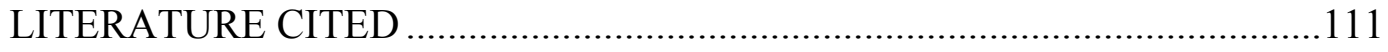

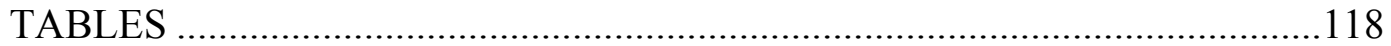

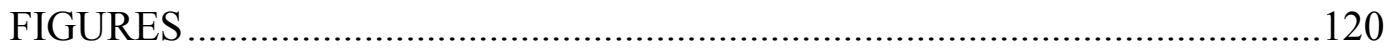

IV. QUANTIFYING CHANGES IN ORGANIC CARBON STORAGE

WITH VARIATION IN PLANT IDENTITY AND AGE ALONG A COASTAL MARSH-MANGROVE

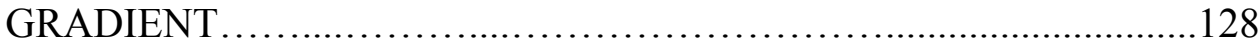

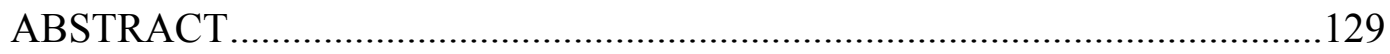

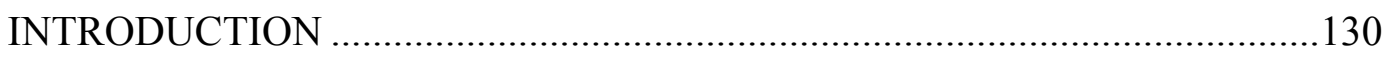

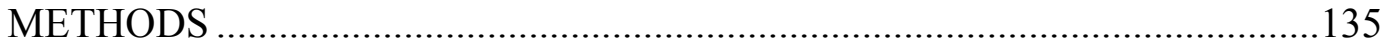

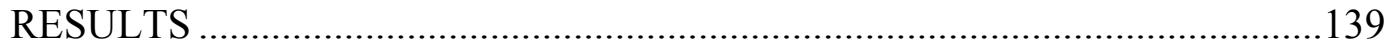

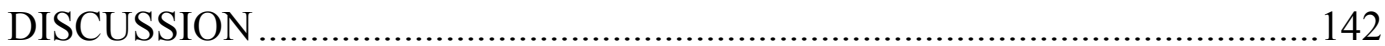

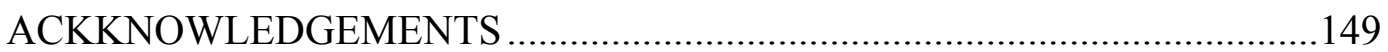

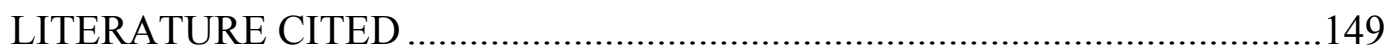

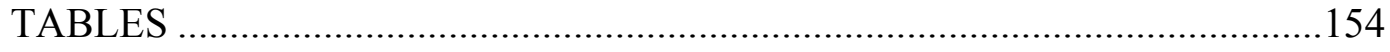

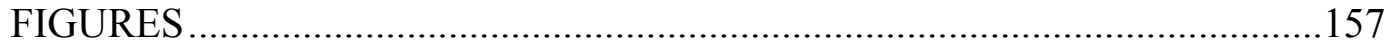

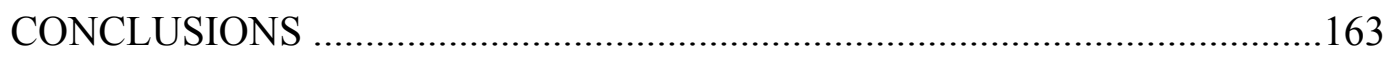

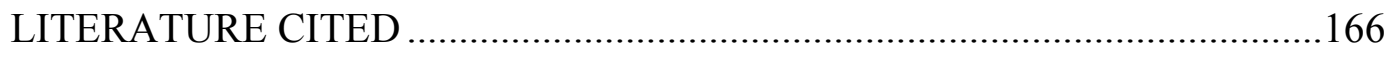

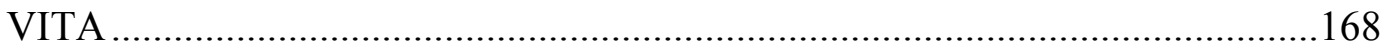




\section{LIST OF TABLES}

TABLE

PAGE

\section{CHAPTER I}

1 Soil OC change in response to salinity and phosphorus addition in a freshwater marsh mesocosm experiment. Mean and standard error for each treatment type $(n=6$ per treatment). The driver and direction of effects and significant $\mathrm{P}$-values from 2-way analysis of variance (ANOVA) included

2 Soil OC change in response to salinity addition and increased inundation in a brackish marsh mesocosm experiment. Mean and standard error for each treatment type $(n=6$ per treatment). The driver and direction of effects and significant $\mathrm{P}$-values from 2-way ANOVAs included

3 Decomposing organic matter stoichiometry in the freshwater marsh mesocosm experiment after 361 days ( $n=6$ per treatment). Average litter and root nutrient concentration and standard error $(\% \mathrm{C}, \% \mathrm{~N}, \% \mathrm{P})$ and molar nutrient ratios (C:N, C:P, N:P. For each treatment type (Fresh, Fresh $+\mathrm{P}$, Salt, Salt $+\mathrm{P}), \mathrm{n}=6$.

\section{CHAPTER II}

1 Drivers of patch level stocks and fluxes of output from linear models. We list average and standard deviation of stocks, and fluxes of organic carbon (OC) in $3 \cdot 3 \mathrm{~m}$ patches based on vegetation type (mangrove and marsh) and location(interior and fringe). Additionally, we identify minimum adequate models with AICc, from the model: Response $=\operatorname{Patch}(p) \bullet \operatorname{Plot}(P) \bullet$ $\operatorname{Plot}(P)^{2} \cdot \operatorname{Location}(l)$, where Patch is patch vegetation type ("marsh" or "mangrove"), Plot is the percent mangrove cover at the $(24 \cdot 42 \mathrm{~m})$ plot scale. We list $P$ and adjusted $\mathrm{R}^{2}$ values for each model.

2 Plot weighted average responses to mangrove cover. We identified relationships between plot weighted average values and percent plot mangrove cover. We report either linear or quadratic relationships based on $\mathrm{AICc}$ for each response variable.

3 Organic matter stoichiometry. We report mean and standard error of total carbon $(\% \mathrm{C})$, total nitrogen $(\% \mathrm{~N})$ and total phosphorus $(\% \mathrm{P})$ and their molar ratios $(\mathrm{C}: \mathrm{N}, \mathrm{C}: \mathrm{P}, \mathrm{N}: \mathrm{P})$ for litter and roots before (initial) and after 
field incubation and in surface accretion after 22 months

\section{CHAPTER III}

$1 \quad$ Linear mixed-effects models and model weights of fixed effects quantified from significant relationships between distance to coast and soil nutrient characteristics $(\% \mathrm{~N}, \% \mathrm{P}, \mathrm{C}: \mathrm{N}, \mathrm{N}: \mathrm{P}$ ratios $)$ and vegetation characteristics (mangrove cover, marsh cover and total cover). Additionally, we quantified the effects of distance to coast, soil nutrient characteristics and vegetation characteristics on soil carbon stocks and fluxes were. Response variables and fixed predictors were standardized with the equation variable $=(x-\operatorname{mean}(x)) / \operatorname{stdev}(x)$ to ensure that variables were on similar scales and to meet the assumptions of normality. Vegetation characteristics were measured in $1 \mathrm{~m}^{2}$ plots, while soil characteristics were measured with one soil core in the center of each site. Carbon stocks and fluxes were measured in three plots per site. We list only the most parsimonious models for each response, as determined by lowest AICc, and any models whose AICc is within 2 points of the top model (Burnham and Anderson 2002).

\section{CHAPTER IV}

1 Mean and SE of aboveground biomass in ecosystem types. We show total, total herbaceous and species-specific woody plant biomass as OC $\mathrm{m}^{2}$, and the proportion of total aboveground biomass contributed by each mangrove species

2 Mean and SE of belowground OC stocks in each ecosystem type. OC stocks are separated into belowground biomass stock and proportion OC by mass in each soil depth.

3 Mean and SE of soil fluxes for each ecosystem type. We show breakdown rates of ecosystem specific leaves and roots calculated from loss of ash free dry mass over 1 year. Surface accretion is elevation change over one year, and root productivity in organic carbon inputs per year 


\section{LIST OF FIGURES}

FIGURES

PAGE

\section{CHAPTER I}

1 Soil organic carbon (OC) stocks and flux rates in response to elevated salinity and phosphorus additions in the freshwater marsh mesocosm experiment. A. Rates of root productivity over $361 \mathrm{~d}$, normalized to

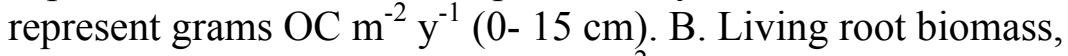
normalized to represent grams OC $\mathrm{m}^{-2}(0-15 \mathrm{~cm})$. C. Root breakdown rates in surface soil as proportion of ash-free dry mass (AFDM) remaining after 1 year $(0-7.5 \mathrm{~cm})$. D. Root breakdown rates in deeper soil as proportion of AFDM remaining after 1 year $(7.5-15 \mathrm{~cm})$. E. Litter breakdown rates on the soil surface as proportion AFDM remaining after 1 year. F. Changes in soil elevation $(\mathrm{cm})$ after 1 year measured from fixed benchmarks. Letters indicate significant differences among treatments using two-way analysis of variance and Tukey's honest significant difference test $(P<0.05)$.

2 Litter breakdown and elevation change through time in the freshwater marsh mesocosm experiment. A. Salinity decreased soil elevation over the course of $361 \mathrm{~d}$. Salinity caused a rapid elevation loss between 65 and 166 days, after which elevations remained similar $(P<0.05)$. B. There was no difference in proportion leaf litter AFDM remaining after $80 \mathrm{~d}$, but Fresh $+\mathrm{P}$ and Fresh became significantly different after $166 \mathrm{~d}$, and all $\mathrm{P}$ treatments broke down faster after 267 and $361 \mathrm{~d}(P<0.01)$.

3 Soil organic carbon (OC) stocks and flux rates in response to elevated salinity and inundation in the brackish marsh mesocosm experiment. A. Rates of root productivity over $361 \mathrm{~d}$, normalized to represent grams OC m $\mathrm{m}^{-2} \mathrm{y}^{-1}(0-15 \mathrm{~cm})$. B. Living root biomass, normalized to represent grams OC $\mathrm{m}^{-2}(0-15 \mathrm{~cm})$. C. Root breakdown rates in surface soil as proportion of ash-free dry mass (AFDM) remaining after $1 \mathrm{y}(0-7.5 \mathrm{~cm})$. D. Root breakdown rates in deeper soil as proportion of AFDM remaining after 1 year $(7.5-15 \mathrm{~cm})$. E. Litter breakdown rates on the soil surface as proportion AFDM remaining after $1 \mathrm{y}$. F. Changes in soil elevation $(\mathrm{cm})$ after $361 \mathrm{~d}$ normalized to represent one year measured from fixed benchmarks. Letters indicate significant differences among treatments using analysis of variance and Tukey's honest significant difference $(P<0.05$

\section{CHAPTER II}


1 Organic carbon standing stocks A. Patch-scale aboveground biomass $(P<$ $0.001)$ B. Plot-weighted average aboveground biomass $\left(\mathrm{R}^{2}=0.95 ; P=\right.$ $0.02)$ C. Patch-scale belowground biomass $(P=0.01)$ D. Plot-weighted average belowground biomass $\left(\mathrm{R}^{2}=0.57 ; P=0.05\right)$ E. Patch-scale surface soil \% organic carbon $(P<0.05) \mathrm{F}$. Plot-weighted average soil \% organic carbon $(P>0.05$.

Surface organic carbon accretion A. 11 month patch-scale treatment by plot-scale mangrove cover $\left(\mathrm{R}^{2}=0.52 ; P=0.02\right) \mathrm{B}$. 11 month plot-weighted average surface organic carbon accretion $\left(\mathrm{R}^{2}=0.74 ; P=\right.$ $0.04)$ C. 22 month patch-scale treatment by plot level mangrove cover excluding fringe plots (interior only). Open circles represent marsh patches and their relationship to plot cover is represented by the line of best fit and $95 \%$ confidence intervals $\left(\mathrm{R}^{2}=0.21 ; P=0.02\right)$, black circles represent mangrove patches D. 22 month plot-weighted average organic carbon accretion $(P>0.05)$.

Microclimate A. PAR interception patch-scale treatment by plot-scale mangrove cover. Black circles represent mangrove patches $\left(\mathrm{R}^{2}=0.34 ; P\right.$ $=0.04)$, open circles represent marsh patches $(P>0.05) \mathrm{B}$. PAR interception plot-weighted average $\left(\mathrm{R}^{2}=0.74 ; P<0.001\right) \mathrm{C}$. Temperature patch-scale treatment by plot-scale cover. Black circles represent mangrove patches, open circles represent marsh patches $(P>$ $0.05)$ D. Temperature plot-weighted average $\left(\mathrm{R}^{2}=0.74 ; P=0.004\right)$.

Surface organic matter breakdown A. Patch-scale wood standard substrate breakdown $(\mathrm{P}>0.05) \mathrm{B}$. Plot-weighted average wood standard substrate breakdown $\left(\mathrm{R}^{2}=0.29 ; P=0.06\right) \mathrm{C}$. Patch-scale cellulose standard substrate breakdown $(P=0.03)$ D. Plot-weighted average cellulose standard substrate breakdown $\left(\mathrm{R}^{2}=0.48 ; P=0.04\right)$ E. Patch-scale mangrove litter breakdown $(P=0.04) \mathrm{F}$. Plot-weighted average mangrove litter breakdown $\left(\mathrm{R}^{2}=0.66 ; P=0.003\right)$.

5 Belowground organic matter breakdown $(0-15 \mathrm{~cm})$ A. Patch-scale wood standard substrate breakdown $(0-15 \mathrm{~cm})(P=0.03)$ B. Plot-scale wood standard substrate breakdown $(0-15 \mathrm{~cm})\left(\mathrm{R}^{2}=0.42 ; P=0.07\right) \mathrm{C}$. Patch-scale root species specific breakdown $(0-15 \mathrm{~cm})(P=0.03) \mathrm{D}$. Plot-scale weighted average root species specific breakdown $(0-15 \mathrm{~cm})$ $\left(\mathrm{R}^{2}=0.71 ; P=0.04\right)$.

Belowground organic matter breakdown $(15-30 \mathrm{~cm})$ A. Patch-scale wood 
standard substrate breakdown $(15-30 \mathrm{~cm})(P=0.04)$ B. Plot-weighted average wood standard substrate breakdown $(15-30 \mathrm{~cm})(P>0.05) \mathrm{C}$. Patch-scale root species specific breakdown $(15-30 \mathrm{~cm})(P=0.03) \mathrm{D}$. Plot-weighted average root species specific breakdown $(15-30 \mathrm{~cm})\left(\mathrm{R}^{2}=\right.$ $0.52 ; P=0.04)$.

\section{CHAPTER III}

1 Conceptual model predicting the influence of proximity to coast on ecosystem properties and soil carbon storage. The size of plusses and minuses indicate the hypothesized magnitude of each ecosystem link. We predicted that saltwater intrusion from sea level rise and water management will drive saltwater influence further inland, thus influencing carbon stocks and fluxes on different time scales.

2 Site map. We chose 19 sites that spanned the marsh-mangrove ecotone in the Southeast Saline Everglades in Florida, USA. Sites were chosen based on location within and adjacent to the marsh-mangrove ecotone, and because previous data (Ross et al. 2000) on vegetation shows that this region has experienced large change in vegetation type and cover.

Proximity to the coast and vegetation and soil characteristics. We compared distance to coast (the location of each measurement to the closest open coastline) to vegetation and soil characteristics using generalized mixed effects models. For each measurement we accounted for spatial autocorrelation by creating a random effect of location (transect/region). Solid lines represent best fit from linear mixed effects models $(P<0.05)$, and dashed lines are 95 percent confidence intervals. A. Mangrove cover measured within $1 \mathrm{~m}^{2}$ vegetation plots that we utilized for root biomass and $\mathrm{OC}$ measurements. B. Percent nitrogen $(\% \mathrm{P})$ in the surface soil $(0-15 \mathrm{~cm})$ taken from the center of each site $(n=19)$. C. Soil molar carbon to nitrogen ratios $(\mathrm{C}: \mathrm{N})$ in the surface soil $(0-15 \mathrm{~cm})$ taken from the center of each site. D. Soil molar nitrogen to phosphorus ratios in the surface soil $(0-15 \mathrm{~cm})$ taken from the center of each site.

Soil carbon fluxes. We used generalized mixed effects models to identify the drivers of root productivity and organic matter breakdown. For each measurement we accounted for spatial autocorrelation by creating a random effect of location (transect/region). Solid lines represent best fit from linear mixed effects models $(P<0.05)$, and dashed lines are 95 percent confidence intervals. A. The most parsimonious model to describe root ingrowth was a linear model with mangrove cover as the sole driver. Root productivity was measure as ingrowth $(0-30 \mathrm{~cm})$ and normalized as grams of OC per year. B. Wood standard substrates breakdown was 
measured in the surface soil $(10 \mathrm{~cm})$ and breakdown rates were normalized per degree day to represent $k \mathrm{dd}^{-1}$

Soil carbon stocks. We used generalized mixed effects models to identify the drivers of root productivity and organic matter breakdown. For each measurement we accounted for spatial autocorrelation by creating a random effect of location (transect/region). Solid lines represent best fit from linear mixed effects models $(P<0.05)$, and dashed lines are 95 percent confidence intervals. A. The best model to predict root biomass solely included mangrove cover. We measured live roots from root cores (30 cm deep) taken from the center of $1 \mathrm{~m}^{2}$ vegetation plots. Root biomass is expressed as OC content. B. The model that best predicted surface soil OC $(0-15 \mathrm{~cm})$ was distance from coast. Soil cores were taken adjacent to root cores and we measured distance from the location of each core location to the nearest open coastline....

6 We used a piecewise structural equation models (Lefcheck 2015) to measure linkages between proximity to the coast, vegetation and soil chemical characteristics, soil carbon fluxes (root productivity and organic matter breakdown rates) and soil carbon stocks (root biomass and soil organic carbon content). The corresponding model list is composed of linear mixed effects models (individual statistical output described in table 1), run with the R package "Ime4". We ran the model in R with the package "piecewiseSEM." We identified the most parsimonious overall model and removed linkages to minimize AICc. We show only significant correlations $(P<0.05)$ as standardized path coefficients. We display all soil characteristics, stocks and fluxes of OC from our original conceptual figure (figure 1) despite the lack of significant linkages between them.......121

\section{CHAPTER IV}

1 Conceptual model showing a reduction in soil $\mathrm{C}$ pools with salinity intrusion when vegetation community remains the same (represented by $\mathrm{C}$ with green arrows). Marsh OC storage decreases with saltwater intrusion, but the rate and trend of decrease are unclear. The establishment of halophytes (represented by $\mathrm{C}$ with red yellow and blue arrows) and their development through time could lead to increased $\mathrm{C}$ loss, recovery or net $\mathrm{C}$ sequestration through time. In Ten Thousand Islands National Wildlife Refuge, the halophytes that become established are mostly mangroves which store OC, potentially replacing and surpassing marsh OC through time.

2 Images of our experimental setting and mangrove encroachment. We increasingly focus in on our study area, beginning with A. the location of Ten Thousand Islands National Wildlife Refuge (TTINWR), B. mangrove 
extent in TTINWR in 1927, 1940 and 2006 based on aerial photography, C. two of our transects, illustrating different plot types, across a landscape of shifting vegetation D. the change in mangrove cover from 2006 to 2016 based on historical aerial imagery and E. displaying the view from the brackish marsh, looking toward mangroves of increasing age, including a photo of mangrove seedlings in the marsh understory....

3 Organic carbon stocks in A. aboveground biomass and B. belowground biomass in each ecosystem type. Mangrove classes are Mangrove 1 (0-10 years old), Mangrove 2 (10-20 years old), Mangrove 3 (20-30 years old), Mangrove 4 (30-70 years old), Mangrove 5 (75-88 years old). Letters represent differences in ecosystem type based on Tukey HSD tests, with significant differences for $p<0.05$.

4 Proportion organic matter by mass in soil at A. 0-5 cm soil depth B. 5-15 cm soil depth C. 15-30 cm soil depth and D. 30-45 cm soil depth. Mangrove classes are Mangrove 1 (0-10 years old), Mangrove 2 (10-20 years old), Mangrove 3 (20-30 years old), Mangrove 4 (30-70 years old), Mangrove 5 (75-88 years old). Letters represent differences in ecosystem type based on Tukey HSD tests, with significant differences for $p<0.05$

$5 \quad$ Organic matter breakdown rates expressed as $k \mathrm{~d}^{-1}$ of ash free dry mass for A. leaf litter on the soil surface B. 0-15 cm deep roots and C. 15-30 cm deep roots. Mangrove classes are Mangrove 1 ( 0 -10 years old), Mangrove 2 (10-20 years old), Mangrove 3 (20-30 years old), Mangrove 4 (30-70 years old), Mangrove 5 (75-88 years old). Letters represent differences in ecosystem type based on Tukey HSD tests, with significant differences for $p<0.05$.

6 Soil inputs of A. total surface accretion B. organic carbon inputs as root productivity. Mangrove classes are Mangrove 1 ( 0 -10 years old), Mangrove 2 (10-20 years old), Mangrove 3 (20-30 years old), Mangrove 4 (30-70 years old), Mangrove 5 (75-88 years old). Letters represent differences in ecosystem type based on Tukey HSD tests, with significant differences for $p<0.05$. 


\section{INTRODUCTION}

Coastal wetlands exist at the intersection of marine and terrestrial ecosystems, which both creates the setting to provide an inordinate level of ecosystem services (Barbier et al. 2011; Costanza et al. 2014) and leaves them particularly susceptible to environmental change (White and Kaplan 2017). Coastal wetlands improve water quality, protect inland environments from storms and sea level rise (SLR), provide habitat for threatened and economically valuable organisms, and sequester atmospheric carbon in vegetation and soils (Barbier et al. 2011; Costanza et al. 2014). High productivity and low decomposition in hydric soils allows wetlands to store organic carbon (OC) 50 times more effectively than terrestrial ecosystems (McLeod et al. 2011). Coastal wetlands primarily store OC belowground, where it has provided substrate for many wetlands to build vertical elevation and survive slow rates of SLR for millennia (Woodroffe et al. 1990; McKee et al. 2007). However, global SLR has accelerated from an average of 1.7 $\mathrm{mm} \mathrm{y}^{-1}$ over the last century to $>3 \mathrm{~mm} \mathrm{y}^{-1}$ in the last 25 years (Nerem et al. 2018), and local coastal areas in South Florida have experienced rates of $9 \mathrm{~mm} \mathrm{y}^{-1}$ (Wdowinski et al. 2016). As the rate of SLR accelerates, coastal wetlands will only survive if they increase their soil elevation at a rate that is equal to or exceeds SLR (Cahoon et al. 2006; Morris et al. 2002), leading to conflicting predictions of both mass submergence of coastal wetlands (Kirwan and Megonigal 2013; Morris et al. 2016) and predictions that biophysical feedbacks, will allow most coastal wetlands to survive in place (Kirwan et al. 2016).

Coastal wetland OC storage is strongly influenced by hydrology, soil and water chemistry and vegetation dynamics (Deegan et al. 2012; Webster et al. 2013; Kelleway et 
al. 2017), all of which are being altered by climate change. Coastal ecosystems are experiencing saltwater intrusion and shifts in hydrology across the world from a combination of accelerating SLR and local anthropogenic freshwater manipulation (Herbert et al. 2015). Similarly, shifts in temperature and saltwater intrusion are driving shifts in the structure and function of coastal wetland vegetation (Ross et al. 2000; Saintillan et al. 2014; Osland et al. 2016). The influence of saltwater intrusion, vegetation change and their interaction on specific stocks and fluxes of $\mathrm{OC}$ are poorly understood, but are likely critical factors in future OC storage and wetland vulnerability.

Freshwater and brackish marshes in the Florida Coastal Everglades are experiencing saltwater intrusion, shifts in inundation and increased phosphorus $(\mathrm{P})$ availability because of SLR and freshwater management. The Everglades is highly susceptible to saltwater intrusion and inundation from SLR due to low elevation (mostly below $1.5 \mathrm{~m}$ above current sea level; Titus and Richmon 2002) and projected SLR of 1-2 m this century (Haigh et al. 2014). The extent of saltwater intrusion in the Everglades is determined by the balance between fresh and marine water (Dessu et al. 2018), and while SLR increases marine influence in the Florida Coastal Everglades, freshwater availability has been drastically reduced by creating 1000s of miles of canals to drain wetlands for development and agriculture (Sklar et al. 2005; McVoy et al. 2011), exacerbating saltwater intrusion, particularly belowground as saltwater moves inland through porous limestone during dry conditions (Price et al. 2006). Finally, saltwater intrusion increases the availability of the limiting nutrient (P) (Childers et al. 2006), particularly due to the rapid desorption of $\mathrm{P}$ from limestone during initial saltwater intrusion into freshwater wetlands (Price et al. 2010; Flower et al. 2017). 
Saltwater intrusion into freshwater and brackish marshes dominated by Cladium jamaicense (sawgrass) both subsidizes and stresses vegetation (the primary source of OC inputs) and heterotrophic microbes (the primary source of OC loss), with uncertain impacts on ecosystem OC stocks and fluxes. Initial saltwater intrusion into sawgrass marshes drives enhanced aboveground productivity as the subsidy of $\mathrm{P}$ outweighs the stress of added salinity, but increasing salinity stress decreases vegetation biomass and productivity and cause plant mortality (Ewe et al. 2006, Troxler et al. 2014).

Furthermore, roots are often the most important source of soil OC (McKee et al. 2007; Deegan et al. 2012) and the impacts of salinity and $\mathrm{P}$ on belowground productivity and biomass accumulation are less well understood than aboveground processes. Similarly, saltwater intrusion can both reduce breakdown rate $(k)$ by stressing heterotrophic microbial communities with salinity (Neubauer 2013) and increase $k$ through subsidies of P (Feller et al. 1999; Qualls and Richardson 2000) and sulfate, which provides a more effective alternative electron acceptor in low-oxygen wetland soil (Weston et al. 2011; Neubauer et al. 2013; Chambers et al. 2014). Finally, excessive inundation can decrease vegetation productivity and biomass (Kirwan and Megonigal 2013) and $k$ by reducing oxygen availability (Ise et al. 2008).

Climate change is also driving changes in vegetation dominance as increasing temperature allows mangrove trees to expand their range poleward (Osland et al. 2013; Cavanaugh et al. 2014; Armitage et al. 2015) and saltwater intrusion allows mangroves to encroach inland (Ross et al. 2000; Krauss et al. 2011; Rogers et al. 2006; Kelleway et al. 2016; Saintillan et al. 2014). Shifts in dominant plant communities may alter OC storage by changing the quantity and quality of autochthonous organic matter (Twilley et al. 
1986), altering microclimate (Fierer et al. 2005; D’Odorico et al. 2013) and deposition of allochthonous organic matter (Fagherazzi et al. 2006). It is unclear how vegetation transitions from marsh to mangrove are likely to impact soil OC storage, with studies comparing adjacent vegetation types demonstrating increased soil OC storage in mangroves (Bianchi et al. 2013; Comeaux et al. 2013), no difference (Perry and Mendelssohn 2009; Henry and Twilley 2013; Doughty et al. 2015; McKee et al. 2017), or differences only in certain environmental conditions (Yando et al. 2016). In particular, it is unclear how mangrove encroachment, shifts in hydrology and saltwater intrusion are likely to impact OC storage through space and time.

In this dissertation I quantified the impacts of saltwater intrusion, marsh to mangrove transitions and the interacting effects of saltwater intrusion and vegetation shifts on specific OC stocks and fluxes. In Chapter I, I isolated the major abiotic impacts of saltwater intrusion (enhanced salinity, $\mathrm{P}$ and inundation depth) in Everglades freshwater and brackish sawgrass marsh mesocosms to quantify impacts on OC stocks (belowground biomass and \%OC), OC fluxes (root and litter $k$ and root productivity) and soil elevation change. In Chapter II, I used a large-scale field experiment to manipulate mangrove and marsh vegetation to create a gradient of mangrove cover in Port Aransas, TX. By manipulating vegetation in situ, we isolated the impact of marsh and mangrove vegetation from abiotic conditions to quantify changes in $\mathrm{OC}$ stocks and fluxes at multiple spatial scales. In Chapter III, I quantified relationships among distance from the coast, mangrove vegetation and soil chemistry across the Southeast Saline Everglades, a region that has experienced extensive saltwater intrusion, patchy mangrove establishment and the expansion of a low biomass "white zone." We then analyzed relationships 
between OC stocks and fluxes, vegetation identity and cover and soil characteristics. In Chapter IV, I identified 7 vegetation plot types (freshwater marsh, brackish marsh, 0-10 year old mangrove, 10-20 year old mangrove, 20-30 year old mangrove, 30-70 year old mangrove and $>88$ year old mangrove) based on current conditions and aerial photography identifying times since mangrove establishment. Chapter I is formatted for submission to Estuaries and Coasts. Chapter II has been submitted to Ecology. Chapter III is formatted for submission to Ecological Applications. Chapter IV has been formatted for submission to Ecology.

\section{LITERATURE CITED}

Baustian, J. J., I. A. Mendelssohn, and M. W. Hester. 2012. Vegetation's importance in regulating surface elevation in a coastal salt marsh facing elevated rates of sea level rise. Global Change Biology 18:3377-3382.

Bernal, B., J. P. Megonigal, and T. J. Mozdzer. 2017. An invasive wetland grass primes deep soil carbon pools. Global Change Biology 23:2104-2116.

Cahoon, D. R., P. Hensel, J. Rybczyk, K. L. McKee, C. E. Proffitt, and B. C. Perez. 2003. Mass tree mortality leads to mangrove peat collapse at Bay Islands, Honduras after Hurricane Mitch. Journal of Ecology 91:1093-1105.

Chambers, L. G., S. E. Davis, and T. G. Troxler. 2015. Sea Level Rise in the Everglades: Plant-Soil-Microbial Feedbacks in Response to Changing Physical Conditions. Pages 89-112 in J. A. Entry, editor. Microbiology of the Everglades Ecosystem. CRC Press, Boca Raton.

Childers, D. L., D. Iwaniec, D. Rondeau, G. Rubio, E. Verdon, and C. J. Madden. 2006. Responses of sawgrass and spikerush to variation in hydrologic drivers and salinity in Southern Everglades marshes. Hydrobiologia 569:273-292.

Deegan, L. A., D. S. Johnson, R. S. Warren, B. J. Peterson, J. W. Fleeger, S. Fagherazzi, and W. M. Wollheim. 2012. Coastal eutrophication as a driver of salt marsh loss. Nature 490:388. 
Delaune, R. D., J. A. Nyman, and W. H. Patrick. 1994. Peat collapse, ponding and wetland loss in a rapidly submerging coastal marsh. Journal of Coastal Research 10:1021-1030.

Herbert, E. R., P. Boon, A. J. Burgin, S. C. Neubauer, R. B. Franklin, M. Ardon, K. N. Hopfensperger, L. P. M. Lamers, and P. Gell. 2015. A global perspective on wetland salinization: ecological consequences of a growing threat to freshwater wetlands. Ecosphere 6.

Larcher, W. 2003. Physiological plant ecology. 4th edition. Springer, Berlin.

Light, S. S., and J. W. Dineen. 1994. Water control in the Everglades: A historical perspective. Pages 47-84 in S. M. Davis and J. C. Ogden, editors. Everglades: The Ecosystem and its Restoration. St. Lucie Press, Delray Beach.

McVoy, C. W., W. P. Said, J. Obeysekera, J. Van Arman, and T. W. Dreschel. 2011. Landscapes and Hydrology of the Predrainage Everglades. University of Florida Press, Gainesville, FL.

Mitsch, W. J., and J. G. Gosselink. 2007. Wetlands. 4th ed. edition. John Wiley \& Sons, Inc., Hoboken, NJ.

Nahlik, A. M., and M. S. Fennessy. 2016. Carbon storage in US wetlands. Nature Communications 7.

Neubauer, S. C. 2013. Ecosystem responses of a tidal freshwater marsh experiencing saltwater intrusion and altered hydrology. Estuaries and Coasts 36:491-507.

Nyman, J. A., R. D. Delaune, and W. H. Patrick. 1990. Wetland soil formation in the rapidly subsiding Mississippi River Deltaic Plain - mineral and organic-matter relationships. Estuarine Coastal and Shelf Science 31:57-69.

Nyman, J. A., R. J. Walters, R. D. Delaune, and W. H. Patrick, Jr. 2006. Marsh vertical accretion via vegetative growth. Estuarine Coastal and Shelf Science 69:370-380.

Pearlstine, L. G., E. V. Pearlstine, and N. G. Aumen. 2010. A review of the ecological consequences and management implications of climate change for the Everglades. Journal of the North American Benthological Society 29:1510-1526.

Pezeshki, S. R., R. D. DeLaune, and W. H. Patrick Jr. 1987a. Response of the freshwater marsh species, Panicum hemitomon Schult., to increased salinity. Freshwater Biology 1:195-200. 
Pezeshki, S. R., R. D. Delaune, and W. H. Patrick. 1987b. Effects of flooding and salinity on photosynthesis of Sagittaria lancifolia. Marine Ecology Progress Series 41:8791.

Rejmankova, E., and P. Macek. 2008. Response of root and sediment phosphatase activity to increased nutrients and salinity. Biogeochemistry 90:159-169.

Richardson, C. J., A. Dickson, and M. Ho. 2008. The Effects of Disturbance, Phosphorus, and Water Level on Plant Succession in the Everglades. Pages 531-544 Everglades Experiments. Springer, New York.

Ryan, M. G., and B. E. Law. 2005. Interpreting, measuring, and modeling soil respiration. Biogeochemistry 73:3-27.

Saha, A. K., S. Saha, J. Sadle, J. Jiang, M. S. Ross, R. M. Price, L. Sternberg, and K. S. Wendelberger. 2011. Sea level rise and South Florida coastal forests. Climatic Change 107:81-108.

Troxler, T. G., D. L. Childers, and C. J. Madden. 2014. Drivers of Decadal-Scale Change in Southern Everglades Wetland Macrophyte Communities of the Coastal Ecotone. Wetlands 34:S81-S90.

Valentine, D. L. 2002. Biogeochemistry and microbial ecology of methane oxidation in anoxic environments: a review. Antonie Van Leeuwenhoek International Journal of General and Molecular Microbiology 81:271-282.

Voss, C. M., R. R. Christian, and J. T. Morris. 2013. Marsh macrophyte responses to inundation anticipate impacts of sea-level rise and indicate ongoing drowning of North Carolina marshes. Marine Biology 160:181-194.

Wanless, H. R., and B. M. Vlaswinkel. 2005. Coastal landscape and channel evolution affecting critical habitats at Cape Sable, Everglades National Park, Florida.

Wdowinski, S., R. Bray, B. P. Kirtman, and Z. H. Wu. 2016. Increasing flooding hazard in coastal communities due to rising sea level: Case study of Miami Beach, Florida. Ocean \& Coastal Management 126:1-8.

Webster, K. L., J. W. McLaughlin, Y. Kim, M. S. Packalen, and C. S. Li. 2013. Modelling carbon dynamics and response to environmental change along a boreal fen nutrient gradient. Ecological Modelling 248:148-164.

Whalen, S. C. 2005. Biogeochemistry of methane exchange between natural wetlands and the atmosphere. Environmental Engineering Science 22:73-94. 
Whittle, A., and A. V. Gallego-Sala. 2016. Vulnerability of the peatland carbon sink to sea-level rise. Scientific Reports 6. 


\section{CHAPTER I}

EXPERIMENTAL SALTWATER INTRUSION DRIVES RAPID LOSS OF SOIL ELEVATION AND LONG-TERM REDUCTION IN CARBON ACCUMULATION IN COASTAL WETLANDS 


\section{Experimental saltwater intrusion drives rapid soil elevation loss and long-term}

reduction in carbon accumulation in coastal wetlands

Sean P. Charles ${ }^{1}$, John S. Kominoski ${ }^{1}$, Tiffany G. Troxler ${ }^{1}$, Evelyn E. Gaiser ${ }^{1}$, Shelby M. Servais $^{1}$, Benjamin J. Wilson ${ }^{1}$, Stephen E. Davis ${ }^{2}$, Fred H. Sklar ${ }^{3}$, Carlos CoronadoMolina $^{3}$, Christopher J. Madden ${ }^{3}$, Steve Kelly ${ }^{3}$, and David T. Rudnick ${ }^{4}$

${ }^{1}$ Florida International University, Dept. of Biological Sciences and Southeast

Environmental Research Center, Miami, FL 33199

${ }^{2}$ Everglades Foundation, Palmetto Bay, FL 33157

${ }^{3}$ South Florida Water Management District, West Palm Beach, FL 33406

${ }^{4}$ Everglades National Park, Homestead, FL 33034 


\begin{abstract}
The rate of sea-level rise (SLR) is increasing worldwide, and the associated effects of saltwater intrusion on coastal wetlands are uncertain. Saltwater intrusion can increase salinity, marine-derived nutrients, and inundation depths in brackish and freshwater wetlands, but the individual and combined effects of these changes on soil organic carbon (OC) and marsh elevation have not been quantified. In two mesocosm experiments using sawgrass (Cladium jamaicense) plant-soil monoliths from the Florida Everglades, we simulated hydrologic and biogeochemical changes associated with SLR and saltwater intrusion. In freshwater wetland mesocosms, we compared ambient and elevated salinity $(8.8 \pm 0.18 \mathrm{ppt})$ and phosphorus $\left(\mathrm{P},+3.08 \pm 0.01 \mathrm{~g} \mathrm{~m}^{-3} \mathrm{yr}^{-1}\right)$ for one year. Elevated salinity reduced living root biomass by $48 \%$ but did not impact root productivity or litter and root breakdown rates. Elevated salinity treatments lost soil elevation $(-2.6 \pm 0.3 \mathrm{~cm}$ loss $)$, while treatments receiving freshwater exhibited a marginal increase in elevation $(+0.46 \pm 0.5 \mathrm{~cm})$. Added $\mathrm{P}$ increased root productivity by $130 \%$ but had no effect on living root biomass or soil elevation. In brackish wetland mesocosms, we increased salinity from $9.7 \pm 0.2 \mathrm{ppt}$ to $18.9 \pm 0.5 \mathrm{ppt}$ and compared inundated $(5-\mathrm{cm}$ depth) and exposed (-2-cm depth) conditions. Root productivity decreased by $70 \%$, living root biomass decreased by $41 \%$, and root $k$ in surface soil increased by $9 \%$ with elevated salinity. However, we found no effects of salinity or inundation on brackish soil elevation, but all brackish soils lost elevation during the experiment (mean $=0.64 \pm 0.15$

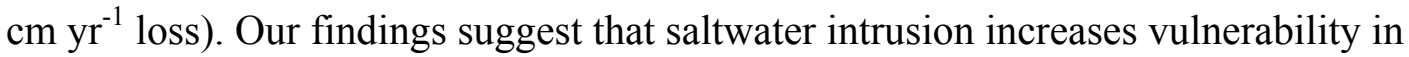
freshwater and brackish wetlands, due to rapid soil elevation loss and net reductions in
\end{abstract}


soil OC storage with elevated salinity that are not offset by added phosphorus or inundation.

\section{INTRODUCTION}

Peat soils in coastal wetlands develop slowly over centuries to millennia, as organic carbon $(\mathrm{OC})$ inputs from primary production outpace slow rates of organic matter decomposition in inundated soils, allowing coastal wetlands to store more organic carbon (OC) per area than other ecosystems (Chmura et al. 2003; McLeod et al. 2011). By storing OC coastal wetlands provide a carbon sink to mitigate climate change (Griscom et al. 2017) and OC storage in belowground biomass and soils drives wetland surface elevation change (Nyman et al. 2006; McKee et al. 2007; Neubauer 2008), allowing many coastal wetlands to maintain elevation with gradual rates of sea-level rise (SLR) (Woodroffe 1990; McKee et al. 2007). As the rate of SLR accelerates, coastal wetlands are predicted to experience increased saltwater intrusion and inundation in the coming century (Kirwan and Megonigal 2013; Morris et al. 2016). Much of the uncertainty over coastal wetland vulnerability concerns the degree to which biophysical feedbacks associated with climate change will enhance or diminish soil OC storage and vertical elevation gain (Kirwan et al. 2016). Furthermore, saltwater intrusion and eutrophication may cause loss of stored OC and lead to wetland submergence (Cahoon et al. 2003; Deegan et al. 2012).

The location of freshwater and brackish coastal wetlands in the landscape influences vulnerability to saltwater intrusion and altered inundation from accelerated rates of SLR and human disturbance (White and Kaplan 2017). Saltwater intrusion is 
occurring in coastal wetlands worldwide (Herbert et al. 2015) as rates of SLR accelerated from $1.7 \mathrm{~mm} \mathrm{y}^{-1}$ during the last century to $\sim 3 \mathrm{~mm} \mathrm{y}^{-1}$ in the last 25 years (Nerem et al. 2018). Therefore, it is critical to understand how altered hydrologic and biogeochemical conditions affect marsh OC storage and feedback to alter soil elevation, which influence marsh vulnerability. Recent rates of SLR in South Florida have increased even more drastically from $7.7 \mathrm{~mm} \mathrm{y}^{-1}$ in 2011 to $22 \mathrm{~mm} \mathrm{y}^{-1}$ in 2016 (Wdowinski et al. 2016; Dessu et al. 2018). Saltwater intrusion is often exacerbated by reduced freshwater availability, as climate change increases evaporation and alters precipitation. In many ecosystems saltwater intrusion is further compounded by upstream anthropogenic alterations that continue to reduce freshwater flow (Trenberth et al. 2014; Dessu et al. 2018).

In peatlands, $\mathrm{OC}$ storage drives elevation change, particularly through root production and OC accumulation (Nyman et al. 1993; Nyman et al. 2006; Morris et al. 2016), but saltwater intrusion and inundation may alter OC stocks and fluxes. Saltwater intrusion can alter plant productivity and biomass allocation by introducing stressors (salinity, inundation and hydrogen sulfide) and resources (marine nutrients) that increase productivity and biomass (Huston 1997; Krauss et al. 2009; Neubauer 2013; Herbert et al. 2015). Similarly, moderate inundation can increase plant productivity, but in excess, causes plant mortality and conversion of open water (Kirwan and Megonigal 2013; Troxler et al. 2014). Similarly, saltwater intrusion can reduce the breakdown rate of OC by stressing microbes (Neubauer 2013) or increase breakdown rates with subsidies of marine-derived nutrients (Qualls and Richardson 2008) and sulfate to serve as an alternative electron acceptor in reduced wetland soils (Weston et al. 2011; Neubauer et al. 2013; Chambers et al. 2013). Finally, SLR and water management can alter inundation, 
which decreases OC breakdown by encouraging the development of reduced soil conditions (Ise et al. 2008).

The Everglades is the largest subtropical peatland in the world, and has developed OC rich soils over $\sim 5000$ years (McVoy et al. 2011), but this vast and shallow-sloping, P-limited ecosystem is being drastically altered by saltwater intrusion. Saltwater intrusion and inundation levels in the Everglades ecotone are driven by the balance of fresh and marine water (Dessu et al. 2018). Because the majority of the Everglades is $<1.5 \mathrm{~m}$ above sea level (Titus and Richman 2001), 1 - 2 m of projected SLR (Haigh et al. 2014) this century is likely to drive widespread saltwater intrusion and inundation. Additionally, since the 1880 s, freshwater flow to the Everglades has been drastically reduced through the creation of $2500 \mathrm{~km}$ of canals designed to drain wetlands for development and agriculture (Sklar et al. 2005, McVoy et al. 2011). The combination of SLR and reduced freshwater availability has already created widespread saltwater intrusion into freshwater and brackish wetlands (Ross et al. 2000, White and Kaplan 2017). Saltwater intrusion is negatively related to aboveground sawgrass productivity across the Everglades landscape (Ewe et al. 2006; Macek and Rejmankova 2008; Troxler et al. 2014). However, there is often no impact of salinity on aboveground sawgrass productivity at low salinity levels (Macek and Rejmankova 2007), and the best predictor of productivity is duration of salinity levels above 30 ppt (Troxler et al. 2014). Over the past half century, saltwater intrusion has driven the interior expansion of a zone of sparse vegetation (the "white zone") into what was previously denser-canopied freshwater marsh (Egler 1952; Ross et al. 2000). 
Sawgrass marshes in the Everglades are highly P-limited, but saltwater intrusion increases P availability (Sandoval et al. 2016), particularly in freshwater marshes experiencing initial saltwater intrusion (Flower et al. 2017). A lack of upland sediment sources, long water residence times and high rates of biological uptake and sorption limits P in freshwater marshes. Saltwater contains more available P than Everglades freshwater (Childers et al. 2006), and during initial saltwater intrusion, $P$ adsorbed to limestone bedrock is rapidly released, providing an additional short-term pulse of $\mathrm{P}$ along the leading edge of saltwater intrusion (Price et al. 2010, Flower et al. 2017b). Finally, Everglades restoration involves increasing freshwater availability to create more natural conditions, yet most of the potentially available freshwater contains P concentrations in excess of the $10 \mathrm{ppb}$ threshold deemed damaging to Everglades environmental quality (Sklar et al. 2005). Furthermore, because $\mathrm{P}$ accumulates in soils and biota, even if $\mathrm{P}$ concentration in water is low, increasing water volume will lead to $\mathrm{P}$ loading through time (Gaiser 2009). Therefore, quantifying the relative and interactive effects of elevated $\mathrm{P}$ and salinity on $\mathrm{OC}$ storage and soil elevation changes in coastal peatlands will directly inform restoration (Sklar et al. 2005).

Along the leading edge of saltwater intrusion, $\mathrm{P}$ subsidies often temporarily increase aboveground plant productivity (Ewe et al. 2006; Mancera-Pineda et al. 2009; Troxler et al. 2014). However, the resource-ratio hypothesis explains that plants expend energy in a way that optimizes acquisition of limiting resources at the expense of expending energy on other processes (Tilman 1985). Therefore, as $\mathrm{P}$ becomes more available with SLR, plants may allocate a lower proportion of their energy to nutrient acquiring root production (Gleeson and Tilman 1992; Casteneda-Moyes 2011). Because 
roots and rhizomes of coastal wetlands are often the primary sources of plant material for OC storage and elevation change, understanding the mechanistic drivers of changes in belowground allocation are extremely important (McKee et al. 2007; Deegan et al. 2012).

We used mesocosm experiments to quantify the impacts of SLR and freshwater manipulation on specific OC stocks and fluxes and soil elevation change in freshwater and brackish marshes. To simulate initial saltwater intrusion in freshwater marshes, we quantified the differences on OC stocks and fluxes from ambient (fresh) and enhanced salinity ( 9 ppt) and ambient and enhanced P. In brackish plant-soil monoliths, we compared ambient ( 10 ppt) and elevated ( $\sim 19 \mathrm{ppt})$ salinity levels and increased water levels from $5 \mathrm{~cm}$ below the soil surface to $2 \mathrm{~cm}$ above the soil surface to simulate shifting hydrologic conditions associated with saltwater intrusion from SLR and freshwater manipulation. We predicted that: 1) phosphorus additions to freshwater marshes would increase root productivity and breakdown rates, resulting in moderate increases in net soil OC storage, 2) salinity would decrease OC storage and elevation by decreasing root productivity through plant osmotic stress and increase organic matter breakdown, 3) salinity would decrease root productivity more in brackish water than freshwater marshes due to sawgrass plasticity and an expected salinity threshold between 10 and $19 \mathrm{ppt}$, and 4) salinity and inundation would interact to decrease root productivity and biomass through increased plant osmotic stress and decreased soil oxidation. By quantifying the specific impacts of saltwater intrusion on OC storage and elevation change in freshwater and brackish Everglades sawgrass marshes, our research will help identify environmental conditions associated with marsh vulnerability and help to guide conservation and restoration of coastal wetlands worldwide. 


\section{METHODS}

\section{Experimental Design}

\section{Freshwater marsh mesocosms}

We collected twenty-four plant-peat monoliths $(30 \mathrm{~cm}$ deep $\cdot 30 \mathrm{~cm}$ wide $\cdot 40 \mathrm{~cm}$ long) from a freshwater wetland in the Florida Everglades $\left(25^{\circ} 46^{\prime} 06.1^{\prime \prime} \mathrm{N}\right.$, $80^{\circ} 28^{\prime} 56.2^{\prime \prime} \mathrm{W}$ ), dominated by a dense stand of Cladium jamaicense (sawgrass). After excavating plant-soil monoliths, we placed them in individual plastic bins within burial crypts. We maintained water levels $\sim 1 \mathrm{~cm}$ above the soil surface and conducted a $2 \cdot 2$ factorial design with two factors (salinity and P). In this freshwater marsh experiment, we

aimed to increase salinity from freshwater to $\sim 9 \mathrm{ppt}$ and added $5096 \pm 103 \mathrm{~g} \mathrm{~m}^{-3}$ of salt to each salt-treated sawgrass-peat monolith (Salt and Salt $+\mathrm{P})$ by mixing with source water and adding to ensure proper mixing. For our P treatment, we added $\left(3.08 \pm 0.01 \mathrm{~g} \mathrm{~m}^{-3} \mathrm{yr}^{-}\right.$ $\left.{ }^{1}\right) \mathrm{P}$ continuously as $2.25 \mathrm{mg} \mathrm{L}^{-1}$ diluted phosphoric acid at $0.14 \mathrm{~mL} \mathrm{~min}^{-1}$ to each $\mathrm{P}$ treated sawgrass-peat monolith over the course of $361 \mathrm{~d}$. Water levels were maintained $1 \mathrm{~cm}$ above the soil surface. Total $\mathrm{P}$ and salinity added were calculated by summing the monthly mean load of each constituent added to each sawgrass-peat monolith. Our design created four treatments, each with six sawgrass-peat monoliths to represent freshwater [Fresh], elevated salinity [Salt], freshwater and elevated P [Fresh $+\mathrm{P}]$, and elevated salinity and $\mathrm{P}[$ Salt $+\mathrm{P}])$.

\section{Brackish marsh mesocosms}

We extracted twenty-four plant-soil monoliths $(30$-cm diameter $\cdot 30-\mathrm{cm}$ depth) from a brackish, sawgrass-dominated marsh with peat soil within Shark River Slough in 
Everglades National Park (25¹3'13.5" N, 8050'36.7" W). Plant-soil monoliths were extracted intact on January 7, 2015 from a marsh that was freshwater in the 1950's (Beard et al. 1952), but has experienced saltwater intrusion in ensuing decades, and had $\sim 9$ ppt ambient porewater salinity at the time of collection. Monoliths were extracted from peat soils ( $\sim 1 \mathrm{~m}$ deep), above limestone bedrock. We exposed twenty-four brackish sawgrass-peat monoliths to a $2 \cdot 2$ factorial design altering salinity from ambient $(9.6 \pm$ $0.2 \mathrm{ppt})$ to elevated $(19 \pm 0.5 \mathrm{ppt})$ salinity and altering inundation from exposed (soil surface $4 \mathrm{~cm}$ above water level) to inundated (soil surface $5 \mathrm{~cm}$ below water surface). Our four treatments were: ambient salinity and constant inundation [Amb.inu], elevated salinity and constant inundation [Ele.inu], ambient salinity and exposed surface soil [Amb.exp], and elevated salinity and exposed surface soil [Ele.exp]).

\section{Root Biomass and Productivity}

We measured root productivity in all plant-soil monoliths by deploying cylindrical ingrowth bags $(2.5 \mathrm{~cm}$ diameter, $15 \mathrm{~cm}$ depth) filled with commercial peat moss. Roots were sieved through 1-mm sieves, to separate them from peat, dried at $40^{\circ} \mathrm{C}$ to measure biomass. We then calculated OC concentration as AFDM (as described below) and production rates were standardized to $\mathrm{g} \mathrm{OC} \mathrm{m}^{-2} \mathrm{y}^{-1}$.

In addition, we measured final belowground root biomass from soil cores $(2.5-\mathrm{cm}$ diameter $\cdot 30-\mathrm{cm}$ depth) at the end of the experiment to determine shifts in root biomass stocks. Root cores were sieved through 1-mm mesh sieves. We separated live roots and standardized to $\mathrm{g}$ OC $\mathrm{m}^{-2}$. 


\section{Organic Matter Breakdown Rates}

In the freshwater mesocosms, we incubated sawgrass leaf litter for 80, 166, 267 and $361 \mathrm{~d}$ in 1-mm mesh litterbags (beginning 24 February 2015). Root litter was incubated at $0-7.5 \mathrm{~cm}$ and $7.5-15 \mathrm{~cm}$ depths for $361 \mathrm{~d}$. All organic matter breakdown samples were kept on ice until processing. Organic matter samples were rinsed of sediment with deionized water, dried at $40^{\circ} \mathrm{C}$ until mass stabilized, and weighed for mass remaining. We express organic matter breakdown as proportion ash-free dry mass (AFDM) over one year.

In brackish mesocosms, senescent sawgrass leaf litter was similarly deployed, but due to restricted soil surface area in the brackish experiment we were only able to determine breakdown after $361 \mathrm{~d}$. As in freshwater treatments, root breakdown rates were measured after $361 \mathrm{~d}$, and all litter and root breakdown values are standardized as AFDM for litter and root breakdown were calculated.

\section{Root and Leaf Litter Stoichiometry}

Dried root and leaf samples were ground using an 8000-D ball mill (Spex SamplePrep, Metuchen, New Jersey, USA). Proportion organic matter was calculated from AFDM as loss on ignition in a muffle furnace at $550^{\circ} \mathrm{C}$ for $5.5 \mathrm{~h}$ and assumed fifty percent of organic mass was OC (Karam 1993).

We also compared percent nutrients and nutrient ratios in root productivity, litter and root breakdown experiments to determine the impact of our P treatment in the freshwater mesocosm experiment. We measured carbon $(\mathrm{C})$ and nitrogen $(\mathrm{N})$ content using a Carlo Erba NA 1500 CHN Analyzer (Carlo Erba, Milan, Italy). We measured 
phosphorus content using the ash/acid extraction method followed by spectrophotometric analysis. We calculated elemental ratios $(\mathrm{C}: \mathrm{N}, \mathrm{C}: \mathrm{P}, \mathrm{N}: \mathrm{P})$ as molar mass.

\section{Soil Elevation Change}

Soil elevation change was measured from fixed benchmarks to the soil surface after $65,166,265$ and 361 days of exposure to elevated salinity and phosphorus (freshwater mesocosms) and elevated salinity and inundation (brackish mesocosms). In order to standardize elevation measurements and avoid disturbance from other measurments, we measured distance from two fixed locations within each experimental mesocosm, located $10 \mathrm{~cm}$ North and South of the center of each plot. Our mesocosms were located within concrete burial crypts, which we used as a permanent benchmark above the soil surface and measured distance from crypt edge down to the soil surface. The rate of change was measured as difference from baseline and standardized to

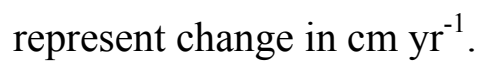

\section{Data Analyses}

We used a two-way analysis of variance (ANOVA) to determine the impact and interaction of our treatments on the freshwater mesocosm experiment (salinity, phosphorus and their interaction) and in the brackish mesocosm experiment (salinity, inundation and their interaction). We used an alpha level of 0.05 to determine significant differences between treatments and where significant differences among response variables were identified, Tukey's HSD post hoc comparison was used to determine the 
differences among treatments. All analyses were performed using R (version 3.3.2, R Core Team 2016).

\section{RESULTS}

\section{Experimental Treatments}

We raised salinity in porewater in our salinity treatments $(8.8 \pm 0.18 \mathrm{ppt})$, compared to fresh treatments $(0.45 \pm 0.01 \mathrm{ppt})$. Similarly, we increased porewater soluble

reactive phosphorus from $\left(0.17 \pm 0.03 \mu \mathrm{mol} \mathrm{L}^{-1}\right)$ in treatments without added $\mathrm{P}$ to $(0.39 \pm$ $\left.0.02 \mu \mathrm{mol} \mathrm{L}{ }^{-1}\right)$ in treatments with added $\mathrm{P}$.

In brackish mesocosms, we increased porewater salinity in added salinity treatments $(18.9 \pm 0.5)$ compared to ambient conditions $(9.7 \pm 0.2)$. Our inundation treatment was maintained at either exposed (soil surface $4 \mathrm{~cm}$ above water level) or inundated (soil surface $5 \mathrm{~cm}$ below water level) conditions.

\section{Root Biomass and Productivity}

In freshwater marsh mesocosms, phosphorus additions increased root productivity $83 \%(+120 \%$ in Fresh + P, $45 \%$ in Salt + P) $(p=0.004$; Figure 1a; Table 1). Salinity decreased final root biomass by $24 \%$ ( $p=0.03$; Figure $1 \mathrm{~b}$; Table 1$)$. In brackish mesocosms, increased salinity decreased root productivity $126 \%(p=0.002$; Figure 3a; Table 3). Additionally, salinity decreased living root biomass $102 \%(p=0.02$; Figure $3 \mathrm{~b}$; Table 3). 


\section{Organic Matter Breakdown Rates}

In freshwater mesocosms, $\mathrm{P}$ increased the rate of leaf litter breakdown on the soil surface $20 \%$ after $361 \mathrm{~d}(p<0.001)$. The breakdown of sawgrass leaf litter was similar among treatments after 65 days of treatment. After $166 \mathrm{~d}$, the Fresh $+\mathrm{P}$ treatment broke down faster than the Fresh treatment, and after $361 \mathrm{~d}$ the Fresh $+\mathrm{P}$, and Salt $+\mathrm{P}$ treatments broke down faster than Fresh and Salt (Figure 2b; Table 1). Belowground, P increased the rate of root breakdown by $10.5 \%$ in the soil surface $(0-15 \mathrm{~cm})(p<0.001$; Figure 1c; Table1), and 5\% in deeper soil $(15-30 \mathrm{~cm})(p=0.007$; Figure 1d; Table 1). Salinity had no impact on root breakdown in freshwater mesocosms $(p>0.05)$

In the brackish wetland experiment, neither added salinity nor inundation impacted leaf litter breakdown on the soil surface $(p>0.05$; Figure $3 \mathrm{e})$. However, belowground, salinity increased root breakdown $2 \%$ at $0-7.5 \mathrm{~cm}(p=0.02$; Figure $3 \mathrm{c}$; Table 3), and inundation decreased root breakdown $4 \%$ at $7.5-15 \mathrm{~cm}(p=0.03$; Figure $3 \mathrm{~d}$; Table 3).

\section{Root and Leaf Litter Stoichiometry}

Concentration of $\mathrm{P}$ in decomposing leaf litter increased by $39 \%$ in the added $\mathrm{P}$ treatments, driving decreases in C:P and N:P ratios $(p<0.001$; Table 2). There was no difference in $\% \mathrm{C}, \% \mathrm{~N}$, or $\% \mathrm{P}$ in root litter $(p>0.05)$. Phosphorus addition decreased $\mathrm{N}: \mathrm{P}$ in decomposing roots in the 0-7.5 cm depth $(p=0.006)$, but did not impact $\mathrm{C}: \mathrm{N}$ or $\mathrm{C}: \mathrm{P}$ ratios $(p>0.05)$. Similarly, $\mathrm{P}$ addition did not impact nutrient ratios in deeper soil $(p>$ 0.05; Table 3). 


\section{Soil Elevation Change}

In freshwater mesocosms, elevated salinity drove soil elevation loss over $361 \mathrm{~d}$ ( $p<0.001)$, driving a $2.8 \pm 0.51 \mathrm{~cm}$ loss with added salinity (Salt) and $2.3 \pm 0.4 \mathrm{~cm}$ in the high salinity and $\mathrm{P}$ treatment $($ Salt $+\mathrm{P})$ (Figure 2a; Table 1). After $166 \mathrm{~d}$, increased salinity drove a decrease in elevation, regardless of $\mathrm{P}$ treatment $(p<0.05)$ (Figure 3; Table 1). After the rapid initial shift, within-treatment elevation remained constant throughout the experiment, and continued to remain similar for 1.5 years (Figure 3).

In brackish mesocosms neither salinity nor inundation treatments had an impact on elevation change $(p>0.05)$. However, all treatments lost elevation $(p=0.007$, mean $=$ $0.77 \mathrm{~cm} \mathrm{y}^{-1}$ loss) (Figure 3f; Table 3).

\section{DISCUSSION}

Our results demonstrate that saltwater intrusion into coastal marshes drives a decrease in OC storage and loss of soil elevation. We found that freshwater wetlands responded to moderate saltwater intrusion ( 0 to $9 \mathrm{ppt})$ with rapid soil elevation loss. Furthermore, salinity increase in brackish marsh (10 to $19 \mathrm{ppt})$ continues to reduce OC storage and all brackish marshes lost elevation. Soil elevation increases with the accumulation of organic and inorganic materials (Morris et al. 2002, Nyman et al. 2006; McKee 2011). However, in peat-rich, non-tidal Everglades marshes, the balance between inputs of organic matter (primarily as root biomass) and losses (breakdown of organic matter and loss of soil $\mathrm{C}$ to the water column) largely determines soil elevation change (Baustian et al. 2012). Although Everglades sawgrass marshes have been a significant $\mathrm{CO}_{2}$ sink during the last 5,000 years, currently it is $\mathrm{CO}_{2}$ neutral on an annual scale (Malone 2014). Subsidies of $\mathrm{P}$ associated with initial saltwater intrusion can increase root 
productivity but also increase the breakdown of roots and leaf litter, with no overall impact on soil elevation. In brackish marshes, increasing salinity leads to increasing OC loss due to reduced productivity and biomass and increasing breakdown rates. Regardless of salinity or inundation treatment, brackish marshes continued to lose elevation, indicating that saltwater intrusion may cause the permanent conversion of sawgrass marshes to open water. Finally, in brackish marshes, increasing freshwater delivery is likely to enhance OC storage because brackish marsh roots broke down more slowly with reduced salinity and increasing inundation, while both root productivity and biomass were higher in lower salinity conditions.

\section{Phosphorus as a subsidy for plant productivity and organic matter breakdown}

Phosphorus addition increased root productivity by $35 \%$, mirroring field data that shows a slight increase in productivity along the leading edge of saltwater intrusion (Ewe et al. 2006; Troxler et al. 2014). Saltwater intrusion has driven an increase in $P$ availability throughout the coastal Everglades (Sandoval et al. 2016) because $\mathrm{P}$ is more available in seawater than freshwater (Childers et al. 2006) and as saltwater intrudes into freshwater marshes, P adsorbed to sediment and limestone bedrock is rapidly released, providing a pulse of $\mathrm{P}$ (Price et al. 2010; Flower et al. 2016; 2017). In the wetland interior, restoration of freshwater to the Everglades has been hampered by excessive $\mathrm{P}$ in available freshwater (Aillery et al. 2001), yet we lack a full understanding of how P impacts specific aspects of OC storage. Roots are frequently the most important longterm OC source to wetlands due to their recalcitrant nature and deposition in low-oxygen 
wetland soils (Twilley 1999; McKee et al. 2007; Chmura 2011; Deegan et al. 2012), and in our study $\mathrm{P}$ increased root productivity.

Phosphorus additions in our study also increased OC loss by enhancing breakdown rates of leaf-litter (18\%), and roots $(11 \%)$, counteracting the influence of increasing OC inputs from primary productivity. A number of studies have shown increased breakdown rates associated with P additions to Everglades litter (Davis 1991; Qualls and Richardson 2008) and peat soils (Newman et al. 2001; Qualls and Richardson 2008) because heterotrophic microbes use available $\mathrm{P}$ to consume organic matter with C:P ratios too high to build microbial biomass (Swift et al. 1979). Because there is much more OC stored as soil organic matter than biomass, the stimulation of breakdown rates are critically important to quantifying climate change feedbacks (Scharlemann et al. 2014).

The net impact of $\mathrm{P}$ addition on OC storage was negligible in our study because $\mathrm{P}$ enhanced both OC inputs from plant productivity and losses from breakdown. In the same experiment, our $\mathrm{P}$ subsidy drove a slight increase in $\mathrm{CO}_{2}$ uptake and sequestration (Wilson et al. in review), but OC storage was insufficient to increase soil elevation. Similarly, P additions has had mixed net impacts on OC storage across the Everglades ecosystem. Craft et al. (1992) found that enhanced OC inputs outweighed enhanced breakdown, driving 50\% higher OC accretion in $\mathrm{P}$ enriched Everglades peat marshes $\left(0.53 \mathrm{~g} \mathrm{~m}^{-2} \mathrm{y}^{-1}\right)$. However, in the highly P enriched Everglades Agricultural Area, decomposition has driven losses in soil elevation at rates as high as $3 \mathrm{~cm}$ per year, particularly after draining wetland soils for agriculture (Volk 1973; Tate 1980). It is important to note that because our study quantified changes over the course of one year, 
our results may differ from chronic $\mathrm{P}$ additions over multiple years. Because sawgrass has a finite ability to use $\mathrm{P}$ to produce biomass, a greater proportion of added $\mathrm{P}$ might be used by soil microbes for organic matter breakdown through time. Furthermore, unlike nitrogen, $\mathrm{P}$ builds in soils once it exceeds the ability of the biota to sequester it (Qualls and Richardson 2008), where it can become re-mineralized and drive additional eutrophication through time (Qian and Richardson, 1997).

Phosphorus addition altered the stoichiometry of decomposing litter but not living root biomass, indicating that microbes rapidly utilize P subsidies to increase breakdown. Ambient nutrient availability drives organic matter breakdown across ecosystems (Woodward et al. 2012), and added $\mathrm{P}$ was rapidly utilized for decomposition. Added $\mathrm{P}$ did not alter root $\mathrm{P}$ concentration or stoichiometry but increased the $\mathrm{P}$ concentration of decomposing litter, indicating that added $\mathrm{P}$ is rapidly utilized by microbes on the soil surface to increase breakdown. In effect, sawgrass roots increased their productivity (adding more OC to the soil), but did not increase litter quality. Because OM stoichiometry is one of the main drivers of breakdown rates (Cornwell et al. 2008), sawgrass organic matter produced under elevated $\mathrm{P}$ conditions is likely to breakdown at similar rates to sawgrass grown in ambient $\mathrm{P}$ conditions. Increasing $\mathrm{P}$ in litter, but not in roots growing in productivity measurements, indicates that $\mathrm{P}$ is increasingly immobilized at the soil surface and utilized for microbial breakdown. Low-level eutrophication may temporarily be sequestered by periphyton and macrophytes, but through time even lowlevel P loading can drive the dissolution of periphyton mats, modify fish utilization (Gaiser et al. 2005), and cause algal (Pan et al. 2000) and vegetation regime shifts (Davis and Ogden 1994; Newman et al. 1998; Daoust and Childers 2004). 


\section{Elevated salinity and inundation effects on carbon storage}

Elevated salinity had a strong negative influence on wetland OC storage in both freshwater and brackish marsh experiments. Increasing salinity from 0 to $7 \mathrm{ppt}$ in the freshwater marsh decreased living root biomass, increased deep root breakdown, and created a trend toward reduced root ingrowth by $30 \%(p>0.05)$. When salinity was increased from 10 to $19 \mathrm{ppt}$, there was a decrease in root productivity (-70\%) and living root biomass $(-45 \%)$. Whereas other species of coastal marsh plants may be killed by salinity increases, sawgrass has a wide salinity tolerance, dominating freshwater marshes and existing at average salinities of $16.4 \mathrm{ppt}$ (Troxler et al. 2014). However, salinity often causes reduced productivity at sub-lethal levels. Macek and Rejmankova (2007) found reduced above and belowground biomass when salinity was raised from $0-5 \mathrm{ppt}$, while Wilson et al. (2015) found decreased productivity at $4.7 \mathrm{ppt}$ compared to $2.3 \mathrm{ppt}$. In other ecosystems, saltwater intrusion may create more obvious and immediate damage to vegetation, whereas the loss of soil OC and elevation in sawgrass marshes may be more cryptic, as sawgrass marshes experience root mortality and reduced productivity.

Based on our results, increased inundation in marshes will likely increase soil OC storage, as it had no impact on plant productivity but reduced the breakdown of roots at 7.5-15 cm soil depth, but did not ultimately alter soil elevation (Table 2). Increased inundation has been shown to increase accretion rates in tidal saltmarshes because allochthonous sediment is only deposited during inundated conditions (Morris et al. 2002). In Everglades marshes, allochthonous sediment generally plays little role, and elevation change is primarily driven by organic matter storage (Craft et al. 1992). Furthermore, the breakdown of soil OC is enhanced in oxidized conditions (Ise et al. 
2008), and while our treatments were not made to simulate drought conditions, more extreme drying events can lead to the loss of soil OC and elevation (Wilson et al. in review).

\section{Sea-level rise and coastal marsh vulnerability}

In understanding wetland vulnerability to SLR, most attention has been given to salt marshes along the coast; however, we identified biophysical feedbacks that increase freshwater and brackish marsh vulnerability kilometers inland. Salinity reduced OC inputs from root productivity, and living root biomass stocks in both freshwater marsh (Figure 1) and brackish marsh experiments (Figure 2). We also measured a loss of soil elevation, driven by salinity, occurring between 65 and 165 days of salinity increased from 0 to 9 ppt. The increase in wetland vulnerability may occur cryptically through a loss in root biomass as root mortality increases. Root mortality leads to a loss of root turgor and, thus, soil volume (Delaune et al. 1994) and may additionally impact soil integrity by decreasing the structure provided by roots allowing soil OC to be eroded or lost to the water column. In our freshwater mesocosms, TOC in the water column increased $220 \%$ with added salinity, indicating a substantial OC loss from the soil (Servais et al. in review), which has also been seen when increasing salinity in mangrove peat soils (Chambers et al. 2013). After 165 days of continuously elevated salinity, elevation changes normalized and did not change significantly over the remaining 6 months of the experiment (Figure 3a). Our results suggest that the most severe impacts of saltwater intrusion occurs upon initial exposure, as root biomass decreases, causing a large flux of soil OC into the water column. 
Saltwater intrusion in freshwater marshes may initially increase productivity and C storage by providing limiting $\mathrm{P}$ to freshwater marshes, however, the stress of salinity ultimately overwhelms productivity gains from saltwater intrusion. Our research illustrates the dynamics underlying a productivity wave generated by saltwater intrusion that may temporarily increase $\mathrm{OC}$ storage as freshwater marshes experience preliminary $\mathrm{P}$ increases (Marcera-Pineda et al. 2009; Wilson et al. in review) from saltwater itself (Childers et al. 2006) and the rapid desorption of $P$ from limestone (Flower et al. 2017). However, through time, saltwater intrusion can drive peat collapse through a loss of root biomass and soil elevation. Our results indicate an initial elevation loss of $2.75 \mathrm{~cm}$ after one year of salt exposure in freshwater marshes. While our brackish experiments did not show a difference in rate of elevation change, both treatments continued to lose elevation, because salt reduced root productivity and root biomass, indicating that marshes are not likely to increase their OC storage and close their elevation deficit as saltwater intrusion continues. Due to the fact that sawgrass marshes are likely to require a decade to accrete $2 \mathrm{~cm}$ vertically under benign conditions (Meeder et al. 2017), it is likely that areas that experience rapid elevation loss through peat collapse will remain permanent open water areas, particularly as SLR continues to accelerate.

\section{Freshwater restoration in coastal wetlands}

Worldwide, more than half of freshwater wetlands have been lost, mostly through draining and diverting water for development and agriculture (Davidson 2014; Thomas et al. 2017). Wetland areas in the Everglades have been reduced by half through the creation of $2500 \mathrm{~km}$ of canals (Davis and Ogden 1994) and existing wetlands are experiencing 
rapid saltwater intrusion due to the combination of SLR and reduced freshwater flow (McVoy et al. 2011; Sklar et al. 2000). The Comprehensive Everglades Restoration Plan seeks to counteract saltwater intrusion by increasing freshwater delivery to the coastal Everglades, but has stalled due to economic and political challenges (CISRERP 2016). Our research illustrates that freshwater restoration may be essential to preserve vegetated coastal wetlands. Without restoration, the Everglades coastal wetlands will continue to experience saltwater intrusion, driving rapid elevation loss and reduced capacity to store OC. Even without saltwater intrusion, sawgrass marshes will struggle to increase their elevation at pace with SLR (Meeder et al. 2017), but by restoring freshwater flow, rapid peat collapse can be avoided or slowed in the near-term, increasing the adaptive capacity of the ecosystem. Because interior marshes in the Everglades rarely accrete faster than $\sim 2 \mathrm{~mm}$ per year (Meeder et al. 2017), a rapid loss of over $2 \mathrm{~cm}$ represents more than a decade of lost accretion. Increasing freshwater delivery can reduce the extent of salinity exposure in freshwater marshes and preserve stored OC in brackish marshes, therefore increasing resilience. Furthermore, rapid soil elevation loss can create conditions in which water is too deep for vegetation recruitment. Therefore, freshwater restoration can buy time for halophyte recruitment and transgression, increasing the likelihood that vegetated wetlands will persist (Gann et al. 2015). In particular, mangrove ecosystems are often capable of faster soil elevation gains than brackish sawgrass marshes (Meeder et al. 2017).

Salinity induces loss of living root biomass, causing the loss of turgor pressure and elevation loss (Delaune et al. 1994). In addition, because living roots stabilize soil, root loss can lead to eroding soils, and, in our case, increase OC loss to the water column 
(Servais et al. in review). Living roots play a critical role in maintaining soil elevation by increasing soil volume and maintaining soil structure. In our study, elevated salinity caused root death and rapidly decreased soil volume due to the loss of turgor pressure (Delaune et al. 1994) and allowed soils to erode, losing OC to the water column (Servais et al. in review). To prevent elevation loss, living roots must either be preserved or replaced by halophyte transgression. The timing of vegetation shifts is essential because once elevation is lost, water depth may prevent halophyte establishment and create permanent open ponds. For example, in Spartina alterniflora marshes, plant die-offs often decrease elevation and prevent vegetation recolonization (Schrift et al. 2008). When vegetation was planted, marsh elevation increased due to intercepting suspended sediment and producing new roots and rhizomes (Hester et al. 2009; Baustian et al. 2012). In the sediment-poor Everglades, organic matter dynamics drive elevation change, particularly through root accumulation (Hatton et al. 1983; Nyman et al. 1993; 2006; Turner et al. 2001; Delaune and Pezeshki 2002). Finally, while there is concern that increasing freshwater restoration may submerge some coastal wetlands (Flower et al. 2017), our results show that increasing inundation depth and decreasing salinity reduced root breakdown in brackish marshes. Furthermore, while our experiment did not simulate drought conditions, much of soil OC and elevation loss occurs when soils are dry and saltwater has intruded (Wilson et al. in review; Malone et al. 2014).

Our results show that saltwater intrusion can cause loss of OC storage in coastal wetlands, driving a loss in soil elevation and perhaps conversion to open water. Wetlands store $20-30 \%$ of all soil C despite occupying only 5-8\% of land area (Mitch and Gosselink 2007; Nahlik and Fennessy 2016). Human activity has decreased wetland area 
by $50-87 \%$ in the last 300 years (Dahl et al. 2011; Davidson et al. 2016). Biophysical feedbacks among abiotic conditions and plant-soil interactions are the largest unknown in the ability of wetlands to mitigate and survive climate change. Our results illustrate that saltwater intrusion is likely to reduce wetland OC storage and reduce resilience to sealevel rise, by driving rapid soil elevation loss in freshwater wetlands, followed by a chronic decrease in OC storage potential as salinity increases.

\section{ACKNOWLEDGMENTS}

Funding for this research was provided by the National Science Foundation's Florida Coastal Everglades Long Term Ecological Research Program (DEB-1237517) and Florida Sea Grant (RC-S-56), with the cooperation of the Everglades Section of the South Florida Water Management District. Additional funding and support was provided by the Everglades Foundation and Everglades National Park. We thank Laura Baumann, Michael Kline, Michelle Robinson and Patricia LeRoy for their help in the field and laboratory. Sean Charles was supported by Florida International University (FIU) Teaching Assistantships, Dr. John Kominoski and the FIU Dissertation Year Fellowship. This is contribution xxxx of the Southeast Environmental Research Center.

\section{LITERATURE CITED}

Cahoon, D. R., P. Hensel, J. Rybczyk, K. L. McKee, C. E. Proffitt, and B. C. Perez. 2003. Mass tree mortality leads to mangrove peat collapse at Bay Islands, Honduras after Hurricane Mitch. Journal of Ecology 91:1093-1105.

Castaneda-Moya, E., R. R. Twilley, V. H. Rivera-Monroy, B. D. Marx, C. CoronadoMolina, and S. M. L. Ewe. 2011. Patterns of Root Dynamics in Mangrove Forests 
Along Environmental Gradients in the Florida Coastal Everglades, USA. Ecosystems 14:1178-1195.

Chambers, L. G., S. E. Davis, T. T. Troxler, J. N. Boyer, A. Downey-Wall, and L. J. Scinto. 2013. Biogeochemical effects of simulated sea level rise on carbon loss in an Everglades mangrove peat soil. Hydrobiologia:doi 10.1007/s10750-1001311764-10756.

Childers, D. L., D. Iwaniec, D. Rondeau, G. Rubio, E. Verdon, and C. J. Madden. 2006. Responses of sawgrass and spikerush to variation in hydrologic drivers and salinity in Southern Everglades marshes. Hydrobiologia 569:273-292.

Chmura, G. L., S. C. Anisfeld, D. R. Cahoon, and J. C. Lynch. 2003. Global carbon sequestration in tidal, saline wetland soils. Global Biogeochemical Cycles 17:12.

Deegan, L. A., D. S. Johnson, R. S. Warren, B. J. Peterson, J. W. Fleeger, S. Fagherazzi, and W. M. Wollheim. 2012. Coastal eutrophication as a driver of salt marsh loss. Nature 490:388-395.

Dessu, S. B., R. M. Price, T. G. Troller, and J. S. Kominoski. 2018. Effects of sea-level rise and freshwater management on local water levels and water quality in the Florida Coastal Everglades. Journal of Environmental Management 211:164- 176.

Egler, F. E. 1952. Southeast saline Everglades vegetation, Florida, and its management. Vegetation 3: 213-265.

Ewe, S. M. L., E. E. Gaiser, D. L. Childers, D. Iwaniec, V. H. Rivera-Monroy, and R. R. Twilley. 2006. Spatial and temporal patterns of aboveground net primary productivity along two freshwater-estuarine transects in the Florida Coastal Everglades. Hydrobiologia 569:459-474.

Feller, I. C., D. F. Whigham, J. P. O'Neill, and K. L. McKee. 1999. Effects of nutrient enrichment on within-stand cycling in a mangrove forest. Ecology 80:2193-2205.

Flower, H., M. Rains, and C. Fitz. 2017a. Visioning the Future: Scenarios Modeling of the Florida Coastal Everglades. Environmental Management 60:989-1009.

Flower, H., M. Rains, D. Lewis, J. Z. Zhang, and R. Price. 2017b. Saltwater intrusion as potential driver of phosphorus release from limestone bedrock in a coastal aquifer. Estuarine Coastal and Shelf Science 184:166-176.

Gleeson, S. K., and D. Tilman. 1992. Plant allocation and the multiple limitation hypothesis. American Naturalist 139:1322-1343. 
Griscom, B. W., J. Adams, P. W. Ellis, R. A. Houghton, G. Lomax, D. A. Miteva, W. H. Schlesinger, D. Shoch, J. V. Siikamaki, P. Smith, P. Woodbury, C. Zganjar, A. Blackman, J. Campari, R. T. Conant, C. Delgado, P. Elias, T. Gopalakrishna, M. R. Hamsik, M. Herrero, J. Kiesecker, E. Landis, L. Laestadius, S. M. Leavitt, S. Minnemeyer, S. Polasky, P. Potapov, F. E. Putz, J. Sanderman, M. Silvius, E. Wollenberg, and J. Fargione. 2017. Natural climate solutions. Proceedings of the National Academy of Sciences of the United States of America 114:11645-11650.

Haigh, I. D., T. Wahl, E. J. Rohling, R. M. Price, C. B. Pattiaratchi, F. M. Calafat, and S. Dangendorf. 2014. Timescales for detecting a significant acceleration in sea level rise. Nature Communications 5:11.

Herbert, E. R., P. Boon, A. J. Burgin, S. C. Neubauer, R. B. Franklin, M. Ardon, K. N. Hopfensperger, L. P. M. Lamers, and P. Gell. 2015. A global perspective on wetland salinization: ecological consequences of a growing threat to freshwater wetlands. Ecosphere 6:43.

Huston, M. A. 1997. Landscape patterns: gradients and zonation. University Press of Florida, Gainesville, Florida.

Ise, T., Dunn, A. L., Wofsy, S. C. \& Moorcroft, P. R. 2008. High sensitivity of peat decomposition to climate change through water-table feedback. Nature Geoscience 1: 763-766.

Karam A. 1993. Chemical properties of organic soils. In: Carter MR, for Canadian Society of Soil Science, Eds. Soil sampling and methods of analysis. London: Lewis Publishers. Pp 459- 71.

Kirwan, M. L., and J. P. Megonigal. 2013. Tidal wetland stability in the face of human impacts and sea-level rise. Nature 504:53-60.

Kirwan, M. L., S. Temmerman, E. E. Skeehan, G. R. Guntenspergen, and S. Fagherazzi. 2016. Overestimation of marsh vulnerability to sea level rise. Nature Climate Change 6:253-260.

Krauss, K. W., J. A. Duberstein, T. W. Doyle, W. H. Conner, R. H. Day, L. W. Inabinette, and J. L. Whitbeck. 2009. Site condition, structure, and growth of baldcypress along tidal/non-tidal salinity gradients. Wetlands 29:505-519.

Macek, P., and E. Rejmankova. 2007. Response of emergent macrophytes to experimental nutrient and salinity additions. Functional Ecology 21:478-488.

McKee, K. L., D. R. Cahoon, and I. C. Feller. 2007. Caribbean mangroves adjust to rising sea level through biotic controls on change in soil elevation. Global Ecology and Biogeography 16:545-556. 
McLeod, E., G. L. Chmura, S. Bouillon, R. Salm, M. Bjork, C. M. Duarte, C. E. Lovelock, W. H. Schlesinger, and B. R. Silliman. 2011. A blueprint for blue carbon: toward an improved understanding of the role of vegetated coastal habitats in sequestering CO2. Frontiers in Ecology and the Environment 9:552560 .

McVoy, C., P. W. Said, J. Obeysekera, J. A. VanArman, and T. W. Drescher. 2011. Landscapes and hydrology of the predrainage Everglades. University Press of Florida, Gainesville, Florida.

Morris, J. T., D. C. Barber, J. C. Callaway, R. Chambers, S. C. Hagen, C. S. Hopkinson, B. J. Johnson, P. Megonigal, S. C. Neubauer, T. Troxler, and C. Wigand. 2016. Contributions of organic and inorganic matter to sediment volume and accretion in tidal wetlands at steady state. Earths Future 4:110-121.

Nerem, R. S., B. D. Beckley, J. T. Fasullo, B. D. Hamlington, D. Masters, and G. T. Mitchum. 2018. Climate-change-driven accelerated sea-level rise detected in the altimeter era. Proceedings of the National Academy of Sciences of the United States of America 115:2022-2025.

Neubauer, S. C. 2008. Contributions of mineral and organic components to tidal freshwater marsh accretion. Estuarine Coastal and Shelf Science 78:78-88.

Neubauer, S. C. 2013. Ecosystem responses of a tidal freshwater marsh experiencing saltwater intrusion and altered hydrology. Estuaries and Coasts 36:491-507.

Nyman, J. A., R. D. Delaune, H. H. Roberts, and W. H. Patrick. 1993. Relatinship between vegeation and soil formation in a rapidly submerging coastal marsh. Marine Ecology Progress Series 96:269-279.

Nyman, J. A., R. J. Walters, R. D. Delaune, and W. H. Patrick. 2006. Marsh vertical accretion via vegetative growth. Estuarine Coastal and Shelf Science 69:370-380.

Price, R. M., M. R. Savabi, J. L. Jolicoeur, and S. Roy. 2010. Adsorption and desorption of phosphate on limestone in experiments simulating seawater intrusion. Applied Geochemistry 25:1085-1091.

Qualls, R. G., and C. J. Richardson. 2008. Carbon cycling and dissolved organic matter export in the northern Everglades.in C. J. Richardson, editor. The Everglades Experiments, Ecological Studies. Springer, New York.

Qualls, R. G., and C. J. Richardson. 2000. Phosphorus enrichment affects litter decomposition, immobilization, and soil microbial phosphorus in wetland mesocosms. Soil Science Society of America Journal 64:799-808. 
Ross, M. S., J. F. Meeder, J. P. Sah, P. L. Ruiz, and G. J. Telesnicki. 2000. The Southeast Saline Everglades revisited: 50 years of coastal vegetation change. Journal of Vegetation Science 11:101-112.

Sandoval, E., R. M. Price, D. Whitman, and A. M. Melesse. 2016. Long-term (11 years) study of water balance, flushing times and water chemistry of a coastal wetland undergoing restoration, Everglades, Florida, USA. Catena 144:74-83.

Sklar, F. H., M. J. Chimney, S. Newman, P. McCormick, D. Gawlik, S. L. Miao, C. McVoy, W. Said, J. Newman, C. Coronado, G. Crozier, M. Korvela, and K. Rutchey. 2005. The ecological-societal underpinnings of Everglades restoration. Frontiers in Ecology and the Environment 3:161-169.

Tilman, D. 1985. The resource-ratio hypotheis of plant sucession. American Naturalist 125:827-852.

Titus, J. G., and C. Richman. 2001. Maps of lands vulnerable to sea level rise: modeled elevations along the US Atlantic and Gulf coasts. Climate Research 18:205-228.

Trenberth, K. E., A. G. Dai, G. van der Schrier, P. D. Jones, J. Barichivich, K. R. Briffa, and J. Sheffield. 2014. Global warming and changes in drought. Nature Climate Change 4:17-22.

Troxler, T. G., D. L. Childers, and C. J. Madden. 2014. Drivers of Decadal-Scale Change in Southern Everglades Wetland Macrophyte Communities of the Coastal Ecotone. Wetlands 34:S81-S90.

Wdowinski, S., R. Bray, B. P. Kirtman, and Z. H. Wu. 2016. Increasing flooding hazard in coastal communities due to rising sea level: Case study of Miami Beach, Florida. Ocean \& Coastal Management 126:1-8.

Weston, N. B., M. A. Vile, S. C. Neubauer, and D. J. Velinsky. 2011. Accelerated microbial organic matter mineralization following salt-water intrusion into tidal freshwater marsh soils. Biogeochemistry 102:135-151.

White, E., and D. Kaplan. 2017. Restore or retreat? saltwater intrusion and water management in coastal wetlands. Ecosystem Health and Sustainability 3.

Woodroffe, C. D. 1990. The impact of sea-level rise on mangrove shorelines. Progress in Physical Geography 14:483-520. 
Table 1. Soil OC change in response to salinity and phosphorus addition in a freshwater marsh mesocosm experiment. Mean and standard error for each treatment type ( $\mathrm{n}=6$ per treatment). The driver and direction of effects and significant $\mathrm{P}-\mathrm{values}$ from 2-way analysis of variance (ANOVA) included.

\begin{tabular}{|c|c|c|c|c|c|c|}
\hline & \multicolumn{3}{|c|}{ Freshwater Marsh Mean (SE) } & \multirow[b]{2}{*}{ Salt $+\mathrm{P}$} & \multirow{2}{*}{$\begin{array}{l}\text { Significant } \\
\text { Effects }\end{array}$} & \multirow{2}{*}{$\begin{array}{c}P \text { - } \\
\text { values }\end{array}$} \\
\hline & Fresh & Fresh $+\mathrm{P}$ & Salt & & & \\
\hline $\begin{array}{l}\text { Root ingrowth } \\
\left(\mathrm{C} \mathrm{m}^{-2} \mathrm{y}^{-1}\right)\end{array}$ & $\begin{array}{c}81.34 \\
(13.41)\end{array}$ & $\begin{array}{l}179.28 \\
(37.3)\end{array}$ & $\begin{array}{c}49.07 \\
(13.77)\end{array}$ & $\begin{array}{l}126.53 \\
(33.43)\end{array}$ & $\mathrm{P}(+)$ & 0.004 \\
\hline $\begin{array}{l}\text { Root biomass } \\
\left(\mathrm{C} \mathrm{m}^{-2}\right)\end{array}$ & $\begin{array}{c}456 \\
(147.4)\end{array}$ & $\begin{array}{c}599.1 \\
(121.8)\end{array}$ & $\begin{array}{l}252.4 \\
(65.7)\end{array}$ & $\begin{array}{l}301.2 \\
(57.5)\end{array}$ & Salinity (-) & 0.03 \\
\hline $\begin{array}{l}\text { Leaf litter breakdown } \\
\text { (Prop AFDM, } 1 \text { year) }\end{array}$ & $\begin{array}{c}0.61 \\
(0.01)\end{array}$ & $\begin{array}{c}0.51 \\
(0.03)\end{array}$ & $\begin{array}{c}0.61 \\
(0.02)\end{array}$ & $\begin{array}{c}0.49 \\
(0.03)\end{array}$ & $\mathrm{P}(+)$ & 0.0003 \\
\hline $\begin{array}{l}\text { Root breakdown } \\
(0-7.5 \mathrm{~cm} \text {, Prop } \\
\text { AFDM, 1 year) }\end{array}$ & $\begin{array}{c}0.74 \\
(0.02)\end{array}$ & $\begin{array}{c}0.68 \\
(0.01)\end{array}$ & $\begin{array}{c}0.74 \\
(0.01)\end{array}$ & $\begin{array}{c}0.66 \\
(0.02)\end{array}$ & $\mathrm{P}(+)$ & 0.002 \\
\hline $\begin{array}{l}\text { Root breakdown } \\
\text { ( } 7.5-15 \mathrm{~cm} \text {, Prop } \\
\text { AFDM, } 1 \text { year) }\end{array}$ & $\begin{array}{c}0.74 \\
(0.02)\end{array}$ & $\begin{array}{c}0.65 \\
(0.02)\end{array}$ & $\begin{array}{c}0.77 \\
(0.01)\end{array}$ & $\begin{array}{c}0.74 \\
(0.02)\end{array}$ & $\mathrm{P}(+)$ & 0.007 \\
\hline $\begin{array}{l}\text { Elevation change } \\
\left(\mathrm{cm} \mathrm{y}^{-1}\right)\end{array}$ & $\begin{array}{l}-0.04 \\
(0.83)\end{array}$ & $\begin{array}{c}0.88 \\
(0.63)\end{array}$ & $\begin{array}{l}-2.75 \\
(0.51)\end{array}$ & $\begin{array}{l}-2.29 \\
(0.38)\end{array}$ & Salinity (-) & 0.0001 \\
\hline
\end{tabular}


Table 2. Soil OC change in response to salinity addition and increased inundation in a brackish marsh mesocosm experiment.

Mean and standard error for each treatment type $(n=6$ per treatment $)$. The driver and direction of effects and significant $\mathrm{P}-\mathrm{values}$ from 2-way ANOVAs included.

\begin{tabular}{|c|c|c|c|c|c|c|}
\hline & \multicolumn{4}{|c|}{ Brackish Marsh Mean (SE) } & \multirow{2}{*}{$\begin{array}{l}\text { Significant } \\
\text { Effects }\end{array}$} & \multirow{2}{*}{$\begin{array}{c}P- \\
\text { values }\end{array}$} \\
\hline & $\begin{array}{l}\text { Ambient } \\
\text { Exposed }\end{array}$ & $\begin{array}{c}\text { Ambient } \\
\text { Submerged }\end{array}$ & $\begin{array}{c}\text { Salt } \\
\text { Exposed }\end{array}$ & $\begin{array}{c}\text { Salt } \\
\text { Submerged }\end{array}$ & & \\
\hline $\begin{array}{l}\text { Root Ingrowth } \\
\left(\mathrm{OC} \mathrm{m}^{-2} \mathrm{y}^{-1}\right)\end{array}$ & $\begin{array}{c}67.8 \\
(10.2)\end{array}$ & $\begin{array}{c}69.6 \\
(18.7)\end{array}$ & $\begin{array}{l}21.0 \\
(8.9)\end{array}$ & $\begin{array}{l}20.2 \\
(5.6)\end{array}$ & Salinity (-) & 0.02 \\
\hline 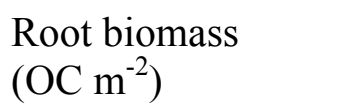 & $\begin{array}{c}449.6 \\
(104.2)\end{array}$ & $\begin{array}{c}384.3 \\
(39.82)\end{array}$ & $\begin{array}{l}252.36 \\
(57.35)\end{array}$ & $\begin{array}{l}219.06 \\
(24.34)\end{array}$ & Salinity (-) & 0.03 \\
\hline $\begin{array}{l}\text { Leaf proportion OC } \\
\text { remaining }(361 \mathrm{~d})\end{array}$ & $\begin{array}{c}0.55 \\
(0.05)\end{array}$ & $\begin{array}{c}0.44 \\
(0.06)\end{array}$ & $\begin{array}{c}0.6 \\
(0.05)\end{array}$ & $\begin{array}{c}0.43 \\
(0.07)\end{array}$ & NA & \\
\hline $\begin{array}{l}\text { Root OC proportion } \\
\text { remaining } \\
(361 \mathrm{~d}, 0-15 \mathrm{~cm})\end{array}$ & $\begin{array}{c}0.76 \\
(0.007)\end{array}$ & $\begin{array}{c}0.74 \\
(0.007)\end{array}$ & $\begin{array}{c}0.75 \\
(0.007)\end{array}$ & $\begin{array}{c}0.72 \\
(0.007)\end{array}$ & Salinity $(+)$ & 0.02 \\
\hline $\begin{array}{l}\text { Root OC proportion } \\
\text { remaining } \\
(361 \mathrm{~d}, 15-30 \mathrm{~cm})\end{array}$ & $\begin{array}{c}0.72 \\
(0.005)\end{array}$ & $\begin{array}{c}0.74 \\
(0.011)\end{array}$ & $\begin{array}{c}0.71 \\
(0.007)\end{array}$ & $\begin{array}{c}0.74 \\
(0.011)\end{array}$ & $\begin{array}{c}\text { Inundation } \\
(-)\end{array}$ & 0.03 \\
\hline $\begin{array}{l}\text { Elevation change } \\
\left(\mathrm{cm} \mathrm{y}^{-1}\right)\end{array}$ & $\begin{array}{l}-0.46 \\
(0.28)\end{array}$ & $\begin{array}{l}-0.75 \\
(0.22)\end{array}$ & $\begin{array}{l}-1.29 \\
(0.24)\end{array}$ & $\begin{array}{l}-0.58 \\
(0.26)\end{array}$ & NA & \\
\hline
\end{tabular}


Table 3. Decomposing organic matter stoichiometry in the freshwater marsh mesocosm experiment after 361 days $(n=6$ per treatment). Average litter and root nutrient concentration and standard error $(\% \mathrm{C}, \% \mathrm{~N}, \% \mathrm{P})$ and molar nutrient ratios $(\mathrm{C}: \mathrm{N}, \mathrm{C}: \mathrm{P}, \mathrm{N}: \mathrm{P}$. For each treatment type (Fresh, Fresh $+P$, Salt, Salt $+P), n=6$.

\begin{tabular}{|c|c|c|c|c|}
\hline & Fresh & Fresh $+\mathrm{P}$ & Salt & Salt + P \\
\hline \multicolumn{5}{|c|}{ Leaf litter } \\
\hline$\% \mathrm{C}$ & $0.88(0.04)$ & $0.81(0.04)$ & $0.81(0.03)$ & $0.72(0.06)$ \\
\hline$\% \mathrm{~N}$ & $43.82(0.30)$ & $44.48(0.12)$ & $42.91(0.58)$ & $42.42(0.19)$ \\
\hline$\% \mathrm{P}$ & $0.05(0.004)$ & $0.16(0.031)$ & $0.05(0.005)$ & $0.17(0.030)$ \\
\hline $\mathrm{C}: \mathrm{N}$ & $58(3)$ & $65(3)$ & $62(2)$ & $71(5)$ \\
\hline $\mathrm{C}: \mathrm{P}$ & $2248(156)$ & $838(123)$ & $2504(318)$ & $716(106)$ \\
\hline $\mathrm{N}: \mathrm{P}$ & $39(4)$ & $13(2)$ & $40(4)$ & $10(1)$ \\
\hline \multicolumn{5}{|c|}{$\operatorname{Roots}(0-7.5 \mathrm{~cm})$} \\
\hline$\% \mathrm{C}$ & $1.2(0.11)$ & $1.11(0.08)$ & $1.23(0.13)$ & $1.17(0.04)$ \\
\hline$\% \mathrm{~N}$ & $43.96(0.63)$ & $44.88(0.31)$ & $43.41(0.32)$ & $43.121(0.544)$ \\
\hline$\% \mathrm{P}$ & $0.14(0.02)$ & $0.14(0.01)$ & $0.14(0.02)$ & $0.158(0.01)$ \\
\hline $\mathrm{C}: \mathrm{N}$ & $\begin{array}{l}44.73(4.39) \\
946.189\end{array}$ & $\begin{array}{l}48.15(3.21) \\
867.829\end{array}$ & $43.15(4.05)$ & $43.26(1.6)$ \\
\hline $\mathrm{C}: \mathrm{P}$ & $(139.35)$ & $(73.82)$ & $864.79(87.75)$ & $726.99(87.75)$ \\
\hline $\mathrm{N}: \mathrm{P}$ & $20.68(1.44)$ & $17.94(0.51)$ & $20.02(0.51)$ & $16.72(1.09)$ \\
\hline \multicolumn{5}{|c|}{ Roots $(7.5-15 \mathrm{~cm})$} \\
\hline$\% \mathrm{C}$ & $1.19(0.13)$ & $1.03(0.04)$ & $1.00(0.073)$ & $1.131(0.01)$ \\
\hline$\% \mathrm{~N}$ & $44.57(0.22)$ & $44.09(0.56$ & $43.21(0.25)$ & $42.66(0.50)$ \\
\hline$\% \mathrm{P}$ & $0.130(0.021)$ & $0.133(0.011)$ & $0.113(0.003)$ & $0.133(0.008)$ \\
\hline $\mathrm{C}: \mathrm{N}$ & $46(5)$ & $51(2)$ & $52(4)$ & $46(4)$ \\
\hline $\mathrm{C}: \mathrm{P}$ & $1000(142)$ & $886(87)$ & $993(30)$ & $844(46)$ \\
\hline$N: P$ & $21(1)$ & $18(2)$ & $20(1)$ & $19(2)$ \\
\hline
\end{tabular}




\section{Figure Legends}

Figure 1. Soil organic carbon (OC) stocks and flux rates in response to elevated salinity and phosphorus additions in the freshwater marsh mesocosm experiment. A. Rates of root productivity over $361 \mathrm{~d}$, normalized to represent grams OC $\mathrm{m}^{-2} \mathrm{y}^{-1}(0-15 \mathrm{~cm})$. B. Living root biomass, normalized to represent grams $\mathrm{OC} \mathrm{m}^{-2}(0-15 \mathrm{~cm})$. C. Root breakdown rates in surface soil as proportion of ash-free dry mass (AFDM) remaining after 1 year (0-7.5 $\mathrm{cm})$. D. Root breakdown rates in deeper soil as proportion of AFDM remaining after 1 year $(7.5-15 \mathrm{~cm})$. E. Litter breakdown rates on the soil surface as proportion AFDM remaining after 1 year. F. Changes in soil elevation $(\mathrm{cm})$ after 1 year measured from fixed benchmarks. Letters indicate significant differences among treatments using twoway analysis of variance and Tukey's honest significant difference test $(P<0.05)$.

Figure 2. Litter breakdown and elevation change through time in the freshwater marsh mesocosm experiment. A. Salinity decreased soil elevation over the course of $361 \mathrm{~d}$. Salinity caused a rapid elevation loss between 65 and 166 days, after which elevations remained similar $(P<0.05)$. B. There was no difference in proportion leaf litter AFDM remaining after $80 \mathrm{~d}$, but Fresh $+\mathrm{P}$ and Fresh became significantly different after $166 \mathrm{~d}$, and all $\mathrm{P}$ treatments broke down faster after 267 and $361 \mathrm{~d}(P<0.01)$.

Figure 3. Soil organic carbon (OC) stocks and flux rates in response to elevated salinity and inundation in the brackish marsh mesocosm experiment. A. Rates of root productivity over $361 \mathrm{~d}$, normalized to represent grams OC $\mathrm{m}^{-2} \mathrm{y}^{-1}(0-15 \mathrm{~cm})$. B. Living root biomass, normalized to represent grams $\mathrm{OC} \mathrm{m}^{-2}(0-15 \mathrm{~cm})$. C. Root breakdown rates 
in surface soil as proportion of ash-free dry mass (AFDM) remaining after 1 y $(0-7.5 \mathrm{~cm})$. D. Root breakdown rates in deeper soil as proportion of AFDM remaining after 1 year (7.5- $15 \mathrm{~cm})$. E. Litter breakdown rates on the soil surface as proportion AFDM remaining after $1 \mathrm{y}$. F. Changes in soil elevation $(\mathrm{cm})$ after $361 \mathrm{~d}$ normalized to represent one year measured from fixed benchmarks. Letters indicate significant differences among treatments using analysis of variance and Tukey's honest significant difference $(P<$ $0.05)$. 
Figure 1.
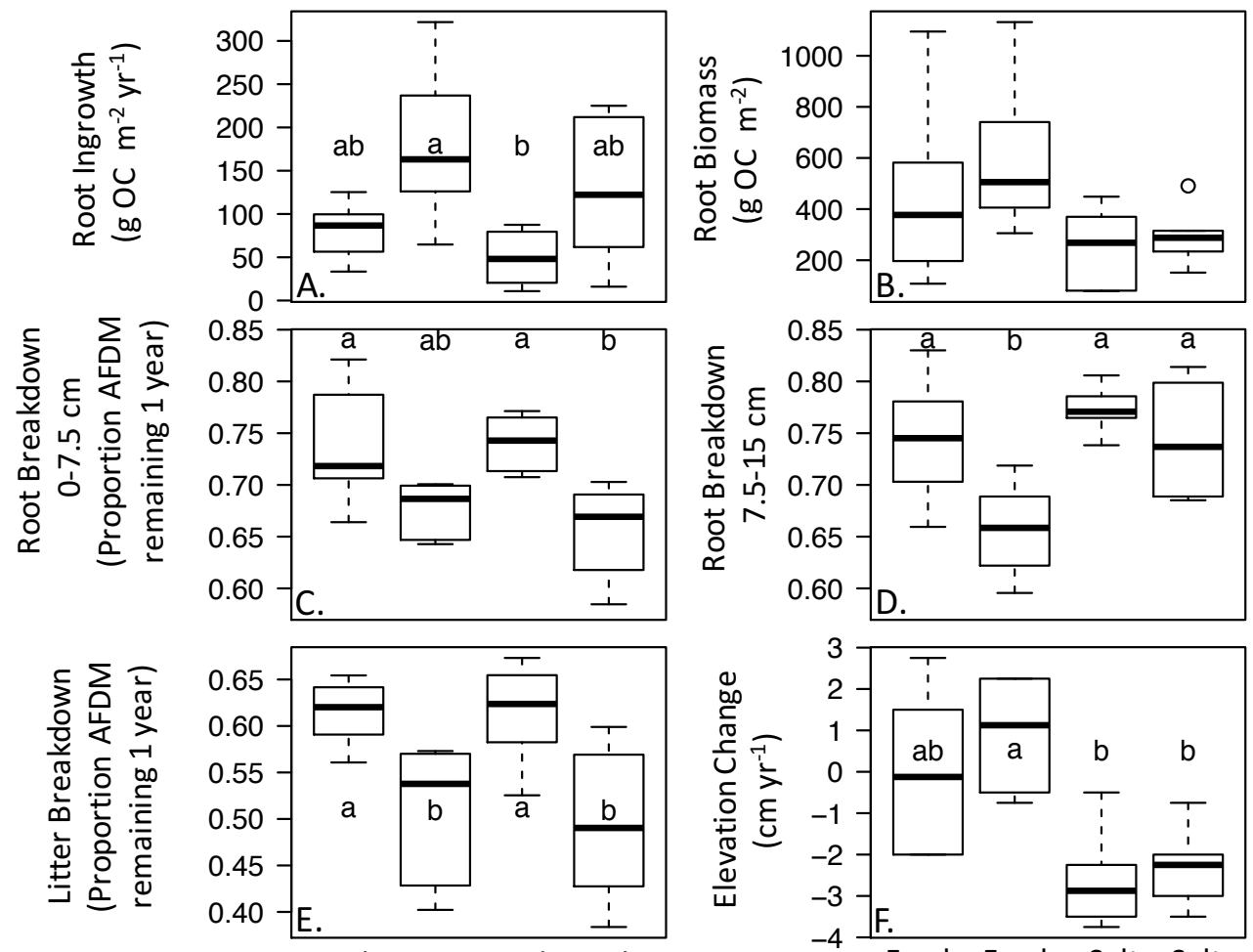

Salinity :

Phosphorus:

Fresh Fresh Salt Salt

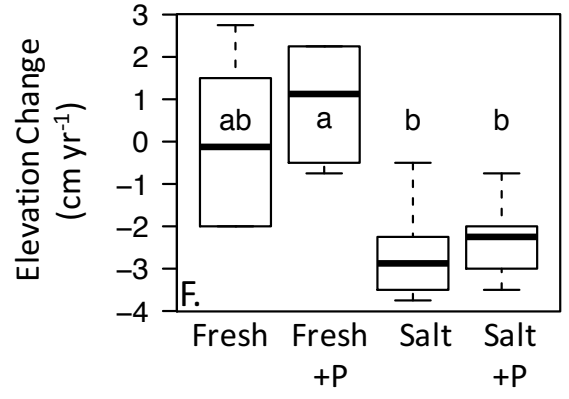


Figure 2.
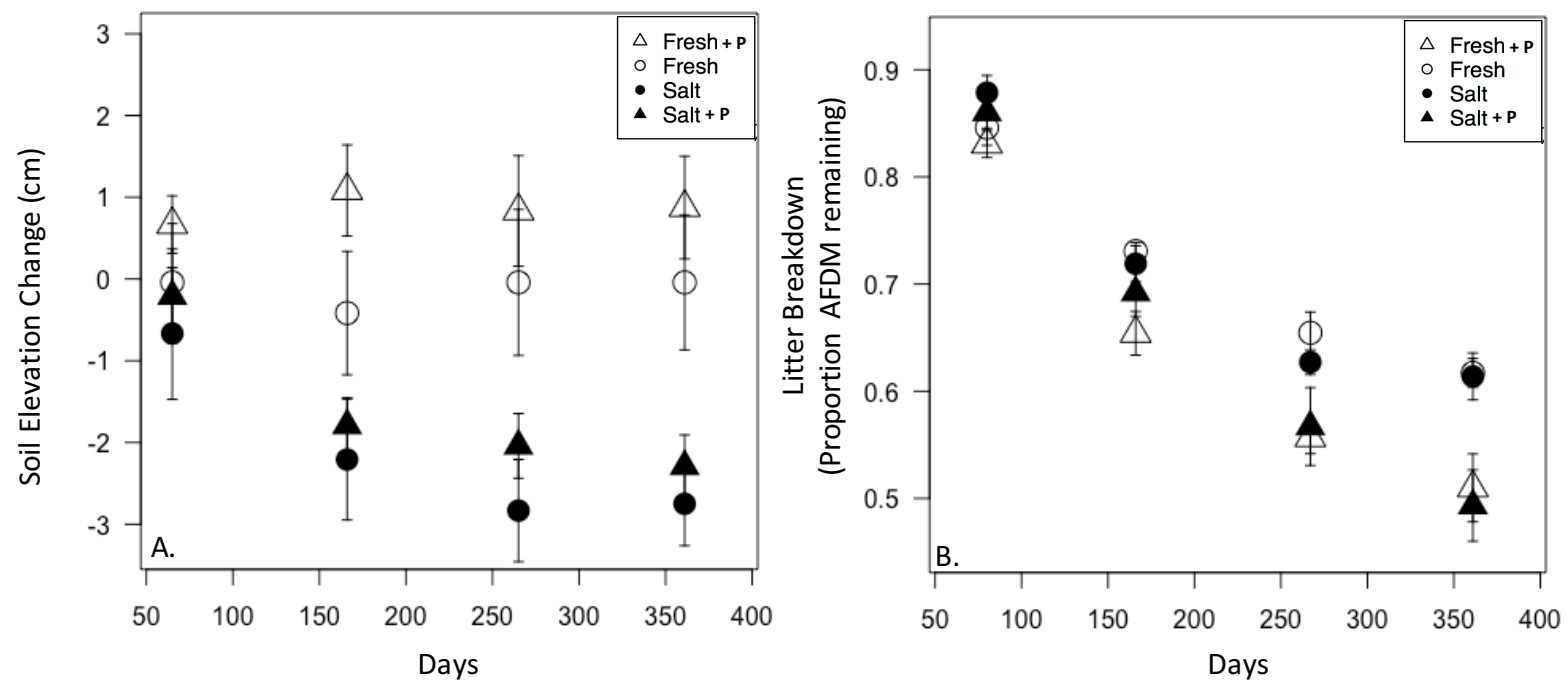
Figure 3.
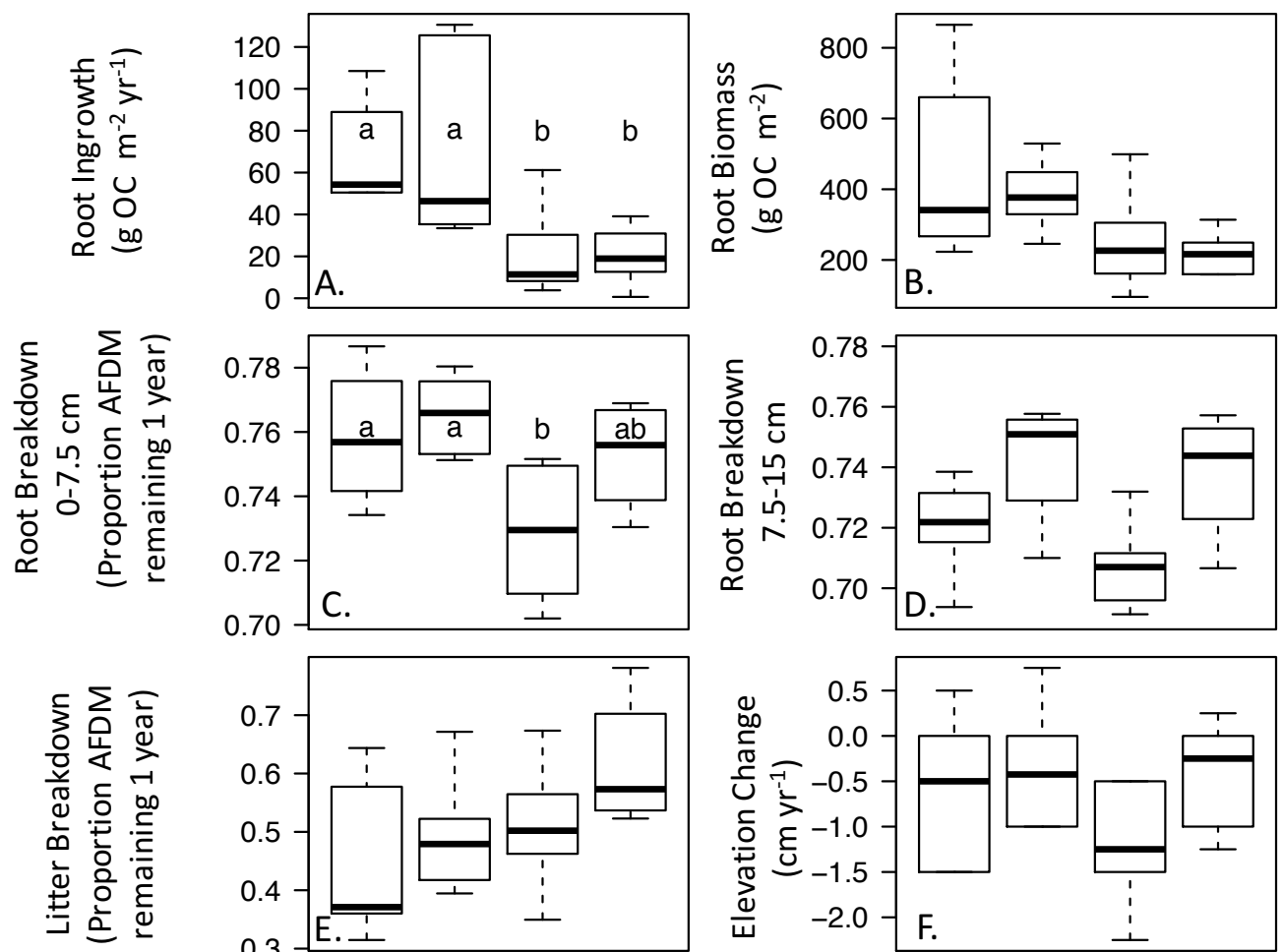

Salinity: Inundation:
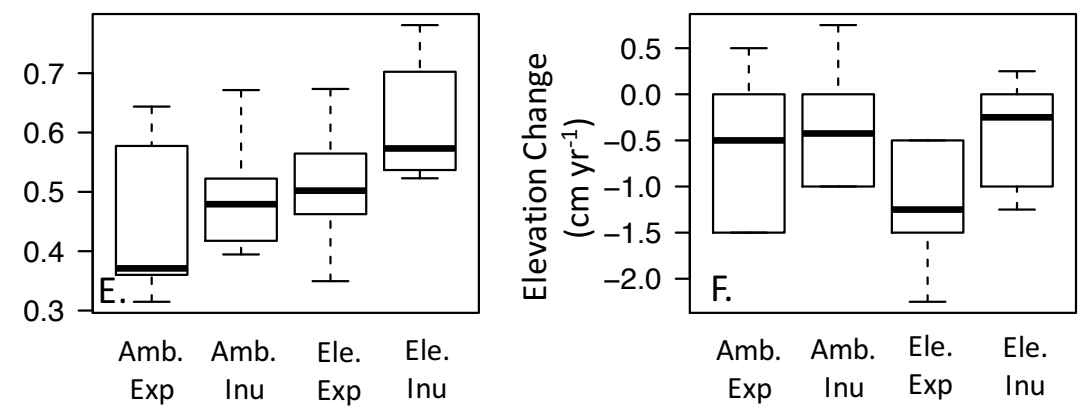


\section{CHAPTER II \\ MANGROVES INCREASE ORGANIC CARBON STORAGE IN AN \\ EXPERIMENTAL MARSH-MANGROVE GRADIENT DESPITE REDUCED \\ MARINE SUBSIDIES}


Running Head: Coastal vegetation shifts alter organic carbon storage at multiple spatial scales

Title: Mangroves increase organic carbon storage in an experimental marsh-mangrove gradient despite reduced marine subsidies

Authors: Sean P. Charles, John S. Kominoski, Anna R. Armitage, Hongyu Guo, Carolyn A. Weaver and Steven C. Pennings

\section{Key Words}

Vegetation state change, mangrove encroachment, Gulf of Mexico, carbon cycling 


\begin{abstract}
Despite overall global declines, mangroves are expanding into and within many subtropical wetlands as climate change reduces extreme cold events. Coastal wetlands are globally important $\mathrm{CO}_{2}$ sinks, yet the effects of shifts in mangrove cover on OC storage remains uncertain. To quantify the impacts of shifts in mangrove cover, we removed mangroves (Avicennia germinans) from $3 \cdot 3 \mathrm{~m}$ patches and allowed marsh vegetation to recolonize (primarily Batis maritima) to create a gradient of mangrove cover within 24 . $42 \mathrm{~m}$ plots. Mangroves increased OC stocks in aboveground (1630\%) and belowground (61\%) biomass and in soil OC (30\%) at the patch-scale. At the plot-scale, above and belowground biomass increased linearly with mangrove cover, but there was no impact on soil OC. We found no impact of vegetation dynamics on root ingrowth. After 11 months, plot-scale mangrove cover reduced surface OC accretion however, after 22 months, accretion was $54 \%$ higher in mangrove patches and there was no relationship to plot-scale mangrove cover. Mangrove (A. germinans) organic matter had much slower breakdown rates $(k)$ for leaf litter $(1000 \%)$ and roots $(35 \%)$ than organic matter from the dominant marsh vegetation (B. maritima). Additionally, patch mangrove cover created shade to reduce average soil temperature $1.4^{\circ} \mathrm{C}$, decreasing aboveground breakdown of cellulose at the patch-scale (30\%) and wood and cellulose at the plot-scale. Mangrove patches had $41 \%$ higher belowground wood $k$ in shallow soil $(0-15 \mathrm{~cm})$, but vegetation did not impact wood $k$ in deeper soil $(15-30 \mathrm{~cm})$. In our study area, mangrove vegetation increased OC storage through accumulating biomass and reducing $k$ of both autochthonous and standard organic matter. However, there was no plot level increase in soil OC due to tradeoffs above and belowground. While mangroves enhanced root
\end{abstract}


biomass and produced recalcitrant $\mathrm{OM}$, they also prime breakdown of standard $\mathrm{OM}$ and reduce allochthonous subsidies and surface accretion compared to marsh vegetation. Our results illustrate the potential of mangroves to increase OC storage under certain scenarios, but that the impact on OC storage may have different impacts on OC storage under different ecosystem conditions.

Key Words: ecosystem function, carbon storage, regime shift, ecosystem vulnerability, sea level rise

\section{INTRODUCTION}

Increasing global mean temperature is driving changes in species distributions, with many taxonomic groups shifting their ranges to higher altitudes and latitudes (Chen et al. 2011). Shifts in dominant vegetation can impact ecosystem structure and function (Van Auken 2000; Kominoski et al. 2013), but many of the likely impacts resulting from vegetation shifts remain uncertain. In particular, shifts in tree species dominance can drastically alter ecosystem processes. Encroachment of woody trees is a widespread phenomenon that demonstrates how a shift in dominant species can impact ecosystem function, (e.g. altering organic matter sources, habitat, food webs, biogeochemistry and microclimate) (Van Auken 2000; D’Odorico et al. 2013; Guo et al. 2017).

Mangrove trees are woody species that dominate coastal wetlands of the tropics, and are likely to expand to higher latitudes as extreme cold events become less frequent (Cavanaugh et al. 2014; Saintillan et al. 2014). In particular, rapid transformations are underway in coastal wetlands along the U.S. Gulf of Mexico as mangroves displace marsh species (Osland et al. 2013; Osland et al. 2017) across a coastline at "very high" 
risk of submergence from sea-level rise (SLR) (Thieler and Hammar-Klose 2000). Mangrove expansion has been particularly dramatic in Texas, where mangrove cover increased 74\% between 1990 and 2010 (Armitage et al. 2015), yet the ecosystem impacts of these changes are largely unknown (Guo et al. 2017).

Coastal wetlands, given their small global area, provide a disproportionately high level of ecosystem services (Costanza et al. 2014; Barbieri et al. 2011), many of which rely on the storage of organic carbon (OC). Coastal wetlands store more OC per area than other ecosystems (Chmura et al. 2003; McLeod et al. 2011), providing a globally important feedback to climate change known as "blue carbon". Furthermore, at the local level, storage of OC and belowground biomass in the soil often drives wetland surface elevation change (Nyman et al. 2006; McKee et al. 2007; Neubauer 2008), allowing many coastal wetlands to increase their surface elevation to keep pace with SLR for thousands of years (Woodroffe et al. 1990; McKee et al. 2007) though this adaptation capacity may be diminished in light of rapidly increasing rates of sea level rise (Dangendorf et al. 2017).

Shifts in dominant plant communities may alter OC storage by changing the quantity and quality of autochthonous organic matter (Twilley et al. 1986), altering microclimate (Fierer et al. 2005; D’Odorico et al. 2013) and deposition of allochthonous organic matter (Fagherazzi et al. 2006). Coastal wetlands dominated by mangroves and marshes vary widely in their capacity to store OC, and globally there is no clear difference between average marsh and mangrove wetland OC storage rates (Chmura et al. 2003). In the context of climate change, however, transitions from one vegetation type to the other at a single location may have profound ecological implications. Even within 
regions, the impacts of vegetation shifts are uncertain. For example, along the northern range limit of mangroves in the United States, some studies have found similar soil carbon storage and sequestration rates between marshes and mangroves (Perry and Mendelssohn 2009; Henry and Twilley 2013; Doughty et al. 2015; McKee et al. 2017), while others have found profound differences (Osland et al. 2012; Bianchi et al. 2013; Comeaux et al. 2013). Determining the drivers of OC storage is important to manage and predict ecosystem vulnerability in a changing world.

Shifts in vegetation identity and proportion cover are likely to have complex, scale-dependent effects on ecosystem processes (Guo et al. 2017). In terrestrial systems, woody encroachment often leads to "resource islands" where shrubs increase small scale productivity by capturing resources (light, nutrients, sediment and water) at the expense of adjacent "interspaces" (Li et al. 2008), creating heterogeneity of structure and function across landscapes. Similarly, along the marsh to mangrove ecotone, mangrove expansion is likely to be patchy as habitat availability, propagule sources, disturbances and climate limit mangrove establishment (Sherrod and McMillan 1985; Osland et al. 2017). To truly understand the consequences of foundation plant shifts on OC stocks and fluxes, it is essential to understand the local and landscape-level effects of mangrove and marsh vegetation on OC stocks and fluxes.

We quantified the impacts of coastal wetland plant species identity (marsh versus mangrove) and percent cover on OC stocks (soil OC and biomass) and fluxes (rates of $\mathrm{OC}$ input as roots and surface accretion and breakdown rates of species specific and standard organic matter substrates). We manipulated vegetation identity in $(3 \cdot 3 \mathrm{~m})$ patches to create ten large plots that ranged from $0-100 \%$ mangrove cover. This 
experimental design allowed us to 1) manipulate vegetation cover in situ to isolate the impacts of the vegetation itself from the effects of site-specific abiotic conditions and 2) utilize a gradient of plot-scale mangrove and marsh cover to identify the scale- and density-dependence of OC stocks and fluxes in mixed mangrove and marsh communities. We hypothesized that 1) increasing mangrove cover would increase the storage of OC by decreasing breakdown rates (increasing recalcitrant organic matter production, decreasing soil temperature) and enhancing OC inputs (root productivity and surface deposition); and 2) effects on specific stocks and fluxes of OC would differ based on vegetation identity, cover and location across plots. Specifically, we predicted that plant biomass, root productivity and litter breakdown rates would largely be driven by patch-scale vegetation identity and surface accretion would be driven by plot-scale vegetation cover.

\section{METHODS}

\section{Experimental Sites}

Our field experiments took place on Harbor Island, Port Aransas, TX $\left(27.86^{\circ} \mathrm{N}\right.$, $\left.97.08^{\circ} \mathrm{W}\right)$. In 2012 , we created ten large plots $(24 \cdot 42 \mathrm{~m})$, extending from the Lydia Ann Channel into the wetland interior (Figure 1 supplementary material). Before manipulation, all plots had similar elevation, soil characteristics and vegetation communities dominated by black mangrove (Avicennia germinans) (Guo et al. 2017). Based on aerial photography, our research sites were dominated by mangroves in 1970 (Bianchi et al. 2013), but were primarily salt marsh earlier in the $20^{\text {th }}$ century.

Within plots, we removed mangroves from randomly selected $3 \cdot 3 \mathrm{~m}$ "patches" and allowed marsh vegetation (primarily Batis maritima) to recolonize for 18 months 
before conducting research described in this paper (Guo et al. 2017). Treatments were maintained throughout the experiment by removing mangrove seedlings that recruited in marsh patches, and annually clipping mangrove encroaching into marsh patches. Plots ranged from $0 \%$ to $100 \%$ mangrove cover $(0 \%, 11 \%, 22 \%, 33 \%, 44 \%, 55 \%, 66 \%, 77 \%$, $88 \%$ and $100 \%$ ) and were randomly distributed along the shoreline (Guo et al. 2017).

In each plot, we made measurements in four pairs of $3 \cdot 3 \mathrm{~m}$ patches of marsh and mangrove vegetation (except in the 0 and 100\% mangrove plots, in which all patches were either marsh or mangrove), including four patches within the coastal fringe (3-12 m from the coastal edge) and four patches within the marsh interior (18-36 $\mathrm{m}$ from the coastal edge). Fringe patches are in a zone characterized by taller mangroves $(\sim 2.5 \mathrm{~m})$, while interior patches were characterized by shorter ( $\sim 1 \mathrm{~m}$ tall) mangroves. For some variables we sampled a subset of plots as dictated by logistical constraints, but our sampling design always ensured a gradient of $0-100 \%$ mangrove cover.

\section{Microclimate}

We measured soil temperature (at $10 \mathrm{~cm}$ depth) in one patch per vegetation type located in the center of each plot $(n=18$ patches $)$. We calculated average soil temperature from November 2014 to November 2015, from hourly measurements with HOBO pendant data loggers (Onset Computer Corporation, Bourne, MA, USA).

We measured the proportion of photosynthetically active radiation (PAR) intercepted by aboveground vegetation during peak sunlight hours (1100 to 1300) seasonally in 2015 (January, March, June, August, November) in all patches $(n=80)$. We measured PAR with a LI-190 quantum sensor (LI-COR, Lincoln, NE, USA), and 
calculated interception by vegetation, by comparing PAR at the soil surface, with PAR above the plant canopy with the equation: light intercepted by vegetation $=1-$ soil surface PAR / PAR above canopy $\bullet 100$.

\section{Organic Carbon Standing Stocks}

We measured aboveground biomass in four plots $(0 \%, 33 \%, 66 \%$ and $100 \%$ mangrove cover) ( $n=32$ patches). In November 2015 we measured aboveground biomass in marsh patches by clipping all aboveground vegetation within randomly placed $0.25 \mathrm{~m}^{2}$ quadrats. In mangrove patches we measured all individual mangrove plants within $3 \cdot 3 \mathrm{~m}$ patches and calculated biomass using allometric relationships reported by Osland et al. (2012).

We measured marsh and mangrove belowground biomass in six of the ten plots $(0 \%, 22 \%, 33 \%, 55 \%, 66 \%$, and $100 \%)(n=48$ patches $)$. In each patch, we took duplicate $(7 \mathrm{~cm}$ diameter, $30 \mathrm{~cm}$ depth) root cores, separated them into $0-15 \mathrm{~cm}$ and $15-$ $30 \mathrm{~cm}$ sections and transported them on ice to the laboratory ( $n=96$ cores). Roots were separated from sediment by rinsing through a 1-mm mesh sieve. Live roots were identified based on color, texture and pliability and collected for biomass measurements. In addition, we measured surface soil OC content by collecting duplicate $(7 \mathrm{~cm}$ diameter, $15 \mathrm{~cm}$ depth) soil cores in all ten plots ( $n=80$ patches, $n=160$ cores). We chose to collect duplicate root and soil cores to account for belowground variability, and report averages from within each patch.

\section{Organic Matter Inputs}


We measured root in-growth in six of ten plots $(0 \%, 22 \%, 33 \%, 55 \%, 66 \%$, and $100 \%)(n=48$ patches) using the ingrowth core method (Vogt et al. 1998). We created ingrowth bags from 3-mm flexible nylon mesh $(30 \mathrm{~cm}$ long, $5 \mathrm{~cm}$ diameter), filled them with a mixture of commercial peat moss and sand (mixed to $7 \%$ OC content to approximate local soil type). We established duplicate in-growth bags per patch ( $n=96$ total) and incubated them for one year (November 2014 to November 2015). After bags were retrieved from the field, samples were rinsed over a 1-mm sieve, and roots were separated from soil material. We then measured dry mass and ash free dry mass as described above.

We measured surface sediment and OC accretion above $0.5 \mathrm{~m}^{2}$ feldspar marker horizons (Cahoon and Turner 1989) that we established within all ten plots ( $n=80$ total) in June 2013. We measured accretion after 11 and 22 months by taking 5-cm diameter cores and measured depth to the feldspar marker horizon. To calculate OC accretion ( $\mathrm{g}$ OC $\mathrm{m}^{2} \mathrm{y}^{-1}$ ), we took 5 -cm diameter soil cores adjacent to accretion marker horizons, sectioned them to the depth of accretion, and measured bulk density and percent OC of newly-accreted material. We calculated rates of $\mathrm{OC}$ accretion with the equation $O C$ Accretion $\left(g\right.$ OC $\left.m^{-2} y^{-1}\right)=$ mass of accretion $\bullet$ OC content.

\section{Organic Matter Breakdown}

We measured breakdown rates of species-specific autochthonous leaf litter from marsh and mangrove vegetation. We incubated senescent litter from the dominant marsh (B. maritima) and mangrove (A. germinans) vegetation on the soil surface beginning November 20, 2014 for 111, 208, 260 and $361 \mathrm{~d}$. We filled 1-mm nylon mesh bags with 
$\sim 3$ grams of air-dried leaf litter. We incubated mangrove litter in all ten plots $(n=80$ patches). Due to the difficulty collecting senescent marsh litter, we measured B. maritima litter in four of the ten plots $(0 \%, 22 \%, 44 \%$, and $100 \%$ mangrove cover) during the same time period $(n=32$ patches $)$.

We measured root breakdown rates in seven plots $(0 \%, 22 \%, 33 \%, 55 \%, 66 \%$, $77 \%$, and $100 \%$ mangrove cover; $n=56$ patches) in duplicate root bags from each vegetation type in their native patch type over the course of 362 days ( $n=112$ total). Root breakdown bags were separated into 0-15 and 15-30 cm depths and filled with $2 \mathrm{~g}$ of roots from either mangrove (A. germinans) or marsh (B. maritima) and inserted vertically into the soil column to capture two distinct depth profiles.

Labile (cellulose) and recalcitrant (wood oak veneers) organic matter were incubated on the soil surface in all ten plots over $360 \mathrm{~d}$ starting in November 2013. Replicates of each substrate type were retrieved from each sampling location after 14, 50, 106, 208 and 360 d. Additionally, we measured belowground breakdown of wood standard substrates after $362 \mathrm{~d}$ at two depths $(0-15$ and $15-30 \mathrm{~cm})$, starting November 2014.

We returned all samples to the laboratory on ice, rinsed them of sediment, and calculated dry mass and AFDM as described above. We estimated breakdown rate, $k$, using a linear regression of the ln-transformed fraction of AFDM remaining vs. time (negative exponential model; sensu Benfield 2006). The specific model used is $M_{t}=M_{0}$ - $e^{-k t}$, where $M_{0}$ is the initial litter mass, $M_{t}$ is the litter mass on a given sampling day, $t$ is time (days of incubation). 


\section{Organic Matter processing}

We dried all organic matter at $60^{\circ} \mathrm{C}$ until mass stabilized to determine dry mass. Samples were then ground using an 8000-D ball mill (Spex SamplePrep, Metuchen, New Jersey, USA). Proportion organic matter was calculated from ash-free dry mass (AFDM) as loss on ignition in a muffle furnace at $550^{\circ} \mathrm{C}$ for $5.5 \mathrm{~h}$ (Karam 1993), In addition, we measured carbon (C), nitrogen (N), using a Carlo Erba NA 1500 CHN Analyzer (Carlo Erba, Milan, Italy), and phosphorus (P) concentrations using the ash/acid extraction method followed by spectrophometric analysis using the ascorbic acid method and calculated molar ratios on initial $(n=5$ of each material) and final root $(n=112)$ and litter breakdown material $(n=112)$ and within surface accretion $(n=80)$.

\section{Data Analyses}

We used models to quantify how patch-scale differences in specific stocks and fluxes of OC were driven by patch-scale $(3 \cdot 3 \mathrm{~m})$ vegetation type (marsh or mangrove), plot-scale $(24 \cdot 42 \mathrm{~m})$ mangrove cover $(0-100 \%)$, and location within plots (fringe or interior). For each response variable, we used analysis of covariance (ANCOVA) to create maximal models of the equation: Response $=\operatorname{Patch}(a) \cdot \operatorname{Plot}(b) \cdot \operatorname{Location}(c)$, where Patch is patch vegetation type ("marsh" or "mangrove"), Plot is the plot-scale mangrove cover. Location is the zone within the coast to interior gradient ("fringe" or "interior"). We then used stepwise model simplification to identify the minimal adequate model based on Akaike's Information Criterion with a correction for finite sample size 
(AICc) (Hurvich and Tsai 1989). Equations are reported as Helmert contrasts, which identify a mean intercept for all data.

We calculated plot-scale weighted averages for each variable. We calculated plot weighted averages as Plot weighted average $=($ Plot mangrove average $\bullet$ plot mangrove cover $)+($ Plot marsh average $\bullet$ plot marsh cover $)$. We regressed weighted averages against plot mangrove cover, selecting either linear or quadratic models as best fit based on adjusted $\mathrm{R}^{2}$ and $P$-values. All statistical analyses were performed using $\mathrm{R}$ (version 3.3.2, R Core Team 2016).

\section{RESULTS}

\section{Organic Carbon Standing Stocks}

Aboveground biomass was best explained by a model including patch treatment times plot location and their interaction (Table 1). Organic carbon stock in aboveground plant biomass in mangrove patches was $1630 \%$ higher than in marsh patches, and biomass was $41 \%$ higher in fringe than interior patches (Figure 1a; Table 1). Mangrove biomass was 50\% higher in the plot fringe than the interior (Figure 1a; Table 1). Plotweighted average OC showed a positive linear increase in aboveground biomass with plot mangrove cover (Table 2; Figure 1b).

Total belowground biomass was best described by patch vegetation type and location. On average, mangrove patches contained $61 \%$ more total belowground biomass $(0-30 \mathrm{~cm})$ than marsh patches and interior plots had $256 \%$ more than coastal plots (Table 1; Figure 1c). Shallow root biomass $(0-15 \mathrm{~cm})$ was driven by location, and was $678 \%$ greater in the interior than the fringe (Table 1). Deeper root biomass $(15-30 \mathrm{~cm})$ was 
driven by patch vegetation and location (Table 1). Deeper root OC $(15-30 \mathrm{~cm})$ was higher in mangrove vegetation and was higher in the interior than the fringe (Table 1). Total belowground biomass $(0-30 \mathrm{~cm})$ had a positive linear relationship with plot-scale mangrove cover (Table 2; Figure 1d).

Soil OC content was best predicted by patch vegetation type and location. Soil percent $\mathrm{OC}$ in mangrove patches was $2.6 \pm 0.8 \%$ higher, and fringe marshes had $1.8 \pm$ $0.8 \%$ higher soil OC (Table 1; Figure 1e). Plot weighted average soil OC was not related to plot mangrove cover (Table 2; Figure 1f).

\section{Organic Matter Inputs}

Root productivity $(0-30 \mathrm{~cm})$ was not related to patch, or plot-scale mangrove treatment, but was $180 \%$ higher in interior than fringe patches (Table 1). There was no relationship between plot weighted average and plot mangrove cover.

After 11 months, surface OC accretion was best described with a negative quadratic relationship to plot mangrove cover (Table 1; Figure 2a). Plot-weighted average accretion was similarly controlled by a quadratic relationship to plot mangrove cover (Table 2; Figure 3b).

After 22 months, surface OC accretion was best described by patch and location. Mangrove patches had 70\% more surface OC accretion than marsh patches and accretion was $126 \%$ higher in the wetland fringe than the interior (Table 1). After 22 months, there were no longer relationships between plot mangrove cover and surface accretion or between plot-weighted average OC accretion and plot mangrove cover (Table 2; Figure 2d). 
The chemical quality of sediment and organic matter that accreted on the soil surface differed by patch, plot and location after 22 months (Table 3). Percent C was $210 \%$ higher in mangrove than marsh patches $(P=0.04), 17 \%$ higher in fringe than interior plots $(P=0.05)$ and was positively related to plot mangrove cover $(P=0.05$; Table 1; Table 3). Percent $\mathrm{N}$ was $68 \%$ higher in mangrove than marsh patches $(P=0.03)$, $9 \%$ higher in fringe than interior patches $(P=0.008)$ and was positively related to plot mangrove cover $(P=0.003$; Table 1; Table 3). C:N molar ratio was $138 \%$ higher in mangrove than marsh patches $(P=0.03$; Table 1 ; Table 3$)$. Plot- weighted average $\mathrm{C}$ to $\mathrm{N}$ ratios increased at the plot level with increasing mangrove cover (Table 2).

\section{Microclimate}

Interception of PAR by vegetation increased from $25.2 \pm 5.7 \%$ in marsh to $97 \pm$ $5.7 \%$ in mangrove patches, whereas plot mangrove cover had a slight negative impact on PAR interception (Table 1; Figure 3a). Plot weighted average PAR interception increased linearly with mangrove cover (Table 2; Figure 3b).

Average soil temperature was $1.4^{\circ} \mathrm{C}$ cooler in mangrove than marsh patches and temperature had a quadratic relationship to plot mangrove cover (Table 1; Figure 3c). Plot weighted average soil temperature had a quadratic relationship with plot-scale mangrove cover, increasing from $0-22 \%$ plot-scale mangrove cover before decreasing with higher mangrove cover (Table 2; Figure 3d).

\section{Organic Matter Breakdown}

Wood $k$ on the soil surface was negatively related to plot mangrove cover (Table 1; Figure 4a) and plot-weighted wood $k$ was negatively related to plot mangrove cover 
(Table 2; Figure 4b). Cellulose $k$ was $38 \%$ higher in marsh than mangrove patches, $130 \%$ higher in interior than fringe patches and was negatively related to plot mangrove cover (Table 1; Figure 4c). Plot-weighted average cellulose $k$ was positively and non-linearly related to plot mangrove cover (Table 2; Figure 4d).

Surface litter $k$ was primarily driven by leaf litter type, as marsh (B. maritima) litter $k$ was $1000 \%$ higher than mangrove (A. germinans) $k(P<0.001)$. Marsh litter $k$ was not impacted by plot- or patch-scale vegetation or location, while mangrove litter $k$ was higher in mangrove patches, and broke down faster in marsh interior than the fringe (Table 1; Figure 4e). Plot-weighted average mangrove litter $k$ had a positive quadratic relationship to plot-scale mangrove cover (Figure 4f).

In shallow soil $(0-15 \mathrm{~cm})$, wood $k$ was best described by patch vegetation and location within the plot (Table 1; Figure 5a). Wood substrates broke down $41 \%$ faster in mangrove than marsh patches, and 10\% faster in coastal than interior patches (Table 1; Figure 5a). Plot-weighted average wood $k$ was positively and linearly related to plot mangrove cover (Figure $5 b$ ). Marsh derived root $k$ was $15 \%$ higher than mangrove roots, and root $k$ was $10 \%$ higher in fringe than mangrove patches (Table 1; Figure 5c). Plotweighted average $k$ was not related to plot mangrove cover (Figure 5e).

In deeper soil $(15-30 \mathrm{~cm})$, wood $k$ was not related to patch vegetation, but was higher in fringe than interior patches (Table 1; Figure 6a). Plot weighted average $k$ was not related to plot mangrove cover (Table 1; Figure 6b). Marsh root $k$ in deeper soil (15$30 \mathrm{~cm}$ ) was $54 \%$ higher than mangrove root $k$ (Table 1; Figure 6c). Plot-weighted average root $k$ was negatively related to plot mangrove cover (Table 2; Figure 6d). 


\section{Organic Matter Stoichiometry}

Marsh (B. maritima) litter and roots contained higher percentages of $\mathrm{N}$ and $\mathrm{P}$ than mangrove (A. germinans) which had higher percent $\mathrm{C}$ (Table 2), leading to higher $\mathrm{C}$ to $\mathrm{N}$ ratios of initial mangrove litter (290\%) and roots $(70 \%)$ than marsh litter $(P<0.001)$. Mangrove $\mathrm{C}$ to $\mathrm{P}$ ratios were higher in mangrove litter $(130 \%)$ and roots $(270 \%)$ than marsh $(P<0.001)$. $\mathrm{N}$ to $\mathrm{P}$ ratios were $70 \%$ higher in marsh than mangrove litter, but conversely were $130 \%$ higher in mangrove than marsh roots $(P<0.001$; Table 2$)$.

\section{DISCUSSION}

Coastal wetlands store more OC in their soil per area than other ecosystems (Chmura et al. 2003; McLeod et al. 2011), providing a "blue carbon" sink and maintaining wetland elevation in equilibrium with sea-level rise (Nyman et al. 2006; McKee et al. 2007; Morris et al. 2016; Kirwan et al. 2016). A crucial unknown variable is how shifting foundation species may alter OC storage following mangrove encroachment and expansion or die-back. Studies comparing adjacent vegetation types are divided on whether mangrove ecosystems facilitate greater (Bianchi et al. 2013; Comeaux et al. 2013; Yando et al. 2016) or similar (Perry and Mendelssohn 2009; Henry and Twilley 2013; Doughty et al. 2015; McKee et al. 2017) OC stocks and storage rates than marshes. Furthermore, studying adjacent vegetation types risks confounding the impacts of the vegetation itself with the abiotic conditions driving vegetation zonation. Here, we addressed this problem directly by creating a vegetation manipulation experiment in the field that isolated the impacts of vegetation from underlying abiotic conditions at multiple spatial scales. 


\section{Organic Matter Standing Stocks}

Mangrove aboveground biomass was $1630 \%$ higher than marsh (Table 1), likely leading to major structural and functional differences that drove a strong linear increase in aboveground $\mathrm{C}$ storage (Plot 1a, 1b). Our research sites, and much of the western Gulf of Mexico, experiences low rainfall, and a microtidal environment that creates high salinity conditions and is therefore dominated by stress-tolerant succulent plant species (e.g., B. maritima) with only one tenth the aboveground biomass of more productive marshes in the Gulf of Mexico (Yando et al. 2016). Similarly, mangrove aboveground biomass tends to decrease towards the latitudinal limits of species ranges (Osland et al. 2015). Mangrove trees can develop greater aboveground biomass than marshes, but the indirect impacts of aboveground biomass may also be profound (Kelleway et al. 2017).

Mangrove patches had 60\% higher belowground biomass than marshes that increased linearly at the plot level (Figure 1c, 1d), potentially increasing OC storage and sediment elevation (Krauss et al. 2013). The values we obtained from both marsh and mangrove patches were on the low end for coastal wetlands (Castañeda-Moya et al. 2011; Cormier et al. 2015), reflecting stressful conditions. The differences in root biomass between marsh and mangrove patches in our study were driven by higher root biomass at lower depths $(15-30 \mathrm{~cm})$ for mangroves (Table 1). Mangroves increased root biomass in the deeper soil, where roots break down slowly (Table 1). thereby potentially enhancing OC storage and vertical accretion.

In our study mangroves had a scale-dependent impact on soil OC storage, as mangroves increased soil OC at the patch-scale, but did not increase plot-scale mangrove 
cover. Soil OC storage integrates organic matter inputs and losses through time, and mangrove encroachment has increased OC in Texas (Bianchi et al. 2013; Comeaux et al. 2013; Yando et al. 2016) and Australia (Kelleway et al. 2017), but had no impact elsewhere in the Southeast United States (Perry and Mendelssohn 2009; Henry 2012; Henry and Twilley 2013; Doughty et al. 2015). In our study, mangrove cover lead to both positive (increased biomass, lower breakdown of autochthonous litter and roots, lower surface breakdown) and negative (reduced allochthonous inputs and priming of surface soil) impacts on net OC storage, which may have largely offset each other. Alternatively, the short duration of the mangrove treatments prior to soil OC measurements (20 months) may have limited development of differences in soil OC develop. Guo et al. (2017), working in the same coastal plots, found that soil OC significantly decreased over time in plots where mangroves had been removed, suggesting that we may observe differences in soil OC stocks with more time.

\section{Organic Matter Fluxes}

The contribution of roots to soil OC is driven by productivity, but also by root turnover and breakdown rates. Living and dead root accumulation often drives $\mathrm{C}$ storage and elevation change in coastal wetlands (McKee 2011), due to slow breakdown in inundated soils (Middleton and McKee 2001). Because mangrove roots accumulated more living biomass and produced more recalcitrant root litter, mangrove vegetation is likely to lead to increased soil $\mathrm{C}$ storage through time, despite similar productivity rates.

Mangrove cover lead to decreased short-term (11 months) allochthonous inputs due to blocking of coastal organic matter subsidies, but the buildup of recalcitrant 
autochthonous organic matter lead to increased OC accretion in mangrove patches after 22 months (Figure 2). We predicted that mangrove vegetation would enhance surface accretion, because of increased trapping of allochthonous materials with greater aboveground biomass (Morris et al. 2002; Fagherazi et al. 2012; Morris et al. 2016) and because woody mangrove stems, roots and pneumatophores may create greater resistance to water flow and enhance trapping (Young and Harvey 1996; Comeaux et al. 2013). However, in our experimental site, marine-derived wrack was restricted to the coastal edge of plots with high mangrove cover (Guo et al. 2017), indicating that the plant characteristics that trap allochthonous material within wetlands in some environmental settings, may also create a biological barrier to coastal subsidies.

Our study shows that mangroves may reduce the rate of soil OC inputs, but that long-lasting mangrove organic matter drove higher accretion rates after 22 months (Figure 2). Mangroves may contribute $\mathrm{OC}$ to the soil surface at a slower rate than some marshes because they allocate more aboveground biomass to long-term storage structures than marsh vegetation, which deposit most of their aboveground biomass to the soil surface annually (Kelleway et al. 2017). Labile coastal subsidies and marsh litter may drive ephemeral increases in accretion, but are unlikely to increase long-term OC storage. Mangrove litter and root C:N were much higher than that from marshes, and accreting material on the soil surface was positively related to mangrove cover (Table 1). Surface deposition is often important to marsh elevation (Morris et al. 2002; Lovelock et al. 2015), and mangroves may restrict allochthonous material from interior marshes, but only recalcitrant or buried OC additions lead to sustained accretion (Morris et al. 2016). 
Climate and organic matter quality drive differences in organic matter breakdown (Cornwell et al. 2008) and mangroves decreased breakdown rates by reducing temperature and producing lower quality litter and roots. Mangrove leaves broke down ten times more slowly than marshes leaves due to higher initial $\mathrm{C}$ to $\mathrm{N}$ and $\mathrm{C}$ to $\mathrm{P}$ ratios (Table 3). Furthermore,we focused on leaves and roots (the largest inputs of autochthonous OC to the soil) but mangroves may further enhance soil OC storage by the production of recalcitrant wood that can take decades to decompose (Krauss et al. 2005; Middleton and McKee 2001). Mangrove vegetation intercepted PAR and decreased average soil temperature $1.4^{\circ} \mathrm{C}$ (Figure 3), reducing OC loss from wood and cellulose standard substrates on the soil surface. Both PAR and temperature have been shown to increase OC breakdown (Fierer et al. 2005; Brandt et al. 2010). Temperature increases are predicted to drive globally important losses of soil C in terrestrial and wetland ecosystems in the coming decades (Crowther et al. 2016; Kirwan and Blum 2011). By altering microclimate and organic matter quality, mangrove encroachment into herbaceous marshes may enhance wetland OC storage through biophysical feedbacks.

Mangrove roots broke down more slowly in the soil than marsh roots, but mangroves also enhanced $k$ of standard substrates within the surface soil. Mangroves (including A. germinans) have been shown to aerate soil, thus likely increasing breakdown in anaerobic soils (Gill and Tomlinson 1977; Scholander et al. 1955). Roots may enhance decomposition of previously stored OC through priming (Kusyakov et al. 2010), potentially driving OC loss despite increased root inputs (Bernal et al. 2016). In the short term, mangrove roots may prime OC breakdown, but once established, 
recalcitrant dead roots in the soil often comprise the majority of mangrove peats, which can persist for thousands of years (McKee et al. 2007).

\section{Implications for Future Coastal Wetland Sustainability}

Coastal wetland vegetation has facilitated OC storage and created much of the substrate for wetlands to adjust their elevation to SLR throughout the Holocene (McKee et al. 2007; Willard and Bernhardt 2011), but increasing rates of SLR make wetlands more vulnerable to loss from submergence. Our results indicate the potential for increased OC storage as mangroves encroach into temperate wetlands (Saintillan et al. 2014; Osland et al. 2016) through increasing OC longevity, but also pinpoint trade-offs among specific fluxes, potentially explaining how responses to mangrove encroachment differs locally, regionally and globally.

In our study, we found increases in some mechanisms of OC storage, but we also found trade-offs in stocks and fluxes that may lead to different outcomes in wetlands in other environmental settings. Additionally, we found higher soil OC in mangrove patches than marsh patches, but small scale differences did not translate to higher OC at the plot level. Although mangroves have the capacity to store more OC in aboveground biomass than marshes (Kelleway et al. 2017), OC belowground has a much longer residence time (Souza Filho et al. 2004) and therefore a greater impact on atmospheric carbon sequestration. Global reviews comparing marshes and mangrove soil $\mathrm{C}$ have identified higher OC stocks in mangrove soils (Duarte et al. 2013), but similar rates of sequestration (Chmura et al. 2003). Over the short term, trade-offs in specific OC fluxes may minimize differences in soil OC storage in marsh and mangrove ecosystems (Doughty et al. 2016; 
Henry and Twilley 2013; Perry and Mendelssohn 2009; Yando et al. 2016). However, soil OC accumulation is a slow process and the impacts of mangrove encroachment on soil development can take decades in natural (Kelleway et al. 2017) and restored ecosystems (Osland et al. 2012). Additionally, coastal wetlands vary drastically in the sources of accreting OC (Ewel et al. 1998; McKee 2011), and therefore the importance of allochthonous and autochthonous sources may have drastically different implications depending on setting. Therefore, predicting changes in soil OC storage due to vegetation shifts may require extensive knowledge of the local ecosystem.

In terrestrial and wetland ecosystems, woody encroachment often increases OC storage (Elridge et al. 2011), but only under certain climatic conditions (Knapp et al. 2008; Yando et al. 2016) and functional outcomes depend on traits of the species involved (Kominoski et al. 2013). Particularly, woody encroachment tends to increase OC storage in arid environments, but not necessarily in humid environments (Knapp et al. 2013; Yando et al. 2016). Similarly, the impact of mangrove encroachment on OC storage will likely differ based on preexisting edaphic conditions and sources of accretion (McKee 2011).

Climate change is driving latitudinal mangrove expansion in many locations globally (Saintillan et al. 2014), including the northern Gulf of Mexico (Osland et al. 2013; Armitage et al. 2015), but we lack a quantitative understanding of likely functional changes. Furthermore, mangrove expansion is limited by dispersal and environmental conditions (Osland et al. 2017), such as fire (Smith et al. 2013), precipitation (Osland et al. 2016), relative sea level (Rogers et al. 2006), and biological feedbacks on microclimate (Guo et al. 2013), water quality (Jiang et al. 2014), and propagule 
recruitment (McKee et al. 2007), thus incomplete mangrove encroachment will likely be a widespread phenomenon. As climate change interacts with vegetation transitions, mangroves and marshes are likely to create a heterogeneous landscape making the transitional stages of mangrove colonization an important and ever-present vegetation community type along the ecotone (Risser 1990). However, ultimately climate is likely to drive mangrove encroachment locally and across the subtropics (Osland et al. 2013; Saintillan et al. 2014). In our study, mangroves increased potential OC storage by increasing biomass, producing recalcitrant OM and reducing surface soil temperature, however, mangroves also reduced allochthonous coastal organic matter subsidies and enhanced surface soil breakdown. Because mangroves impacted OC stocks and fluxes in both positive and negative directions, our study shows that the impact of mangrove encroachment is likely to vary among locations.

\section{ACKNOWLEDGEMENTS}

This research was supported in part by an Institutional Grant (NA10OAR4170099) to the Texas Sea Grant College Program from the National Sea Grant Office, National Oceanic and Atmospheric Administration, U.S. Department of Commerce. We also thank Florida International University Department of Biological Sciences for financial support. Ashley Whitt, Sayantani Dastidar, Kristina Morales, Daniel Rivera, Claudia Garcia, Hilda Deleon, Alexis Ramos, Marco Fernandez provided field and lab assistance. All views, opinions, findings, conclusions and recommendations expressed in this material are those of the author(s) and do not necessarily reflect the 
opinions of the Texas Sea Grant College Program or the National Oceanic and Atmospheric Administration.

\section{LITERATURE CITED}

Barbier, E. B., S. D. Hacker, C. Kennedy, E. W. Koch, A. C. Stier, and B. R. Silliman. 2011. The value of estuarine and coastal ecosystem services. Ecological Monographs 81:169-193.

Bernal, B., D. C. McKinley, B. A. Hungate, P. M. White, T. J. Mozdzer, and J. P. Megonigal. 2016. Limits to soil carbon stability; Deep, ancient soil carbon decomposition stimulated by new labile organic inputs. Soil Biology \& Biochemistry 98:85-94.

Castaneda-Moya, E., R. R. Twilley, V. H. Rivera-Monroy, B. D. Marx, C. CoronadoMolina, and S. M. L. Ewe. 2011. Patterns of Root Dynamics in Mangrove Forests Along Environmental Gradients in the Florida Coastal Everglades, USA. Ecosystems 14:1178-1195.

Chen, I. C., J. K. Hill, R. Ohlemuller, D. B. Roy, and C. D. Thomas. 2011. Rapid Range Shifts of Species Associated with High Levels of Climate Warming.

Science 333: 1024-1026.

Chmura, G. L., S. C. Anisfeld, D. R. Cahoon, and J. C. Lynch. 2003. Global carbon sequestration in tidal, saline wetland soils. Global Biogeochemical Cycles 17:12.

Comeaux, R. S., M. A. Allison, and T. S. Bianchi. 2012. Mangrove expansion in the Gulf of Mexico with climate change: Implications for wetland health and resistance to rising sea levels. Estuarine Coastal and Shelf Science 96:81-95.

Cormier, N., R. R. Twilley, K. C. Ewel, and K. W. Krauss. 2015. Fine root productivity varies along nitrogen and phosphorus gradients in high-rainfall mangrove forests of Micronesia. Hydrobiologia 750:69-87.

Cornwell, W. K., J. H. C. Cornelissen, K. Amatangelo, E. Dorrepaal, V. T. Eviner, O. Godoy, S. E. Hobbie, B. Hoorens, H. Kurokawa, N. Perez-Harguindeguy, H. M. Quested, L. S. Santiago, D. A. Wardle, I. J. Wright, R. Aerts, S. D. Allison, P. van Bodegom, V. Brovkin, A. Chatain, T. V. Callaghan, S. Diaz, E. Garnier, D. E. Gurvich, E. Kazakou, J. A. Klein, J. Read, P. B. Reich, N. A. Soudzilovskaia, M. V. Vaieretti, and M. Westoby. 2008. Plant species traits are the predominant control on litter decomposition rates within biomes worldwide. Ecology Letters 11:1065-1071. 
Costanza, R., R. de Groot, P. Sutton, S. van der Ploeg, S. J. Anderson, I. Kubiszewski, S. Farber, and R. K. Turner. 2014. Changes in the global value of ecosystem services. Global Environmental Change-Human and Policy Dimensions 26:152158.

Craft, C. B., and C. J. Richardson. 1993. Peat accretion and N, P, and organic C accumulation in nutrient-enriched and unenriched Everglades peatlands. Ecological Applications 3:446-458.

Crowther, T. W., K. E. O. Todd-Brown, C. W. Rowe, W. R. Wieder, J. C. Carey, M. B. Machmuller, B. L. Snoek, S. Fang, G. Zhou, S. D. Allison, J. M. Blair, S. D. Bridgham, A. J. Burton, Y. Carrillo, P. B. Reich, J. S. Clark, A. T. Classen, F. A. Dijkstra, B. Elberling, B. A. Emmett, M. Estiarte, S. D. Frey, J. Guo, J. Harte, L. Jiang, B. R. Johnson, G. Kroel-Dulay, K. S. Larsen, H. Laudon, J. M. Lavallee, Y. Luo, M. Lupascu, L. N. Ma, S. Marhan, A. Michelsen, J. Mohan, S. Niu, E. Pendall, J. Penuelas, L. Pfeifer-Meister, C. Poll, S. Reinsch, L. L. Reynolds, I. K. Schmidt, S. Sistla, N. W. Sokol, P. H. Templer, K. K. Treseder, J. M. Welker, and M. A. Bradford. 2016. Quantifying global soil carbon losses in response to warming. Nature 540:104-+.

D'Odorico, P., Y. F. He, S. Collins, S. F. J. De Wekker, V. Engel, and J. D. Fuentes. 2013. Vegetation-microclimate feedbacks in woodland-grassland ecotones. Global Ecology and Biogeography 22:364-379.

Dangendorf, S., M. Marcos, G. Woppelmannc, C. P. Conrad, T. Frederikse, and R. Riva. 2017. Reassessment of 20th century global mean sea level rise. Proceedings of the National Academy of Sciences of the United States of America 114:59465951.

Doughty, C. L., J. A. Langley, W. S. Walker, I. C. Feller, R. Schaub, and S. K. Chapman. 2016. Mangrove Range Expansion Rapidly Increases Coastal Wetland Carbon Storage. Estuaries and Coasts 39:385-396.

Duarte, C. M., I. J. Losada, I. E. Hendriks, I. Mazarrasa, and N. Marba. 2013. The role of coastal plant communities for climate change mitigation and adaptation. Nature Climate Change 3:961-968.

Eldridge, D. J., M. A. Bowker, F. T. Maestre, E. Roger, J. F. Reynolds, and W. G. Whitford. 2011. Impacts of shrub encroachment on ecosystem structure and functioning: towards a global synthesis. Ecology Letters 14:709-722.

Ewel, K. C., R. R. Twilley, and J. E. Ong. 1998. Different kinds of mangrove forests provide different goods and services. Global Ecology and Biogeography Letters 7:83-94. 
Fagherazzi, S., L. Carniello, L. D'Alpaos, and A. Defina. 2006. Critical bifurcation of shallow microtidal landforms in tidal flats and salt marshes. Proceedings of the National Academy of Sciences of the United States of America 103:8337-8341.

Fierer, N., J. M. Craine, K. McLauchlan, and J. P. Schimel. 2005. Litter quality and the temperature sensitivity of decomposition. Ecology 86:320-326.

Filho, P., M. C. L. Cohen, R. J. Lara, G. C. Lessa, B. Koch, and H. Behling. 2006. Holocene coastal evolution and facies model of the Braganca macrotidal flat on the Amazon Mangrove Coast, Northern Brazil. Journal of Coastal Research:306310 .

Gill A. M.and P. B. Tomlinson. 1977. Studies on the growth of red mangrove (Rhizophora mangle L.). The adult root system. Biotropica 9:145-155.

Guo, H., C. Weaver, S. P. Charles, A. Whitt, S. Dastidar, P. D'Odorico, J. D. Fuentes, J. S. Kominoski, A. R. Armitage, and S. C. Pennings. 2017. Coastal regime shifts: rapid responses of coastal wetlands to changes in mangrove cover. Ecology 98:762-772.

Henry, K. M., and R. R. Twilley. 2013. Soil Development in a Coastal Louisiana Wetland during a Climate-Induced Vegetation Shift from Salt Marsh to Mangrove. Journal of Coastal Research 29:1273-1283.

Hurvich, C. M., and C. L. Tsai. 1989. Regression and time-series model selection in small samples. Biometrika 76:297-307.

Karam A. 1993. Chemical properties of organic soils. In: Carter MR, for Canadian Society of Soil Science, Eds. Soil sampling and methods of analysis. London: Lewis Publishers. Pp 459- 71 .

Kelleway, J. J., K. Cavanaugh, K. Rogers, I. C. Feller, E. Ens, C. Doughty, and N. Saintilan. 2017. Review of the ecosystem service implications of mangrove encroachment into salt marshes. Global Change Biology 23:3967-3983.

Kelleway, J. J., N. Saintilan, P. I. Macreadie, C. G. Skilbeck, A. Zawadzki, and P. J. Ralph. 2016. Seventy years of continuous encroachment substantially increases "blue carbon' capacity as mangroves replace intertidal salt marshes. Global Change Biology 22:1097-1109.

Kirwan, M. L., and L. K. Blum. 2011. Enhanced decomposition offsets enhanced productivity and soil carbon accumulation in coastal wetlands responding to climate change. Biogeosciences 8:987-993. 
Kirwan, M. L., and J. P. Megonigal. 2013. Tidal wetland stability in the face of human impacts and sea-level rise. Nature 504:53-60.

Kirwan, M. L., S. Temmerman, E. E. Skeehan, G. R. Guntenspergen, and S. Fagherazzi. 2016. Overestimation of marsh vulnerability to sea level rise. Nature Climate Change 6:253-260.

Knapp, A. K., J. M. Briggs, S. L. Collins, S. R. Archer, M. S. Bret-Harte, B. E. Ewers, D. P. Peters, D. R. Young, G. R. Shaver, E. Pendall, and M. B. Cleary. 2008. Shrub encroachment in North American grasslands: shifts in growth form dominance rapidly alters control of ecosystem carbon inputs. Global Change Biology 14:615-623.

Kominoski, J. S., J. J. F. Shah, C. Canhoto, D. G. Fischer, D. P. Giling, E. Gonzalez, N. A. Griffiths, A. Larranaga, C. J. LeRoy, M. M. Mineau, Y. R. McElarney, S. M. Shirley, C. M. Swan, and S. D. Tiegs. 2013. Forecasting functional implications of global changes in riparian plant communities. Frontiers in Ecology and the Environment 11:423-432.

Krauss, K. W., T. W. Doyle, R. R. Twilley, T. J. Smith, K. R. T. Whelan, and J. K. Sullivan. 2005. Woody debris in the mangrove forests of South Florida. Biotropica 37:9-15.

Krauss, K. W., K. L. McKee, C. E. Lovelock, D. R. Cahoon, N. Saintilan, R. Reef, and L. Z. Chen. 2014. How mangrove forests adjust to rising sea level. New Phytologist 202:19-34.

Kuzyakov, Y. 2010. Priming effects: Interactions between living and dead organic matter. Soil Biology \& Biochemistry 42:1363-1371.

Li, P. X., N. Wang, W. M. He, B. O. Krusi, S. Q. Gao, S. M. Zhang, F. H. Yu, and M. Dong. 2008. Fertile islands under Artemisia ordosica in inland dunes of northern China: Effects of habitats and plant developmental stages. Journal of Arid Environments 72:953-963.

Lovelock, C. E., D. R. Cahoon, D. A. Friess, G. R. Guntenspergen, K. W. Krauss, R. Reef, K. Rogers, M. L. Saunders, F. Sidik, A. Swales, N. Saintilan, L. X. Thuyen, and T. Triet. 2015. The vulnerability of Indo-Pacific mangrove forests to sea-level rise. Nature 526:559-U217.

McKee, K. L. 2011. Biophysical controls on accretion and elevation change in Caribbean mangrove ecosystems. Estuarine Coastal and Shelf Science 91:475483. 
McKee, K. L., D. R. Cahoon, and I. C. Feller. 2007. Caribbean mangroves adjust to rising sea level through biotic controls on change in soil elevation. Global Ecology and Biogeography 16:545-556.

McLeod, E., G. L. Chmura, S. Bouillon, R. Salm, M. Bjork, C. M. Duarte, C. E. Lovelock, W. H. Schlesinger, and B. R. Silliman. 2011. A blueprint for blue carbon: toward an improved understanding of the role of vegetated coastal habitats in sequestering CO2. Frontiers in Ecology and the Environment 9:552560 .

Middleton, B. A., and K. L. McKee. 2001. Degradation of mangrove tissues and implications for peat formation in Belizean island forests. Journal of Ecology 89:818-828.

Morris, J. T., P. V. Sundareshwar, C. T. Nietch, B. Kjerfve, and D. R. Cahoon. 2002. Responses of coastal wetlands to rising sea level. Ecology 83:2869-2877.

Nyman, J. A., R. J. Walters, R. D. Delaune, and W. H. Patrick. 2006. Marsh vertical accretion via vegetative growth. Estuarine Coastal and Shelf Science 69:370-380.

Osland, M. J., N. Enwright, R. H. Day, and T. W. Doyle. 2013. Winter climate change and coastal wetland foundation species: salt marshes vs. mangrove forests in the southeastern United States. Global Change Biology 19:1482-1494.

Osland, M. J., N. M. Enwright, R. H. Day, C. A. Gabler, C. L. Stagg, and J. B. Grace. 2016. Beyond just sea-level rise: considering macroclimatic drivers within coastal wetland vulnerability assessments to climate change. Global Change Biology 22:1-11.

Osland, M. J., L. C. Feher, K. T. Griffith, K. C. Cavanaugh, N. M. Enwright, R. H. Day, C. L. Stagg, K. W. Krauss, R. J. Howard, J. B. Grace, and K. Rogers. 2017. Climatic controls on the global distribution, abundance, and species richness of mangrove forests. Ecological Monographs 87:341-359.

Osland, M. J., A. C. Spivak, J. A. Nestlerode, J. M. Lessmann, A. E. Almario, P. T. Heitmuller, M. J. Russell, K. W. Krauss, F. Alvarez, D. D. Dantin, J. E. Harvey, A. S. From, N. Cormier, and C. L. Stagg. 2012. Ecosystem Development After Mangrove Wetland Creation: Plant-Soil Change Across a 20-Year Chronosequence. Ecosystems 15:848-866.

Perry, C. L., and I. A. Mendelssohn. 2009. Ecosystem effects of expanding population of Avicennia germinans in a Louisiana salt marsh. Wetlands 29:396-406.

Risser, P. G. 1990. The ecological importance of land-water ecotones. Ecology and Management of Aquatic-Terrestrial Ecotones 4:7-21. 
Rogers, K., K. M. Wilton, and N. Saintilan. 2006. Vegetation change and surface elevation dynamics in estuarine wetlands of southeast Australia. Estuarine Coastal and Shelf Science 66:559-569.

Saintilan, N., N. C. Wilson, K. Rogers, A. Rajkaran, and K. W. Krauss. 2014. Mangrove expansion and salt marsh decline at mangrove poleward limits. Global Change Biology 20:147-157.

Scholander P. F., L. Van Dam and S. I. Scholander. 1955. Gas exchange in the roots of mangroves. American Journal of Botany 42:92-98.

Smith, T. J., A. M. Foster, G. Tiling-Range, and J. W. Jones. 2013. Dynamics of mangrove-marsh ecotones in subtropical coastal wetlands: Fire, Sea-level rise, and water levels. Fire Ecology 9:66-77.

Thieler E. R. and E. S. Hammar-Klose. 2000. National Assessment of Coastal Vulnerability to Future Sea-Level Rise: Preliminary Results for the U.S. Gulf of Mexico Coast. U.S. Geological Survey, Open-File Report 00-179.

Twilley, R. R., A. E. Lugo, and C. Pattersonzucca. 1986. Litter production and turnover in basin mangrove forests of Southwest Florida. Ecology 67:670-683.

Van Auken, O. W. 2000. Shrub invasions of North American semiarid grasslands. Annual Review of Ecology and Systematics 31:197-215.

Vogt, K. A., D. J. Vogt, and J. Bloomfield. 1998. Analysis of some direct and indirect methods for estimating root biomass and production of forests at an ecosystem level. Plant and Soil 200:71-89.

Willard, D. A., and C. E. Bernhardt. 2011. Impacts of past climate and sea level change on Everglades wetlands: placing a century of anthropogenic change into a lateHolocene context. Climatic Change 107:59-80.

Yando, E. S., M. J. Osland, J. M. Willis, R. H. Day, K. W. Krauss, and M. W. Hester. 2016. Salt marsh-mangrove ecotones: using structural gradients to investigate the effects of woody plant encroachment on plant-soil interactions and ecosystem carbon pools. Journal of Ecology 104:1020-1031.

Young B. M., L. E. Harvey. 1996. A spatial analysis of the relationship Between mangrove (Avicenia marina var. australasica) physiognomy and sediment accretion in the Hauraki Plains, New Zealand. Estuarine, Coastal and Shelf Science 42:231-246. 
Table 1. Drivers of patch level stocks and fluxes of output from linear models. We list average and standard deviation of stocks, and fluxes of organic carbon (OC) in $3 \cdot 3 \mathrm{~m}$ patches based on vegetation type (mangrove and marsh) and location(interior and fringe). Additionally, we identify minimum adequate models with AICc, from the model: Response= $\operatorname{Patch}(p) \bullet \operatorname{Plot}(P) \bullet \operatorname{Plot}(P)^{2} \bullet \operatorname{Location}(l)$, where Patch is patch vegetation type ("marsh" or "mangrove"), Plot is the percent mangrove cover at the $(24 \cdot 42 \mathrm{~m})$ plot scale. We list $P$ and adjusted $\mathrm{R}^{2}$ values for each model.

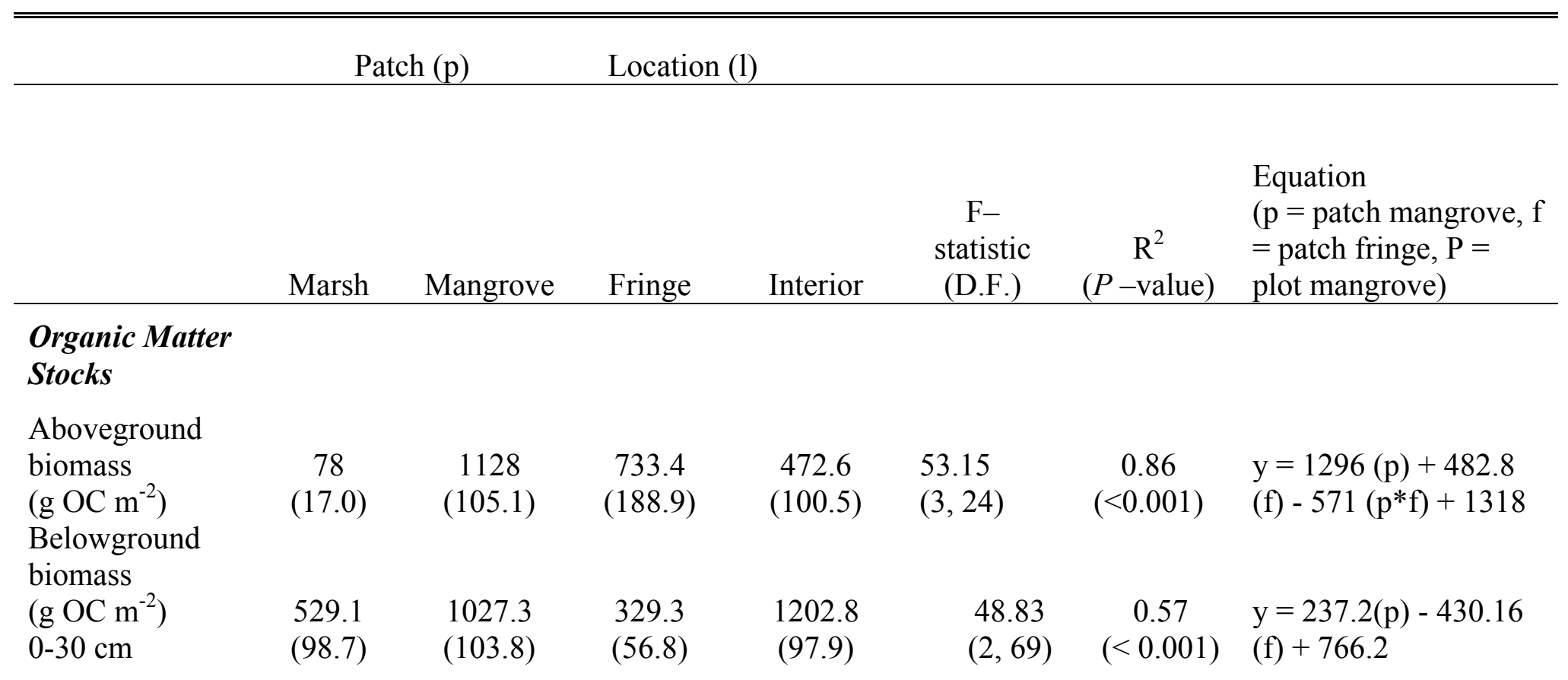


Belowground

biomass

$\left(\mathrm{g} \mathrm{OC} \mathrm{m}^{-2}\right)$

$0-15 \mathrm{~cm}$

377.5

(84.4)

556.8

(77.7)

104.4

(22.6)

810.3

(75.5)

41.96

$(2,69)$

0.52

$\mathrm{y}=79.9(\mathrm{p})-350.7(\mathrm{f})+$

Belowground

biomass

$\left(\mathrm{g} \mathrm{OC} \mathrm{m}^{-2}\right)$

$15-30 \mathrm{~cm}$

153.

(27.9)

470.5

226.5

(39.5) (40.2)

392.5

$31.15 \quad 0.46 \quad \mathrm{y}=474.4(\mathrm{p})-705.9(\mathrm{f})$

4.3

Surface Soil

$\%$ OC

$4.1 \quad 5.3$

(0.2)

(0.4)

5.1

$(0.4)$

(0.3)

6.15

$(2,77)$

0.12

$(0.003)$

$y=126(p)-78.7(f)+$
309.6

Organic Matter

Inputs

Root

productivity (g

OC $\left.\mathrm{m}^{-2} \mathrm{y}^{-1}\right)$

71.9

84.7

55.6

100.8

(15.1)

4.88

$(1,43)$

0.04

(16.8)

(13.9)

(13.7)

11 month

surface

accretion (g OC

$\left.\mathrm{m}^{-2} \mathrm{y}^{-1}\right)$

235.1

1692

185.18

210.6

(34.2)

10.43

$(1,58)$

0.14

(17.3) (26.3)

22 month

surface

accretion (g OC

$\left.\mathrm{m}^{-2} \mathrm{y}^{-1}\right)$

375
$(72.4)$

554

(73.3)

658.8

(84.5)

363.1

(61.2)

$22.88 \quad 0.43 \quad \mathrm{y}=165.5(\mathrm{p})+$

$(2,57) \quad(<0.001) \quad 244.5(\mathrm{f})+635.1$

\section{Microclimate}




\begin{tabular}{|c|c|c|c|c|c|c|c|}
\hline 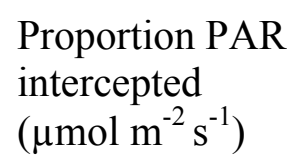 & $\begin{array}{l}17.4 \\
(2.5)\end{array}$ & $\begin{array}{l}85.6 \\
(3.2)\end{array}$ & $\begin{array}{l}52.8 \\
(6.4)\end{array}$ & $\begin{array}{l}50.2 \\
(5.9)\end{array}$ & $\begin{array}{l}171.8 \\
(2,77)\end{array}$ & $\begin{array}{c}0.81 \\
(<0.001)\end{array}$ & $\begin{array}{l}y=72.1(p)-0.2(f)+ \\
97.2\end{array}$ \\
\hline $\begin{array}{l}\text { Temperature } \\
\left({ }^{\circ} \mathrm{C}\right)\end{array}$ & $\begin{array}{l}23.9 \\
(0.1)\end{array}$ & $\begin{array}{l}22.5 \\
(0.1)\end{array}$ & NA & NA & $\begin{array}{l}10.43 \\
(3,13)\end{array}$ & $\begin{array}{c}0.89 \\
(<0.001)\end{array}$ & $\begin{array}{l}y=-0.73(p)+0.003(P)- \\
0.0003\left(P^{2}\right)+23.9\end{array}$ \\
\hline \multicolumn{8}{|l|}{$\begin{array}{l}\text { Aboveground } \\
\text { Organic Matter } \\
\text { Breakdown }\end{array}$} \\
\hline $\begin{array}{l}\text { Wood } \\
\left(k \text { day }^{-1}\right)\end{array}$ & $\begin{array}{c}0.002 \\
(0.0001)\end{array}$ & $\begin{array}{c}0.002 \\
(0.00007)\end{array}$ & $\begin{array}{c}0.002 \\
(0.00009)\end{array}$ & $\begin{array}{c}0.002 \\
(0.00009)\end{array}$ & $\begin{array}{c}14.53 \\
(1,77)\end{array}$ & $\begin{array}{c}0.15 \\
(<0.001)\end{array}$ & $y=-0.000007(P)+0.0002$ \\
\hline $\begin{array}{l}\text { Cellulose } \\
\left(k \text { day }^{-1}\right)\end{array}$ & $\begin{array}{c}0.008 \\
(0.006)\end{array}$ & $\begin{array}{c}0.006 \\
(0.0004)\end{array}$ & $\begin{array}{c}0.003 \\
(0.0002)\end{array}$ & $\begin{array}{c}0.008 \\
(0.0005)\end{array}$ & $\begin{array}{c}16.46 \\
(3,159)\end{array}$ & $\begin{array}{c}0.23 \\
(<0.001)\end{array}$ & $\begin{array}{l}y=-0.001(p)+0.00004(P) \\
-0.002(f)+0.0003\end{array}$ \\
\hline $\begin{array}{l}\text { Mangrove litter } \\
\left(k \text { day }^{-1}\right)\end{array}$ & $\begin{array}{c}0.004 \\
(0.0002)\end{array}$ & $\begin{array}{c}0.006 \\
(0.0003)\end{array}$ & $\begin{array}{c}0.005 \\
(0.0003)\end{array}$ & $\begin{array}{c}0.005 \\
(0.0003)\end{array}$ & $\begin{array}{l}10.17 \\
(2,85)\end{array}$ & $\begin{array}{c}0.2 \\
(<0.001)\end{array}$ & $\begin{array}{l}y=0.0007(p)- \\
0.000009(P)+0.0044\end{array}$ \\
\hline $\begin{array}{l}\text { Marsh litter } \\
\left(k \text { day }^{-1}\right)\end{array}$ & $\begin{array}{c}0.028 \\
(0.004)\end{array}$ & $\begin{array}{c}0.027 \\
(0.003)\end{array}$ & $\begin{array}{c}0.029 \\
(0.004)\end{array}$ & $\begin{array}{c}0.027 \\
(0.002)\end{array}$ & $>0.05$ & NA & NA \\
\hline
\end{tabular}




\section{Belowground}

\section{Organic Matter}

Breakdown

Wood

$\left(k\right.$ day $\left.^{-1}\right)$

$0-15 \mathrm{~cm}$

$\begin{array}{cccc}0.001 & 0.001 & 0.0019 & 0.0009 \\ (0.0001) & (0.0001) & (0.0002) & (0.0001)\end{array}$

Root

$\left(k\right.$ day $\left.^{-1}\right)$

$0-15 \mathrm{~cm}$

0.0042
$(0.0002)$

0.0037

$(0.0002)$

0.0041

(0.0002)

0.0038

$(0.0002)$

Wood

$\left(k\right.$ day $\left.^{-1}\right)$

$15-30 \mathrm{~cm}$

0.00058

$(0.00005)$

0.00065

$(0.00005)$

0.0004

$(0.00003)$

Root

$\left(k\right.$ day $\left.^{-1}\right)$

$15-30 \mathrm{~cm}$ $\begin{array}{cccc}0.0028 & 0.0018 & 0.0023 & 0.0022 \\ (0.0001) & (0.0001) & (0.0001) & (0.00013)\end{array}$
$33.49 \quad 0.52 \quad \mathrm{y}=0.00017(\mathrm{p})+0.0005(\mathrm{f})$

$(2,58) \quad(<0.001)+0.0014$

$$
\begin{aligned}
& \mathrm{y}=-0.0003(\mathrm{p})+0.0007(1) \\
& +0.0000033(\mathrm{P})+ \\
& 0.001(\mathrm{p} * \mathrm{P})+
\end{aligned}
$$

$\begin{array}{lll}4.07 & 0.26 & 0.000008\left(\mathrm{P}^{*} \mathrm{f}\right)+\end{array}$

$(7,53) \quad(<0.001) \quad 0.000009\left(\mathrm{p}^{*} \mathrm{P} * \mathrm{f}\right)$

$\begin{array}{ccc}32.7 & 0.33 \\ (1,61) & (<0.001) & y=0.002(f)+0.0006\end{array}$

$27.78 \quad 0.43 \quad \mathrm{y}=-0.0006(\mathrm{p})-$

$(2,69) \quad(<0.001) \quad 0.000004(\mathrm{P})+0.002$ 
Table 2. Plot weighted average responses to mangrove cover. We identified relationships between plot weighted average values and percent plot mangrove cover. We report either linear or quadratic relationships based on AICc for each response variable.

\begin{tabular}{|c|c|c|c|}
\hline & $\begin{array}{l}\text { F-statistic } \\
\text { (D.F.) }\end{array}$ & $\begin{array}{l}\mathrm{R}^{2} \\
(P \text {-value })\end{array}$ & $\begin{array}{l}\text { Equation } \\
(\mathrm{P}=\text { Plot mangrove cover })\end{array}$ \\
\hline \multicolumn{4}{|l|}{ Organic Matter Stocks } \\
\hline $\begin{array}{l}\text { Aboveground biomass } \\
\left(\mathrm{g} \mathrm{OC}^{-2}\right)\end{array}$ & $\begin{array}{l}61.77 \\
(1,2)\end{array}$ & $\begin{array}{c}0.95 \\
(0.016)\end{array}$ & $y=3.3(P)+168$ \\
\hline $\begin{array}{l}\text { Belowground biomass } \\
\left(\mathrm{g} \mathrm{OC} \mathrm{m}^{-2}\right)\end{array}$ & 8.58 & 0.60 & \\
\hline $0-30 \mathrm{~cm}$ & $(1,4)$ & $(0.043)$ & $y=5.6(P)+507.4$ \\
\hline Surface Soil \% OC & & $\begin{array}{c}\text { NA } \\
(>0.05)\end{array}$ & NA \\
\hline \multicolumn{4}{|l|}{ Organic Matter Inputs } \\
\hline $\begin{array}{l}\text { Root productivity } \\
\left(\mathrm{g} \mathrm{OC} \mathrm{m}^{-2} \mathrm{y}^{-1}\right)\end{array}$ & $\begin{array}{c}0.06 \\
(1,4)\end{array}$ & $\begin{array}{c}\text { NA } \\
(>0.05)\end{array}$ & NA \\
\hline $\begin{array}{l}11 \text { month surface accretion } \\
\left(\mathrm{g} \mathrm{OC} \mathrm{m}^{-2} \mathrm{y}^{-1}\right)\end{array}$ & $\begin{array}{l}14.02 \\
(2,7)\end{array}$ & $\begin{array}{c}0.74 \\
(0.004)\end{array}$ & $\mathrm{y}=-14.5(\mathrm{P})+0.1\left(\mathrm{P}^{2}\right)$ \\
\hline $\begin{array}{l}22 \text { month surface accretion } \\
\left(\mathrm{g} \mathrm{OC} \mathrm{m}^{-2} \mathrm{y}^{-1}\right)\end{array}$ & $\begin{array}{c}0.06 \\
(1,8)\end{array}$ & $\begin{array}{c}\text { NA } \\
(>0.05)\end{array}$ & NA \\
\hline
\end{tabular}




\section{Proportion PAR intercepted}

$\left(\mu \mathrm{mol} \mathrm{m} \mathrm{m}^{-2} \mathrm{~s}^{-1}\right)$

Temperature $\left({ }^{\circ} \mathrm{C}\right)$

\section{Aboveground Organic Matter Breakdown}

Wood $\left(k\right.$ day $\left.^{-1}\right)$

Cellulose $\left(k\right.$ day $\left.^{-1}\right)$

Mangrove litter $\left(k\right.$ day $\left.^{-1}\right)$

Marsh litter $\left(k\right.$ day $\left.^{-1}\right)$

\section{Belowground Organic Matter Breakdown}

Wood $\left(k\right.$ day $\left.^{-1}\right)$

$0-15 \mathrm{~cm}$

$\operatorname{Root}\left(k\right.$ day $\left.^{-1}\right)$

$0-15 \mathrm{~cm}$

Wood $\left(k\right.$ day $\left.^{-1}\right)$

$15-30 \mathrm{~cm}$

$\operatorname{Root}\left(k\right.$ day $\left.^{-1}\right)$

$15-30 \mathrm{~cm}$
$18.85 \quad 0.66$

$(1,8) \quad(0.002) \quad y=0.5(P)+27.04$

$13.84 \quad 0.76$

$(2,6) \quad(<0.006) \quad \mathrm{y}=0.02(\mathrm{P})+0.48\left(\mathrm{P}^{2}\right)$

$\begin{array}{lll}\begin{array}{l}4.69 \\ (1,8)\end{array} & \begin{array}{l}0.29 \\ (0.06)\end{array} & \mathrm{y}=0.000006(\mathrm{P})+0.0023 \\ 5.11 & 0.48 & \mathrm{y}=0.00007(\mathrm{P})+0.0000005\left(\mathrm{P}^{2}\right) \\ (2,7) & (0.04) & +0.0048 \\ 12.58 & 0.56 & \mathrm{y}=0.0004(\mathrm{P})+0.004\left(\mathrm{P}^{2}\right) \\ (1,8) & (0.008) & 0.0058 \\ & \text { NA } & \\ \text { NA } & (>0.05) & \text { NA }\end{array}$

$5.32 \quad 0.42$

$(1,5) \quad(0.07) \quad \mathrm{y}=0.000007(\mathrm{P})+0.0009$

$\begin{array}{ll}8.36 & 0.71\end{array}$

$(2,4) \quad(0.04)$

$\mathrm{y}=0.000031(\mathrm{P})-0.000004\left(\mathrm{P}^{2}\right)+$

$1.21 \quad \mathrm{NA}$

$(2,4) \quad(>0.05) \quad \mathrm{NA}$

$7.49 \quad 0.52$

$(1,5) \quad(0.04) \quad y=-0.00000004\left(P^{2}\right)+0.0024$ 
Table 3. Organic matter stoichiometry. We report mean and standard error of total carbon $(\% \mathrm{C})$, total nitrogen $(\% \mathrm{~N})$ and total phosphorus $(\% \mathrm{P})$ and their molar ratios $(\mathrm{C}: \mathrm{N}, \mathrm{C}: \mathrm{P}, \mathrm{N}: \mathrm{P})$ for litter and roots before (initial) and after field incubation and in surface accretion after 22 months.

\begin{tabular}{|c|c|c|c|c|c|c|}
\hline & $\% \mathrm{C}$ & $\% \mathrm{~N}$ & $\% \mathrm{P}$ & $\mathrm{C}: \mathrm{N}$ & $\mathrm{C}: \mathrm{P}$ & $\mathrm{N}: \mathrm{P}$ \\
\hline $\begin{array}{l}\text { Mangrove litter } \\
\text { (initial) }\end{array}$ & $43.9(0.5)$ & $0.75(0.02)$ & $0.1(0.01)$ & $68.9(2.5)$ & $1088.2(119.6)$ & $15.7(1.3)$ \\
\hline $\begin{array}{l}\text { Marsh litter } \\
\text { (initial) }\end{array}$ & $19.3(0.6)$ & $1.3(0.02)$ & $0.1(0.01)$ & $17.7(0.07)$ & $471.7(39.5)$ & $26.6(2.3)$ \\
\hline $\begin{array}{l}\text { Mangrove litter } \\
\text { (6 months) }\end{array}$ & $36.7(2.4)$ & $1.3(0.08)$ & $0.1(0.01)$ & $34.0(1.1)$ & $1101.4(109)$ & $32.2(2.8)$ \\
\hline $\begin{array}{l}\text { Marsh litter } \\
\text { (6 months) }\end{array}$ & $25.1(3.1)$ & $1.4(0.8)$ & $0.1(0.2)$ & $20.44(2.2)$ & $604.9(14.7)$ & $29.6(3.2)$ \\
\hline $\begin{array}{l}\text { Mangrove root } \\
\text { (initial) }\end{array}$ & $38.4(0.4)$ & $0.7(0.1)$ & $0.06(0.01)$ & $61.3(1.6)$ & $1825.3(277)$ & $29.5(3.8)$ \\
\hline $\begin{array}{l}\text { Marsh root } \\
\text { (initial) }\end{array}$ & $33.7(0.7)$ & $1.1(0.04)$ & $0.2(0.05)$ & $36(1.7)$ & $462.7(93.6)$ & $12.7(2.4)$ \\
\hline $\begin{array}{l}\text { Mangrove root } \\
\text { breakdown } \\
\text { (1 year) }\end{array}$ & $31.6(2.5)$ & $1.3(0.5)$ & $0.06(0.002)$ & $29.6(2.9)$ & $1554.2(46.1)$ & $47(1.5)$ \\
\hline $\begin{array}{l}\text { Marsh root } \\
\text { breakdown (1 year) }\end{array}$ & $28.9(1)$ & $1.2(0.04)$ & $0.06(0.003)$ & $27.1(0.7)$ & $1345.7(91)$ & $43.9(2.3)$ \\
\hline
\end{tabular}


22 month surface

accretion

(mangrove patches)

$5.5(0.8)$

$0.4(0.05)$

$0.08(0.005)$

$14.6(0.8)$

$187.4(17.9)$

$12.67(0.8)$

22 month surface

accretion

(marsh patches)

$2.6(0.4)$

$0.3(0.03) \quad 0.07(0.007)$

$12.1(0.4)$

$102.6(8.7)$

$8.7(0.8)$ 


\section{Figure Legends}

Figure 1 Organic carbon standing stocks A Patch-scale aboveground biomass $(P<0.001)$

B Plot-weighted average aboveground biomass $\left(\mathrm{R}^{2}=0.95 ; P=0.02\right)$ C Patch-scale belowground biomass $(P=0.01) \mathbf{D}$ Plot-weighted average belowground biomass $\left(\mathrm{R}^{2}=0.57 ; P=0.05\right) \quad$ E Patch-scale surface soil $\%$ organic carbon $(P<0.05)$ F Plotweighted average soil \% organic carbon $(P>0.05)$.

Figure 2 Surface organic carbon accretion A 11 month patch-scale treatment by plotscale mangrove cover $\left(\mathrm{R}^{2}=0.52 ; P=0.02\right) \mathrm{B} 11$ month plot-weighted average surface organic carbon accretion $\left(\mathrm{R}^{2}=0.74 ; P=0.04\right) \mathrm{C} 22$ month patch-scale treatment by plot level mangrove cover excluding fringe plots (interior only). Open circles represent marsh patches and their relationship to plot cover is represented by the line of best fit and $95 \%$ confidence intervals $\left(\mathrm{R}^{2}=0.21 ; P=0.02\right)$, black circles represent mangrove patches $\mathrm{D} 22$ month plot-weighted average organic carbon accretion $(P>0.05)$.

Figure 3 Microclimate A PAR interception patch-scale treatment by plot-scale mangrove cover. Black circles represent mangrove patches $\left(\mathrm{R}^{2}=0.34 ; P=0.04\right)$, open circles represent marsh patches $(P>0.05)$ B PAR interception plot-weighted average $\left(\mathrm{R}^{2}=0.74\right.$; $P<0.001)$ C Temperature patch-scale treatment by plot-scale cover. Black circles represent mangrove patches, open circles represent marsh patches $(P>0.05) \mathbf{D}$ Temperature plot-weighted average $\left(\mathrm{R}^{2}=0.74 ; P=0.004\right)$. 
Figure 4 Surface organic matter breakdown A Patch-scale wood standard substrate breakdown $(\mathrm{P}>0.05)$ B Plot-weighted average wood standard substrate breakdown $\left(\mathrm{R}^{2}=\right.$ $0.29 ; P=0.06)$ C Patch-scale cellulose standard substrate breakdown $(P=0.03)$ D Plotweighted average cellulose standard substrate breakdown $\left(\mathrm{R}^{2}=0.48 ; P=0.04\right)$ E Patchscale mangrove litter breakdown $(P=0.04)$ F Plot-weighted average mangrove litter breakdown $\left(\mathrm{R}^{2}=0.66 ; P=0.003\right)$.

Figure 5 Belowground organic matter breakdown $(0-15 \mathrm{~cm})$ A Patch-scale wood standard substrate breakdown $(0-15 \mathrm{~cm})(P=0.03)$ B Plot-scale wood standard substrate breakdown $(0-15 \mathrm{~cm})\left(\mathrm{R}^{2}=0.42 ; P=0.07\right) \mathrm{C}$ Patch-scale root species specific breakdown $(0-15 \mathrm{~cm})(P=0.03)$ D Plot-scale weighted average root species specific breakdown $(0-$ $15 \mathrm{~cm})\left(\mathrm{R}^{2}=0.71 ; P=0.04\right)$.

Figure 6 Belowground organic matter breakdown (15-30 cm) A Patch-scale wood standard substrate breakdown $(15-30 \mathrm{~cm})(P=0.04)$ B Plot-weighted average wood standard substrate breakdown $(15-30 \mathrm{~cm})(P>0.05)$ C Patch-scale root species specific breakdown $(15-30 \mathrm{~cm})(P=0.03)$ D Plot-weighted average root species specific breakdown $(15-30 \mathrm{~cm})\left(\mathrm{R}^{2}=0.52 ; P=0.04\right)$. 


\section{Figure 1.}
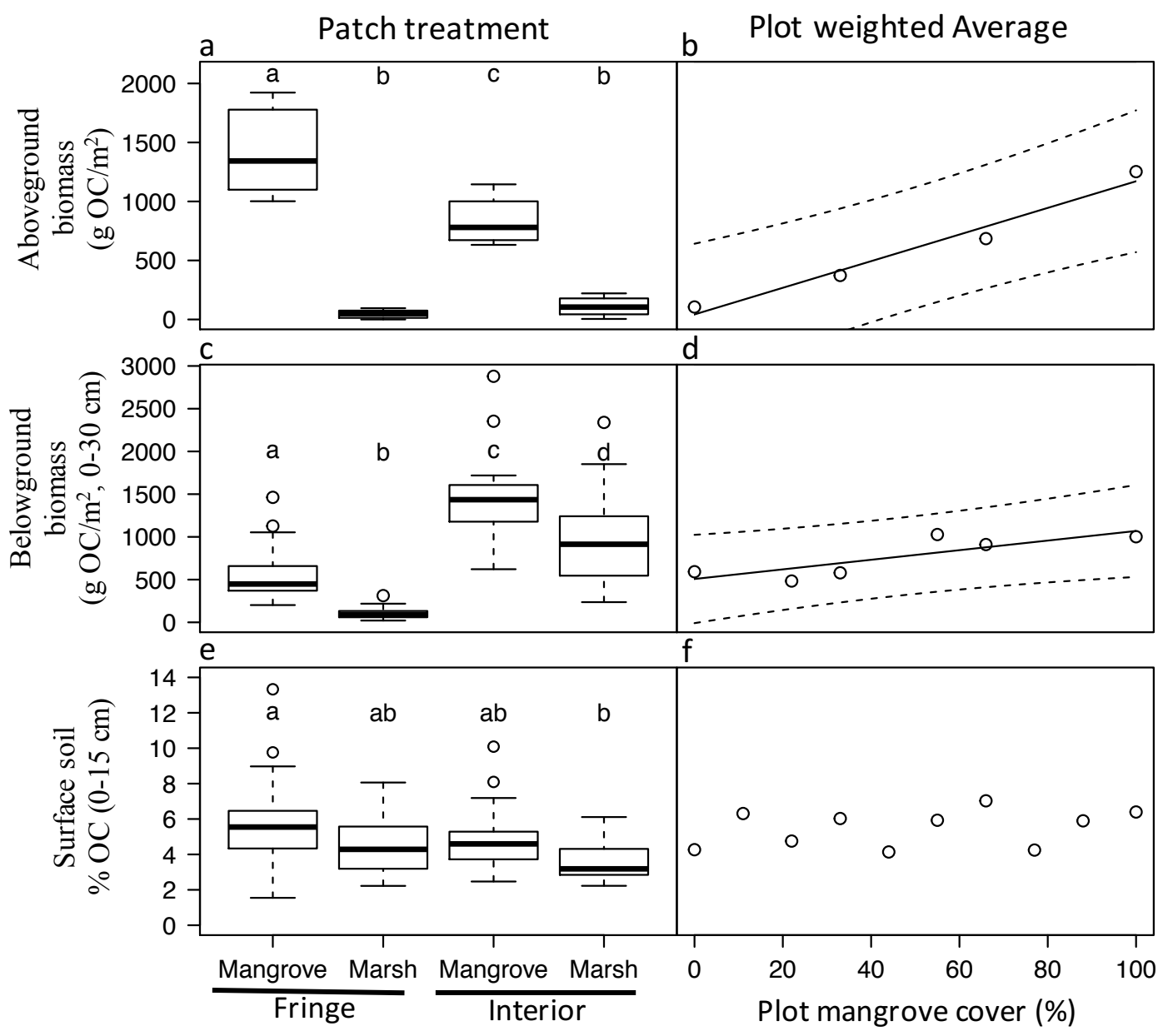


\section{Figure 2.}

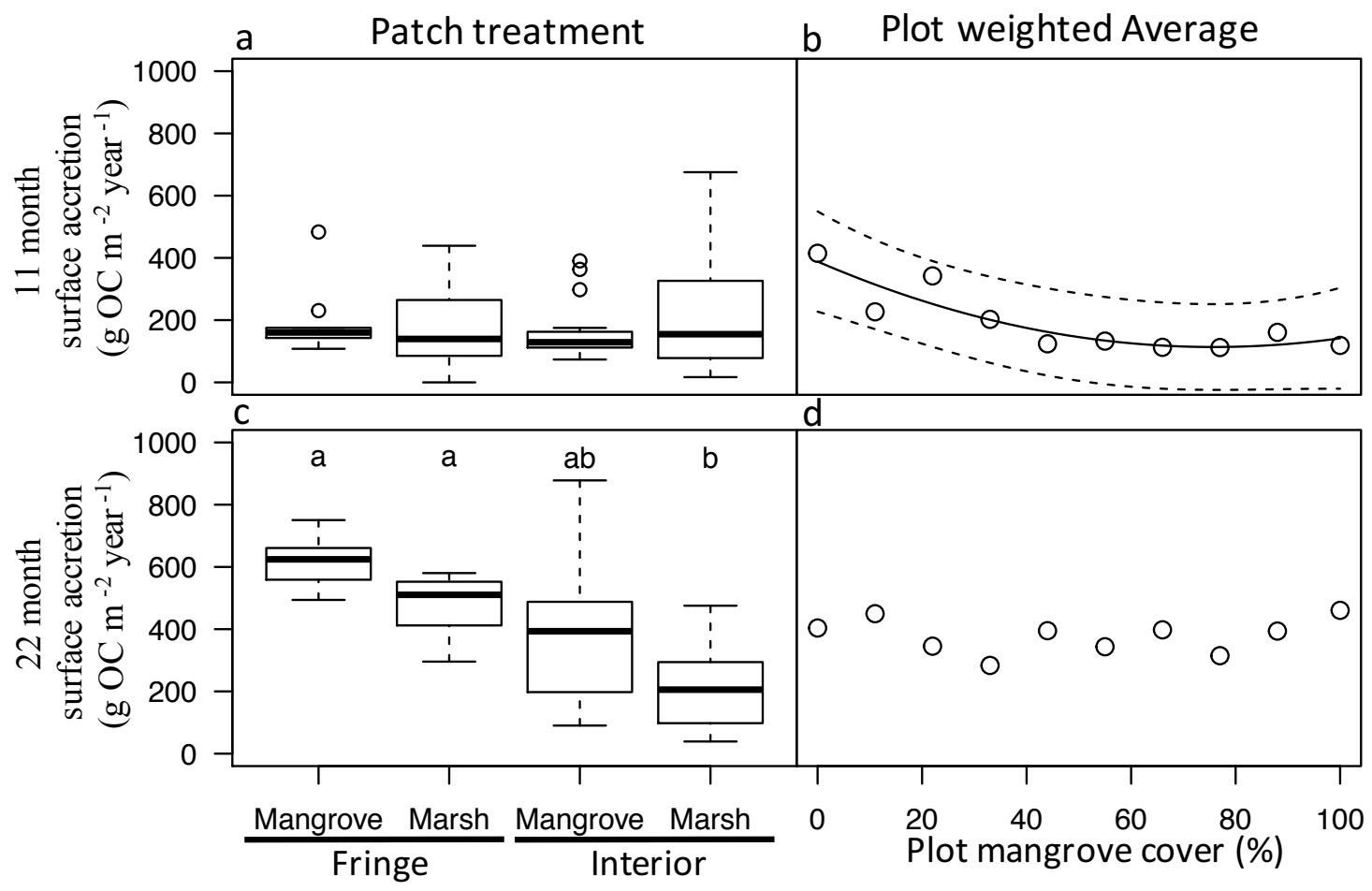


Figure 3.
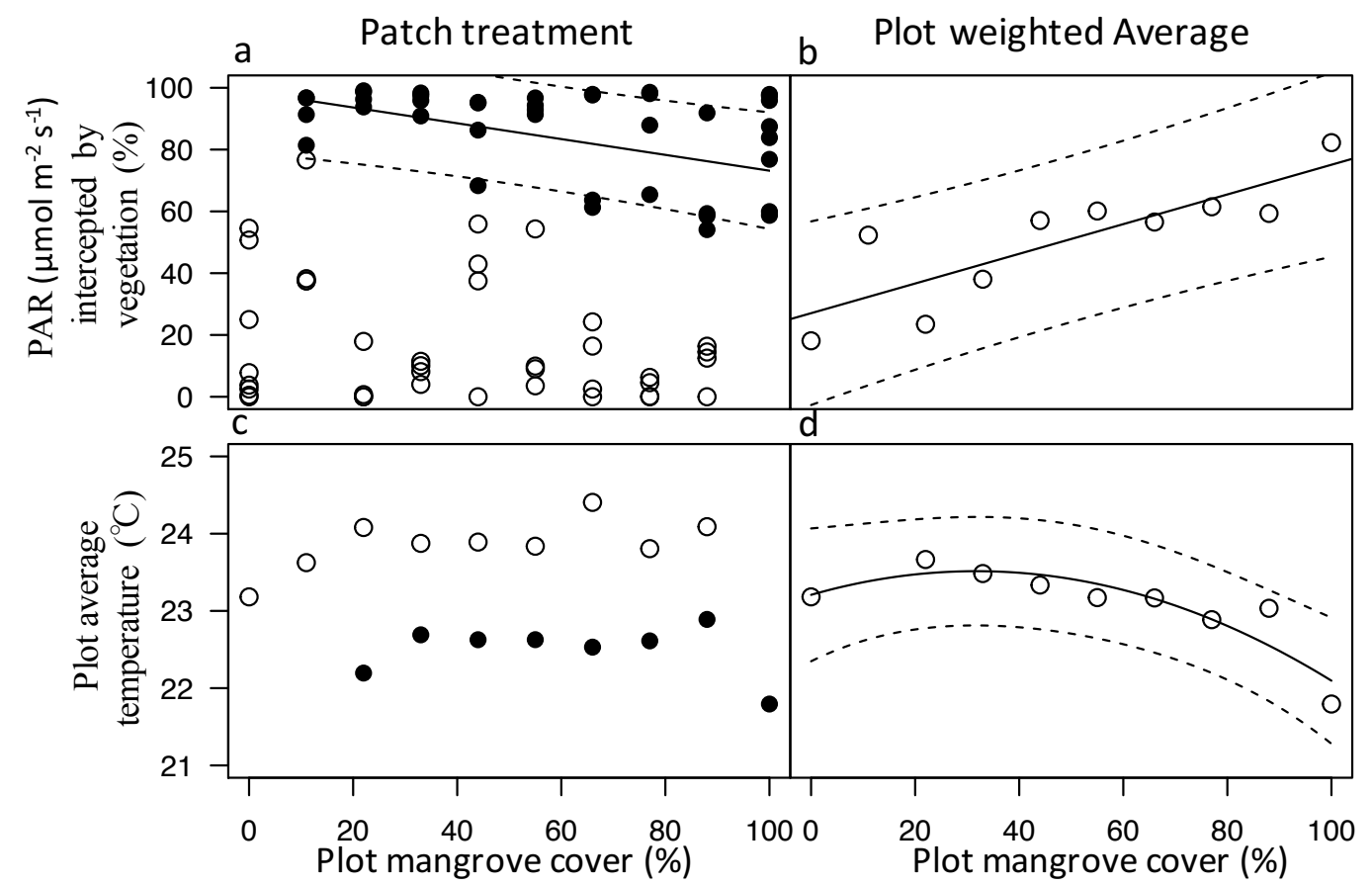
Figure 4.

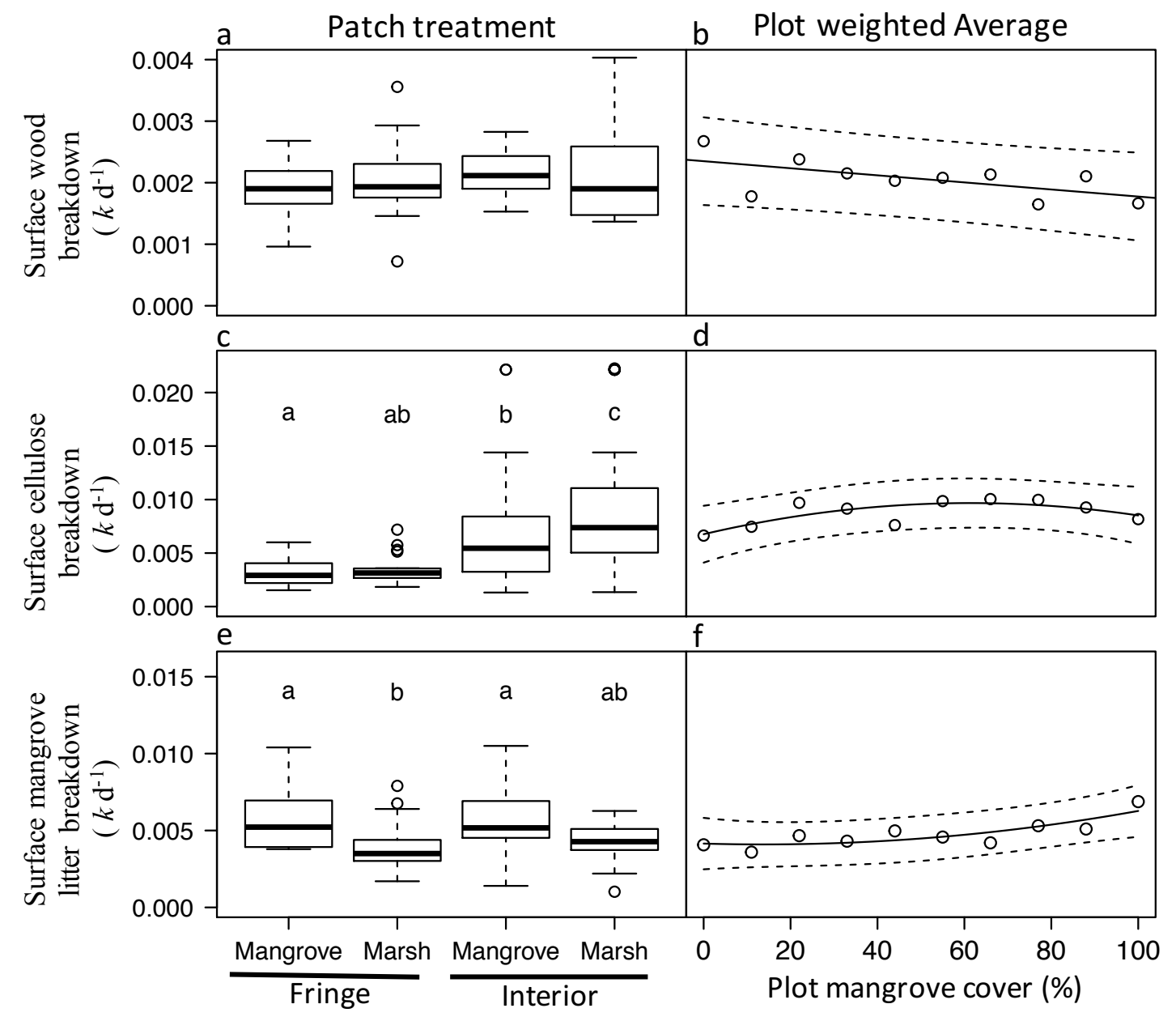




\section{Figure 5.}

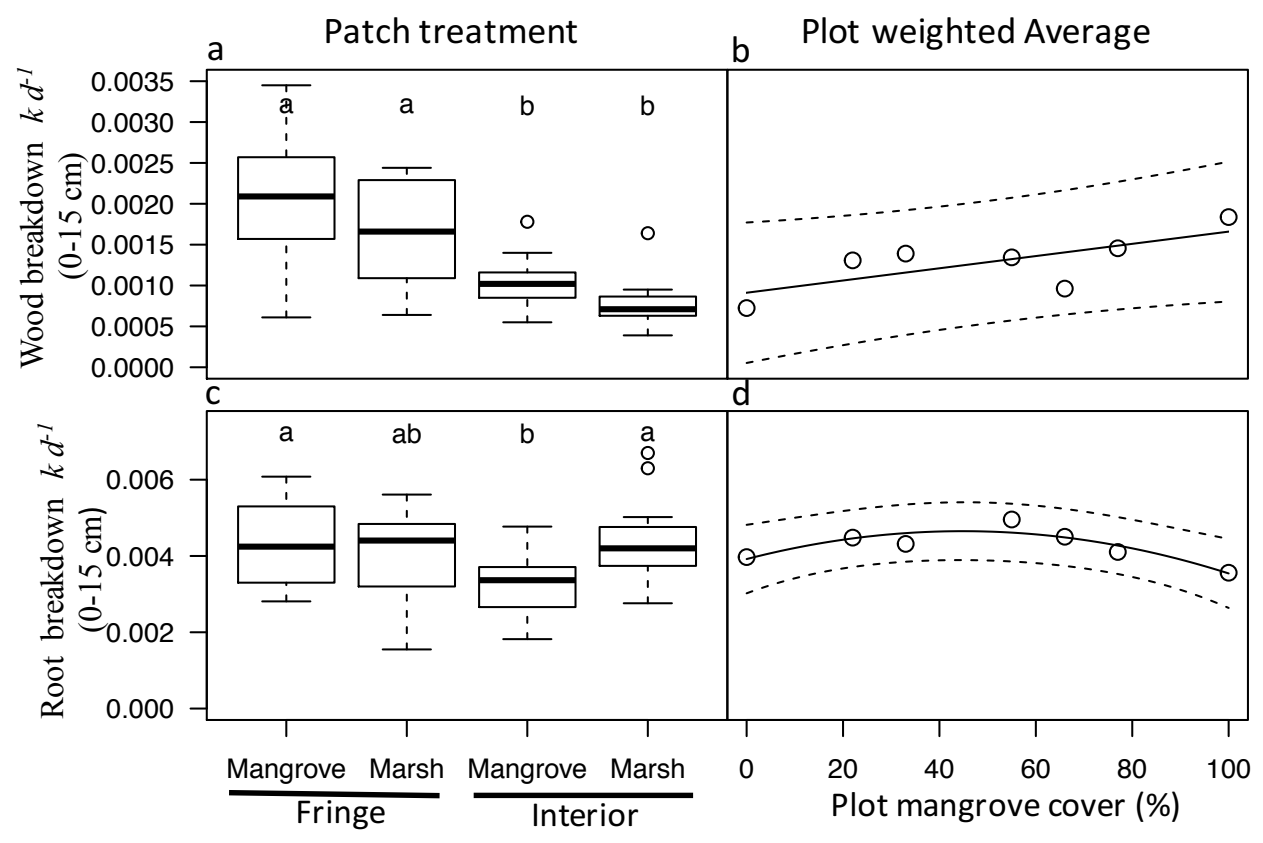


Figure 6.

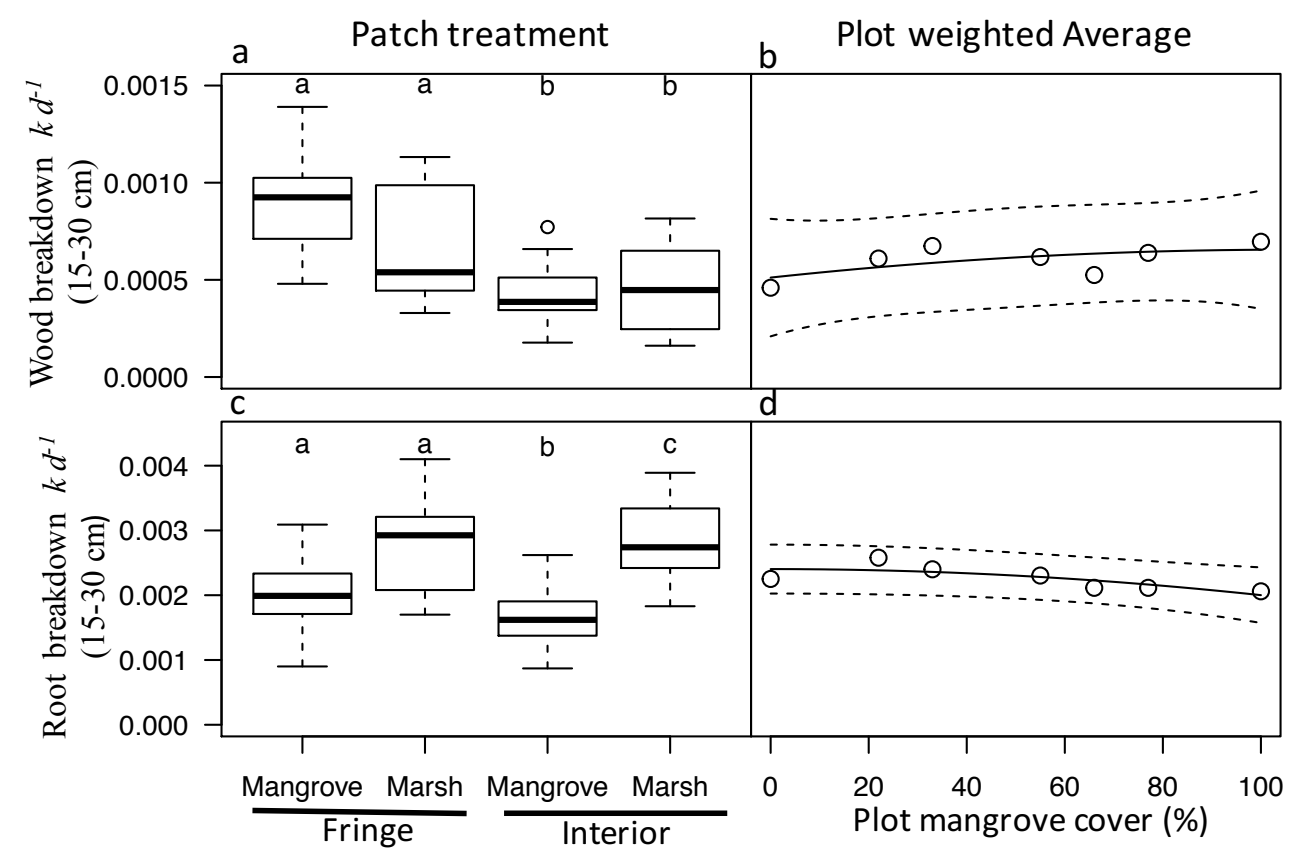


CHAPTER III

SOIL ORGANIC CARBON STOCKS DECREASE WITH SALTWATER INTRUSION DESPITE MANGROVE ENCROACHMENT IN THE FLORIDA COASTAL EVERGLADES 


\title{
Soil organic carbon stocks decrease with saltwater intrusion despite mangrove encroachment in the Florida Coastal Everglades
}

Sean P. Charles, John S. Kominoski, Mike S. Ross, Jay Sah, John F. Meeder, Leonard J. Scinto

\begin{abstract}
Accelerated sea-level rise and freshwater management are drastically altering the structure and function of coastal ecosystems, with uncertain impacts on critical soil carbon storage. Coastal wetlands sequester more atmospheric carbon per unit area than any other ecosystem, largely by storing organic carbon (OC) in soil, providing substrate to increase their soil elevation to keep pace with sea level rise. Saltwater intrusion can affect $\mathrm{OC}$ storage by creating functional changes in existing vegetation communities (altering the balance of OC inputs from productivity or OC loss from decomposition rates), or by driving vegetation shifts. Throughout the tropics and subtropics, saltwater intrusion often drives the inland encroachment of mangrove forests and in the Southeast Saline Everglades the heterogeneous nature of mangrove recruitment provides an ideal template to quantify the interacting impacts of vegetation shifts and saltwater intrusion. We used short-, intermediate-, and long-term response variables to identify structural and functional attributes of ecosystems with differential C storage. We measured soil nutrient chemistry (percent nitrogen, phosphorus and nutrient ratios) and vegetation dynamics (marsh and mangrove cover) and developed models to determine their impact on organic carbon stocks (root biomass and soil organic carbon) and fluxes (root productivity, and organic matter breakdown). Mangrove cover was negatively related to distance from the
\end{abstract}


coast, but mangrove recruitment was heterogeneous, whereas soil nitrogen, $\mathrm{N}: \mathrm{P}$ and $\mathrm{C}: \mathrm{N}$ ratios increased toward the wetland interior. Soil OC stocks were highest inland, and decreased toward the coast, indicating that saltwater intrusion may decrease soil $\mathrm{C}$ storage. Organic matter breakdown rates were positively related to soil $\mathrm{C}: \mathrm{N}$ ratios, and higher soil $\mathrm{C}: \mathrm{N}$ ratios were measured in inland relative to coastal wetlands, providing indirect evidence that interior marshes are currently experiencing carbon loss as a result of saltwater intrusion. Although saltwater intrusion may be reducing soil organic carbon, mangrove vegetation enhances both root biomass stocks and inputs from root productivity, but did not impact breakdown rates, indicating that mangroves may limit soil carbon loss. Soil organic carbon develops over long time frames, and saltwater encroachment can rapidly destabilize soil organic carbon stocks, and although mangroves may enhance root carbon storage, we did not find a relationship between root processes and overall soil carbon stocks.

\section{INTRODUCTION}

Accelerated sea-level rise (SLR) is causing drastic changes to the structure and function of coastal wetlands. Saltwater intrusion is expected in many freshwater ecosystems as SLR increases (Rahmstorf 2007; Milne et al. 2009), climate change alters temperature and precipitation patterns (Smith et al. 2005; Mily et al. 2005), and anthropogenic alterations upstream continue to reduce freshwater flows to coastal wetlands (Meehl et al. 2007). Additionally, global changes are causing major shifts in plant communities worldwide (Chen et al. 2011), and saltwater intrusion is expected to lead to the replacement of freshwater marsh communities with halophytic species (Sutter 
et al. 2013). In tropical and subtropical ecosystems, saltwater intrusion can cause mangroves to move inland and displace herbaceous marshes, as has been observed in Australia (Rogers et al. 2000, 2006; Winn et al. 2006), Mexico (Lopez-Medellin et al. 2011), and the United States (Ross et al. 2000; Krauss et al. 2011; Smith et al. 2013; Guo et al. 2017). Any shifts in coastal wetland C storage associated with these changes will have profound impacts locally on marsh resilience, and globally on the sequestration of $\mathrm{CO}_{2}$, yet we lack a clear understanding of the impact of shifts in hydrologic conditions and foundation plant species.

Shifts between plant communities with drastically different traits are likely to alter ecosystem function (Kominoski et al. 2013). One of the most distinct vegetation shifts across landscapes worldwide is the encroachment of woody vegetation into grasslands (Van Auken 2000; Frelich and Reich 2010; Knapp et al. 2008; Saintilan et al. 2015). Vegetation changes may influence $\mathrm{C}$ cycling through effects on productivity, litter chemistry, microclimate, capture of allochthonous inputs and soil aeration (Furukawa et al. 1997; Bowman et al. 2004; Lovett et al. 2004; Wittman et al. 2004; Fagherazzi et al. 2006), and in terrestrial ecosystems woody encroachment generally leads to increased soil C storage (Elridge et al. 2011). In coastal wetlands, differences in the impact of marsh and mangrove $\mathrm{C}$ storage is uncertain (Kelleway et al. 2017). In sediment-poor coastal wetlands like the Southeast Saline Everglades (Figure 2), organic matter dynamics drive elevation change, particularly through the production and accumulation of roots (Hatten et al. 1983; Nyman et al. 1993; Turner et al. 2001; Delaune and Pezeshki 2002). 
The interactive effects of mangrove encroachment and saltwater intrusion on soil OC storage are uncertain. Mangrove and saltmarsh ecosystems store soil OC at similar rates globally (Chmura et al. 2013) and when comparing adjacent mangrove and saltmarsh ecosystems, some studies have found greater soil C storage capacity in mangroves (Bianchi et al. 2013; Yando and others 2016; Charles et al. in review), while others have found no difference (Perry and Mendelssohn 2009; Henry and Twilley 2013; Doughty and others 2015; McKee et al. 2017). Independently, saltwater intrusion can drive loss of soil OC by decreasing plant productivity and biomass with salt stress (e.g., Krauss et al. 2009; Neubauer 2008), and cause major biogeochemical changes that often lead to enhanced breakdown of soil organic matter (Weston et al. 2006; Neubauer 2013; Chambers et al. 2013). However, in many coastal wetlands in the tropics and subtropics, saltwater intrusion may also drive the landward encroachment of mangroves into wetlands previously dominated by freshwater and brackish marsh species. Although mangrove encroachment into wetland interior has happened broadly across the Everglades, fire, disturbances, propagule distribution, and underlying habitat characteristics (Smith et al. 2012) limit mangrove recruitment, thus creating a patchwork of vegetation across a landscape experiencing saltwater intrusion.

The Florida Coastal Everglades are particularly susceptible to saltwater intrusion from sea-level rise due to low elevation and slope (Titus and Richman 2001), porous limestone bedrock, and a series of $2500 \mathrm{~km}$ of canals and water control structures that greatly reduce natural freshwater availability (Sklar et al. 2000; McVoy et al. 2011). Everglades, plant communities are oriented in zones according to their salinity tolerance. Glycophytic communities dominated by Cladium jamaicense occupy inland areas 
through competitive advantages in freshwater environments, mangrove species dominated by Rhizophora mangle prevail nearer to the coast due to salt tolerance, and the ecotone between the two is occupied by mixed graminoid-mangrove communities (Egler 1952; Koch 1996; Ross et al. 2000). Between 1940 and 1994, the mixed graminoidmangrove community moved inland $3.3 \mathrm{~km}$ and was replaced by stands of $R$. mangle (Ross et al. 2000), a pattern identified elsewhere in the Everglades as well (Krauss et al. 2011; Smith et al. 2013). Saltwater intrusion along the Everglades ecotone has also increased P availability (Sandoval et al. 2016), often temporarily increasing sawgrass productivity, but reduces productivity even below 5 ppt (Macek and Rejmankova 2007; Wilson et al. 2015), and kills sawgrass vegetation when salinity averages around $15 \mathrm{ppt}$ (Troxler et al. 2014). Unless halophytes (particularly mangroves) can replace glycophytes, root death can lead to rapid loss of root biomass and soil carbon, driving a decrease in elevation and greater inundation (Delaune et al. 1994), potentially making future plant establishment impossible. In the Southeast Everglades, an interior band of sparse vegetation - the "white zone" (Ross et al. 2000; Egler 1952) has expanded into what was previously denser-canopied freshwater marsh (Figure 2).

We selected wetlands along coastal gradients in the Southeast Saline Everglades a region with rapid changes in vegetation cover (Ross et al. 2000) - to quantify the impacts of shifting vegetation, saltwater intrusion and underlying soil characteristics on stocks and fluxes of belowground carbon. As saltwater intrudes into the Everglades interior, mangrove colonization of the landscape is spatially variable and heterogeneous, providing a unique opportunity to quantify the impacts of saltwater intrusion with and without concomitant vegetation shifts. We used short- (organic matter fluxes that 
manifest rapidly), intermediate- (development of root biomass that requires vegetation establishment and development), and long-term response variables (soil organic carbon that changes over decades to centuries) to identify structural and functional attributes of ecosystems with differential C storage (Figure 1). We compared OC fluxes and stocks to shifting vegetation (vegetation species, cover, height), environmental characteristics (soil depth, type, nutrient and organic matter content) and distance to the coast (a proxy for shifting marine connectivity) to quantify drivers and effect across the landscape. We predicted that proximity to the coast would alter soil nutrient characteristics due to low $\mathrm{P}$ availability in the Everglades interior interacting with marine P subsidies (Figure 1), and that mangrove cover would be higher greater to the coast. We predicted that increasing marine influence on soil would increase breakdown rates, ultimately decreasing OC storage, but the establishment of mangroves would lead to greater root biomass and productivity (Figure 1). We predicted that increasing mangrove cover would increase root productivity and biomass stocks, whereas soil characteristics associated with saltwater intrusion would drive increased breakdown and a decrease in soil OC storage (Figure 1). Ultimately we predicted that OC stocks would decrease in marine influenced coastal soils in the absence of mangrove encroachment, but that mangrove cover would increase OC storage, with the ultimate fate of soil carbon in a more marine influenced coastal wetland to be determined by establishment of mangrove cover (Figure 1). Our results will help to identify the functional differences driven by vegetation dynamics from those driven by larger scale biogeochemical changes associated with saltwater intrusion and to pinpoint conditions that contribute to OC storage, vulnerability to loss of OC and inundation by rising seas 


\section{METHODS}

\section{Experimental Design}

We created 5 transects across the Southeast Saline Everglades that provide a gradient across the marsh-mangrove ecotone. Our study included 19 sites distributed across the Southeast Saline Everglades. Included in the gradient are the lower and upper portions of the white zone, the "incipient" white zone (Ross et al. 2000; 2002) and the distal edge of the freshwater marsh for a total of 24 sites (Figure 2).

\section{Vegetation and soil dynamics with proximity to coast}

At each of the 19 sites we identified and estimated the aboveground cover of vascular plant species rooted within $301-\mathrm{m}^{2}$ plots distributed along a $50 \mathrm{~m}$ radius circle (Ross et al 2000). The design allowed us to identify larger vegetation patterns, as well as heterogeneity within the larger landscape. Plant species cover at each site was characterized based on $1-\mathrm{m}^{2}$ vegetation plots. We combined species cover to represent total vegetation cover, total mangrove cover and total marsh (graminoid) cover for each plot and site.

At the center of each site, we extracted one soil core $(15 \mathrm{~cm}$ diameter $\bullet 30 \mathrm{~cm}$ deep) to determine soil nutrient content. Cores were taken to the lab and sectioned based on visually apparent horizon shifts. All samples were dried at $40^{\circ} \mathrm{C}$ to constant weight to determine dry mass, and then ground using an 8000-D ball mill (Spex SamplePrep, Metuchen, New Jersey, USA). Soil cores were separated into soil 0-15 and 15-30 cm

deep sections. Percent total carbon $(\% \mathrm{C})$ and total nitrogen $(\% \mathrm{~N})$ were determined using a Carlo Erba NA 1500 CHN Analyzer (Carlo Erba, Milan, Italy). Percent total 
phosphorus (\%P) was determined by the ash/acid extraction method (Allen 1974), followed by spectrophotometric analysis. We calculated total nutrient ratios (C:N, C:P, $\mathrm{N}: \mathrm{P})$ using molar mass.

\section{Organic matter fluxes}

We measured organic matter fluxes as root productivity and the breakdown of standardized organic matter within a subset of 12 of our 19 sites. We measured root productivity as ingrowth by inserting a mesh bag filled with commercial peat moss in holes created by belowground biomass cores (McKee et al. 2007). Root ingrowth bags were retrieved after 6-12 months in the field, based on access to sites (helicopter scheduling). Roots were separated from the ingrowth bags, dried and weighed. Root productivity was standardized to represent $\mathrm{kg}$ root $\mathrm{OC} \mathrm{m}^{-2} \mathrm{y}^{-1}$. We tested breakdown rates for labile (cellulose) and recalcitrant (wood) OM, using standard substrates on the soil surface and at two depths in the soil. Adjacent to each root ingrowth experiment, we measured the breakdown of wood and cellulose standard substrates on the soil surface, and at 10-15 $\mathrm{cm}$ and $15-30 \mathrm{~cm}$ depths in the soil. After incubation in the field for 8-16 months, we returned all OM breakdown samples to the laboratory on ice, rinsed them of sediment, and dried the samples at $40^{\circ} \mathrm{C}$ until their mass stabilized. We estimated breakdown rate, $k$, using a linear regression of the ln-transformed fraction of AFDM remaining vs. time (negative exponential model; sensu Benfield 2006). The specific model used was $M_{d}=M_{0} \bullet e^{-k t}$, where $M_{0}$ is the initial litter mass, $M_{t}$ is the litter mass on a given sampling day, and $d$ is number of days of incubation). In addition, we used data from a NOAA local temperature station $\left(\mathrm{N} 25.3903^{\circ}, \mathrm{W}-80.6803\right)$ to determine average 
daily temperature and degree days (days of incubation $\bullet$ degree $\mathrm{C}$ ) throughout the incubation period. To examine breakdown as a function of temperature, we also calculated breakdown as $M_{d d}=M_{0} \bullet e^{-k d d}$, where $d d$ is degree days.

\section{Organic carbon stocks}

We extracted three soil cores to determine organic carbon stocks OC $(15 \mathrm{~cm}$ diameter $\bullet 30 \mathrm{~cm}$ deep) from each site (from the center, most northern and southern vegetation plots). We measured bulk density and calculated percent OC from ash-free dry mass (AFDM) as loss on ignition in a muffle furnace at $550^{\circ} \mathrm{C}$ for $5.5 \mathrm{~h}$ (Karam 1993), and converted to \%OC by dividing by 2 (Pribyl et al. 2010).

At each site, we also took three root biomass cores $(15 \mathrm{~cm}$ diameter $\bullet 30 \mathrm{~cm}$ deep) adjacent to soil OC cores. Root biomass cores were transported to the lab, where living roots were separated from the bulk soil, dried at $40^{\circ} \mathrm{C}$. We calculated root biomass and root $\mathrm{OC}$ content with the same methods as soil OC.

\section{Data analyses}

We created models to determine relationships between proximity to the coast and soil (\%OM, $\% \mathrm{P}, \% \mathrm{~N}, \% \mathrm{C}, \mathrm{CP}, \mathrm{CN}$ and $\mathrm{NP})$ and vegetation (cover of red mangrove, total mangrove cover, cover of marsh and total cover) characteristics. We created a second set of models to determine how soil carbon stocks (root biomass, soil OC) and fluxes (root productivity and breakdown of organic matter standard substrates) are driven by soil and vegetation characteristics. Each response and predictor variable was normalized by the 
equation variable $=(x-\operatorname{mean}(x)) / \operatorname{stdev}(x)$, to insure normality and to provide similar scales. We used hierarchical linear mixed-effects models using the R package "Ime4" (Bates et al. 2015) to test for relationships between response variables and fixed effects (distance to coast and soil and vegetation characteristics), and random effects of transects nested within region. We calculated Akaike's information criterion corrected for small sample size $\left(\mathrm{AIC}_{\mathrm{c}}\right)$ to determine the most parsimonious model from our combination of vegetation, soil and (Hurvich and Tsai 1989). We used an alpha level of 0.05 to determine significant relationships. We used the "MuMIn" package in R (Barton 2016) to determine goodness of fit (conditional $\mathrm{R}^{2}$; Nakagawa and Schielzeth 2013) for top models.

We used piecewise structural equation models (Lefcheck 2016) to measure linkages between proximity to the coast, vegetation and soil chemical characteristics, soil carbon fluxes (root productivity and organic matter breakdown rates) and soil carbon stocks (root biomass and soil organic carbon content). Piecewise structural equation models permit the use of linear mixed effects models, which were essential for dealing with spatial correlation in our study design (Lefcheck 2016). The corresponding model list is composed of linear mixed effects models (individual statistical output described in table 1), run with the R package "Ime4". We ran the model in R with the package “piecewiseSEM." We identified the most parsimonious overall model and removed linkages to minimize AICc. We show only significant correlations $(P<0.05)$ as standardized path coefficients. All analyses were performed using R (version 3.3.2, R Core Team 2016). 


\section{RESULTS}

\section{Vegetation and soil dynamics with proximity to coast}

We found a negative relationship between distance from coast and percent mangrove cover (Figure 3a; Table 1; $P=0.049 ; \mathrm{R}^{2}=0.19$ ), but no relationship to marsh cover $(P>0.05)$. In the soil we found a positive relationship between distance to coast and surface $(0-15 \mathrm{~cm}) \% \mathrm{~N}$ (Figure $3 \mathrm{~b}$; Table $\left.1 ; P=0.01 ; \mathrm{R}^{2}=0.35\right)$, and surface $\% \mathrm{OM}$ $\left(P<0.0001 ; \mathrm{R}^{2}=0.65\right)$, but no relationship between $\% \mathrm{P}$ or $\% \mathrm{C}(P>0.05)$. Surface $\mathrm{C}: \mathrm{N}$ ratios decreased with distance to the coast (Figure $3 \mathrm{c}$; Table $1 ; P=0.01 ; \mathrm{R}^{2}=0.34$ ), while surface N:P ratios increased (Figure 3d; Table 1; Table 1; $P=0.03 ; \mathrm{R}^{2}=0.55$ ). There were no significant relationships between distance to coast and soil characteristics in the deeper soil layer $(>15 \mathrm{~cm})$.

\section{Organic matter fluxes}

Root productivity was best described by a model that only included mangrove cover, which showed a positive relationship (Figure $4 \mathrm{a}$; Table $1 ; \mathrm{R}^{2}=0.30 ; P=0.001$ ). However, a model that included mangrove cover and soil N:P ratio created a similarly parsimonious model (delta AICc $<2$; Burnham and Anderson 2002), with significant negative impact of soil N:P $(P=0.04)$, and explained more variance (Table $\left.1 ; \mathrm{R}^{2}=0.38\right)$. Root productivity did not show significant relationships with any other soil characteristics $(P>0.05)$.

When incubated on the soil surface, neither cellulose nor wood standard substrate breakdown rates $\left(k \mathrm{dd}^{-1}\right)$ were related to vegetation parameters, or soil chemical characteristics $(P>0.05)$. 
Belowground, breakdown rates were positively related to soil $\mathrm{C}: \mathrm{N}$ ratio. Wood standard substrates were positively related to C:N ratios in the shallow soil (Figure 4b; Table $\left.1 ; P=0.04 \mathrm{R}^{2}=0.66\right)$ and deeper $(15-30 \mathrm{~cm})$ soil $\left(\right.$ Table $\left.1 ; P=0.03 \mathrm{R}^{2}=0.36\right)$. In addition, cellulose breakdown was positively related to soil $\mathrm{C}: \mathrm{N}$ ratio in deeper soil (Table $1 ; P=0.04 \mathrm{R}^{2}=0.36$ ). Though it was not included in the most parsimonious model, wood breakdown was positively related to distance from coast in deeper soil $(P=$ $\left.0.03 ; \mathrm{R}^{2}=0.14\right)$. Breakdown rates were not related to mangrove cover, nor were they related to any other nutrient concentrations or ratios.

\section{Organic carbon stocks}

The best predictor of root biomass $(0-30 \mathrm{~cm})$ was Rhizophora mangle (red mangrove) cover (Figure 5a; Table $1 ; \mathrm{R}^{2}=0.58 ; P<0.001$ ). In addition, root biomass was negatively related to soil N:P ratio $\left(\mathrm{R}^{2}=0.34 ; P=0.04\right)$, though this relationship did not improve our model.

Surface soil OC $(0-15 \mathrm{~cm})$ was positively related to distance from coast (Figure $3 \mathrm{~b}$; Table1; $\left.\mathrm{R}^{2}=0.62 ; P<0.001\right)$, but there was no relationship with deeper soil $(P>$ 0.05). In addition, there was no relationship between soil OC to vegetation coverage at the surface or in deeper soil $(P>0.05)$. Finally, we tested the interacting effects of mangrove cover and distance to coast on soil organic carbon stocks. While decreased model parsimony $\left(\mathrm{AICC}=-22.47 ; \mathrm{R}^{2}=0.65\right)$, mangrove cover created a nearsignificant increase in soil OC stocks $(P=0.06)$. 


\section{Structural equation model}

Our piecewise structural equation model illustrates the direct and indirect contributions of proximity to coast on organic carbon stocks and fluxes (Figure $6 ; \mathrm{K}=17$; Fisher's $\mathrm{C}$ value $=25.78 ; P=0.004)$. Path coefficients demonstrate that proximity to coast has a greater (or more consistent) impact on soil chemistry $(\mathrm{N}: \mathrm{P}=-0.38 ; P<0.001$ ; $: \mathrm{N}=0.6 ; P<0.001)$ than on mangrove cover $(0.19 P=0.05)$, demonstrating heterogeneity of mangrove recruitment. Path coefficients show that mangroves explain about half of variation in root productivity $(0.51 ; P=0.001)$ and root biomass $(0.56 ; P=$ $0.002)$. Soil $\mathrm{N}: \mathrm{P}$ ratio decreased root productivity $(-0.3 ; P=0.05)$, and $\mathrm{C}: \mathrm{N}$ ratios increased wood breakdown $(0.43 ; P<0.001)$. Finally, path coefficients show a strong negative impact on surface soil OC stock $(-0.79 ; P<0.001)$, but no impact of our measured OC fluxes or root biomass.

\section{DISCUSSION}

\section{Saltwater intrusion and mangrove encroachment}

We identified strong and consistent shifts in soil chemistry and significant, but more heterogeneous changes in mangrove cover across the study gradient, with no impact on overall vegetation cover. Surface $\% \mathrm{~N}$ in the surface soil increased consistently toward the freshwater interior (Figure 3a), and N:P ratios followed the opposite pattern (Figure $2 b)$ ratios consistently decreased with proximity to the coast. Saltwater intrusion generally drives an increase in P availability throughout the coastal Everglades (Sandoval et al. 2016), because P is more available in seawater in this "upside-down estuary" (Childers et al. 2006). Furthermore, as saltwater intrudes into freshwater marshes, $P$ 
adsorbed to sediment and limestone bedrock, is rapidly released, providing a pulse of $\mathrm{P}$ (Price et al. 2010; Flower et al. 2016; 2017). Although N:P ratios shifted along our coastal gradient, we found no significant change in total soil P, probably due to the Southeast Everglades' proximity to the P-limited and microtidal Florida Bay rather than the more productive Atlantic and Gulf Coasts (Childers et al. 2006).

Inland encroachment of mangroves is heterogeneous and likely slow in carbonate coastal wetlands. Percent cover of $R$. mangle was negatively related to distance to coast in our study (Figure 3a), yet mangrove cover was heterogeneous and the impact of proximity to coast was weaker than that for soil nutrient change (Figure 6). Furthermore, within our study area red mangroves have increased $44 \%$ in the last twenty years while sawgrass marshes declined 15\% (Ross et al. in prep), indicating that interior wetlands are becoming increasingly influenced by saltwater through time. However, in coastal regions with low plant biomass like the Southeast Saline Everglades, saltwater intrusion continues to rapidly expand (Ross et al. 2000), and mangrove cover does not appear to be replacing retreating freshwater vegetation in these wetlands. Encroachment of freshwater and brackish marsh with salinity tolerant species has been identified globally (Sutter et al. 2013; Herbert et al. 2015), and in other subtropical and tropical, mangroves encroachment into freshwater ecosystems has been observed in Australia (Rogers et al. 2000, 2006; Winn et al. 2006), Mexico (Lopez-Medellin et al. 2011), and the United States (Ross et al. 2000; Smith et al. 2013). On the west coast of Florida, between 1927 and 2005, mangroves expanded their range inland by $35 \%$ at the expense of marsh (Krauss et al. 2011). However, in our study area, the encroachment of mangroves has been patchy and associated with the expansion of the low biomass "white zone." The 
patchy nature of recruitment, coupled with widespread shifts in soil chemistry allows us to determine the impacts of saltwater intrusion with and without mangrove encroachment, and may have profound impacts on similar ecosystems globally.

Coastal wetlands are particularly vulnerable to shifts in hydrology, because they are located at the intersection of marine and freshwater ecosystems. The combination of SLR and reduced freshwater availability drives alterations in the balance of fresh and marine water (Dessu et al. 2018), and created widespread saltwater intrusion into freshwater and brackish wetlands (Ross et al. 2000; White and Kaplan 2017). Because much of the Everglades is less than $1.5 \mathrm{~m}$ above sea level (Titus and Richman 2001). Given 1- 2 m of projected SLR (Haigh et al. 2014) this century, widespread saltwater intrusion throughout the Everglades is likely, altering soil and water chemistry and driving widespread shifts in vegetation communities, particularly around our study area in the Southeast Saline Everglades ecotone (Ross et al. 2000).

\section{Saltwater intrusion effects on organic carbon stocks and fluxes}

We predicted that organic matter breakdown rates would be positively related to marine influence, yet we found a positive indirect relationship between organic matter breakdown and freshwater conditions (Figure 6). Added phosphorus frequently drives increased breakdown rates in peat soils (Davis 1991; Newman et al. 2001; Qualls and Richardson 2008). In a mesocosm experiment testing the impact of saltwater encroachment, phosphorus additions increased breakdown rates of leaf-litter (18\%), and roots (11\%) (Charles et al. in prep). However, across the Southeast Saline Everglades, a lack of spatial trends in phosphorus concentrations, and dominance of low organic matter 
marl soils, likely limits the impact. This may also be because many of these wetlands have experienced some saltwater intrusion in the past. Phosphorus adsorbed to limestone is often released immediately upon saltwater intrusion (Flower 2016; 2017). Therefore, limestone near the coast may have released their available phosphorus, and the low levels of OC in these coastal wetlands may indicate that OC breakdown from saltwater encroachment has already peaked and low OC availability may limit breakdown in coastal wetlands, limiting any potential response. Although our results indicate that saltwater intrusion is not increasing breakdown rates, it may mean that higher OC interior wetlands are undergoing changes to become similar to the low $\mathrm{OC}$ wetlands closer to the coast.

We found that vegetation cover did not have a relationship to breakdown rates at the surface or either depth. Other studies have found that mangroves can influence breakdown rates by priming the soil with root exudates (Kuzyakov 2010; Bernal et al. 2016) and particularly in the case of wetland plants like mangroves, by aerating soils with their roots (Gill and Tomlinson 1977). Mangroves can also decrease breakdown rates by by creating shade from their canopy and reducing soil temperature (D'Odorico et al. 2013; Charles et al. in review). In our study, vegetation cover did not influence organic matter breakdown, potentially through a balance between positive and negative impacts of mangrove vegetation on organic matter breakdown.

Priming of recalcitrant organic matter is a globally important process in driving organic matter breakdown (Guenet et al. 2018). There is debate on the influence of nutrients on priming, with two main schools of thought, 1) that nutrients increase soil OM breakdown by providing microbes with nutrients for growth, or 2) that microbes decompose OM 
faster in nutrient-poor conditions to "mine" for nutrients (Craine et al. 2009). However, there may be differential responses depending on OM quality, and microbial $k$ strategists often mine nutrients and thus do not increase breakdown with nutrient addition (Chen et al. 2014).

Increasing mangrove cover increased root productivity and root biomass standing stocks across coastal wetlands. Roots and rhizomes are the primary sources of SOM, C storage and soil elevation change in coastal wetlands (Twilley 1999; McKee et al. 2007; Chmura 2011; Deegan et al. 2012) and in our study mangroves explained about 50\% of all variance in root OC stocks and inputs (Figure 6). Because mangroves increased stocks of root $\mathrm{OC}$ and did not impact organic matter breakdown rates, it is likely that they will enhance OC storage over time. However, in our study OC stocks decreased with increasing marine influence. In this low-productivity region with soil C storage is a slow process (Meeder et al. 2017). However, we did find some evidence that mangroves may help to increase OC storage by identifying a near-significant interaction of mangroves with distance to coast $(P=0.06)$. We suggest that any positive impact of mangrove vegetation is partially confounded by association with marine influence on soil characteristics.

Wetlands closer to the coast had lower soil OC stocks despite higher mangrove cover. Saltwater intrusion is negatively related to sawgrass productivity and survival (Ewel et al. 2006; Macek and Rejmankova 2007; Troxler et al. 2014). The Southeast Saline Everglades have been subjected to some of the most extreme saltwater intrusion in the greater Everglades due to road and canal development, that isolated the region from freshwater flow (Sklar et al. 2005). Over the past half century, saltwater intrusion has 
driven the interior expansion of a zone of sparse vegetation (the "white zone,") into what was previously denser-canopied freshwater marsh (Egler 1952; Ross et al. 2000). Similarly, along the ecotone, sawgrass marsh has been converted to a patchwork of open water ponds, through a poorly-understood process called "peat collapse". In much of the Southeast Saline Everglades, the loss of freshwater and brackish vegetation and the white zone expansion has driven soil OC loss, for decades due to saltwater intrusion that was exacerbated.

Our results indicate that saltwater intrusion is likely to reduce soil OC stocks across the coastal wetlands Everglades, but that mangrove expansion and colonization could mitigate some OC loss. Although our study suggests mangroves may enhance carbon storage across the landscape by increasing root biomass and productivity, mangroves are becoming established in a region that has already undergone soil OC loss. Our results indicate that mangroves enhance OC inputs, but soil development and OC accretion is slow in low-productivity, severely P-limited wetlands like the Southeast Saline Everglades (Meeder et al. 2017), and the recovery of lost soil OC has not yet occurred. The storage of organic matter is a slow process governed by the balance between OC inputs and breakdown (Baustian et al. 2012). Additionally, soil elevation is governed by accumulation of organic and inorganic materials (Morris et al. 2002, Nyman et al. 2006; McKee 2011), but in sediment-poor wetlands $>1 \mathrm{~km}$ from the coast, like the Southeast Everglades, elevation gains are largely determined by organic matter accumulation particularly from roots (Hatton et al. 1983; Nyman et al. 1993; 2006; Turner et al. 2001; Delaune and Pezeshki 2002). 
In P-limited oligotrophic estuaries, like the Florida Everglades, saltwater intrusion provides a nutrient subsidy (potentially stimulating productivity), but also increase the stress of salinity, with uncertain overall impacts on plant productivity and biomass accumulation (Childers et al. 2006). The impacts of saltwater intrusion on belowground C storage are uncertain. Salinity often decreases root productivity, and nutrient subsidies often increase aboveground biomass but have uncertain impacts on root productivity. Nutrient addition can increase above and belowground productivity in some coastal ecosystems (McKee et al. 2007), but root productivity can be high in low-nutrient peatlands (Castaneda-Moya et al. 2011) compared to carbonate-rich wetlands. Although saltwater intrusion is likely to drive OC loss from many coastal wetlands, we lack an understanding of how saltwater intrusion, vegetation shifts, soil characteristics and nutrient availability interact across coastal wetland landscapes.

Coastal wetlands store more OC per area than other ecosystems (Chmura et al. 2003; Bouillon 2011; McLeod et al. 2011), providing a globally important feedback to climate change and the storage of OC and belowground biomass in soils often drives wetland surface elevation change (Nyman et al. 1993, 2006; Turner et al. 2000; McKee et al. 2007; Neubauer 2008). Many coastal wetlands have increase their surface elevation to persevere through gradual rates of SLR for thousands of years (Woodroffe et al. 1990; McKee et al. 2007). As SLR accelerates, there is concern that large portions of coastal wetlands may be lost to submergence in the coming century (Wanless et al. 2004; Cooper et al. 2008; Morris et al. 2016). Our data suggests that OC loss from coastal wetlands may exacerbate the submergence of wetlands. However biophysical feedbacks such as mangrove encroachment that enhance vertical elevation gain may increase resilience and 
preserve most wetland area (Kirwan et al. 2016). Our results suggest that soil OC loss is likely as saltwater intrudes into freshwater and brackish wetlands, but that the inland encroachment of mangroves may increase coastal wetland $\mathrm{C}$ storage and increase resilience to SLR. The fate of many coastal wetlands rests on the interaction of biophysical changes associated with water and soil chemistry and the survival or replacement of wetland vegetation.

\section{ACKNOWLEDGMENTS}

This research was funded in part by an Institutional Grant (\#\#\#) from Everglades National Park. Sean Charles was supported by a Dissertation Year Fellowship from Florida International University. Patricia Leroy, Suzanna Stofella and Jesus Blanco provided laboratory and field assistance. This is publication is contribution number XXXX for the Southeast Environmental Research Center.

\section{LITERATURE CITED}

Bernal B, McKinley DC, Hungate BA, White PM, Mozdzer TJ, Megonigal JP. 2016. Limits to soil carbon stability; Deep, ancient soil carbon decomposition stimulated by new labile organic inputs. Soil Biology and Biochemistry 98:85-94.

Bianchi TS, Allison MA, Zhao J, Li X, Comeaux RS, Feagin RA, Kulawardhana RW. 2013. Historical reconstruction of mangrove expansion in the Gulf of Mexico: Linking climate change with carbon sequestration. Estuarine, Coastal and Shelf Science 119:7-16.

Cahoon, D. R., P. Hensel, J. Rybczyk, K. L. McKee, C. E. Proffitt, and B. C. Perez. 2003. Mass tree mortality leads to mangrove peat collapse at Bay Islands, Honduras after Hurricane Mitch. Journal of Ecology 91:1093-1105. 
Chen, I. C., J. K. Hill, R. Ohlemuller, D. B. Roy, and C. D. Thomas. 2011. Rapid Range Shifts of Species Associated with High Levels of Climate Warming. Science 333:1024-1026.

Chmura, G. L., S. C. Anisfeld, D. R. Cahoon, and J. C. Lynch. 2003. Global carbon sequestration in tidal, saline wetland soils. Global Biogeochemical Cycles 17:12.

Deegan, L. A., D. S. Johnson, R. S. Warren, B. J. Peterson, J. W. Fleeger, S. Fagherazzi, and W. M. Wollheim. 2012. Coastal eutrophication as a driver of salt marsh loss. Nature 490:388-+.

Dessu, S. B., R. M. Price, T. G. Troller, and J. S. Kominoski. 2018. Effects of sea-level rise and freshwater management on local water levels and water quality in the Florida Coastal Everglades. Journal of Environmental Management 211:164- 176.

Doughty CL, Langley JA, Walker WS, Feller, IC, Schaub R, Champan SK. 2015. Mangrove range expansion rapidly increases coastal wetland carbón storage. Estuaries and Coasts 39:385-396.

D'Odorico P, He YF, Collins S, De Wekker SFJ, Engel V, and Fuentes JD. 2013. Vegetation-microclimate feedbacks in woodland-grassland ecotones. Global Ecology and Biogeography 22:364-379.

Elridge DJ, Bowker MA, Maestre FT, Roger E, Reynolds JF and Whitford WG. Impacts of shrub encroachment on ecosystem structure and functioning: towards a globalsynthesis. Ecology Letters 14:709-722.

Ewel KC, Twilley RR, and Ong JE. 1998. Different kinds of mangrove forests provide different goods and services. Global Ecology and Biogeography Letters 7:83-94.

Fagherazzi S, Carniello L, D’Alpaos L, and Defina A. 2006. Critical bifurcation of shallow microtidal landforms in tidal flats and salt marshes. Proceedings of the National Academy of Science 103:8337-8341.

Fierer N, Craine JM, McLauchlan K, and Schimel JP. 2005. Litter quality and the temperature sensitivity of decomposition. Ecology 86:320-326.

Flower, H., M. Rains, and C. Fitz. 2017a. Visioning the Future: Scenarios Modeling of the Florida Coastal Everglades. Environmental Management 60:989-1009. 
Flower, H., M. Rains, D. Lewis, J. Z. Zhang, and R. Price. 2017b. Saltwater intrusion as potential driver of phosphorus release from limestone bedrock in a coastal aquifer. Estuarine Coastal and Shelf Science 184:166-176.

Gill AM, and Tomlinson PB. 1977. Studies on the growth of red mangrove (Rhizophora mangle L.) 4. The adult root system. Biotropica 9:145-155.

Guo H, Weaver C, Charles S, Whitt A, Dastidar S, D'Odorico P, Fuentes JD, Kominoski JS, Armitage AR, Pennings SC. 2017. Coastal regime shifts: Rapid responses of coastal wetlands to changes in mangrove cover. Ecology 98: 762-77.

Haigh, I. D., T. Wahl, E. J. Rohling, R. M. Price, C. B. Pattiaratchi, F. M. Calafat, and S. Dangendorf. 2014. Timescales for detecting a significant acceleration in sea level rise. Nature Communications 5:11.

Herbert, E. R., P. Boon, A. J. Burgin, S. C. Neubauer, R. B. Franklin, M. Ardon, K. N. Hopfensperger, L. P. M. Lamers, and P. Gell. 2015. A global perspective on wetland salinization: ecological consequences of a growing threat to freshwater wetlands. Ecosphere 6:43.

Hurvich CM, and Tsai CL. 1989. Regression and time series model selection in small samples. Biometrika 76: 297-307.

Karam A. 1993. Chemical properties of organic soils. In: Carter MR, for Canadian Society of Soil Science, Eds. Soil sampling and methods of analysis. London: Lewis Publishers. Pp 459-471.

Kelleway, JJ, Saintilan N, Macreadie PI, Skilbeck CG, Zawadski A, and Ralph PJ. 2016. Seventy years of continuous encroachment substantially increases "blue carbon" capacity as mangroves replace intertidal salt marshes. Global Change Biology 22: 1097-1109.

Kelleway JJ, Cavanaugh K, Rogers K, Feller IC, Ens E, Doughty C, and Saintilan N. 2017.Review of the ecosystem service implications of mangrove encroachment into salt marshes. Global Change Biology 23: 3967-3983.

Kirwan, M. L., and J. P. Megonigal. 2013. Tidal wetland stability in the face of human impacts and sea-level rise. Nature 504:53-60.

Kirwan, M. L., S. Temmerman, E. E. Skeehan, G. R. Guntenspergen, and S. Fagherazzi. 2016. Overestimation of marsh vulnerability to sea level rise. Nature Climate Change 6:253-260. 
Knapp AK, Briggs JM, Collins S, Archer S, Bret-Harte M, Ewers BE, Peters DP, Young DR, Shaver GR, Pendall E and Cleary MB. 2008. Shrub encroachment in North American grasslands: Shifts in growth form dominance rapidly alters control of ecosystems carbon inputs. Global Change Biology 14:615-623.

Kominoski, J. S., J. J. F. Shah, C. Canhoto, D. G. Fischer, D. P. Giling, E. Gonzalez, N. A. Griffiths, A. Larranaga, C. J. LeRoy, M. M. Mineau, Y. R. McElarney, S. M. Shirley, C. M. Swan, and S. D. Tiegs. 2013. Forecasting functional implications of global changes in riparian plant communities. Frontiers in Ecology and the Environment 11:423-432.

Krauss KW, Doyle TW, Twilley RR, Smith TJ III, Whelan KRT, and Sullivan JK. 2005. Woody debris in mangrove forests of South Florida. Biotropica 37:9-15.

Krauss K, McKee KL, Lovelock CE, Cahoon DR, Saintilan N, Reef R, and Chen L. 2013. How mangrove forests adjust to rising sea level. New Phytologist 202:1934.

Kuzyakov Y. 2010. Priming effects: Interactions between living and dead organic matter. Soil biology and biochemistry 42:1363-1371.

Lefcheck, J. S. 2016. PIECEWISESEM: Piecewise structural equation modelling in R for ecology, evolution, and systematics. Methods in Ecology and Evolution 7:573579.

McKee, K. L., D. R. Cahoon, and I. C. Feller. 2007. Caribbean mangroves adjust to rising sea level through biotic controls on change in soil elevation. Global Ecology and Biogeography 16:545-556.

McKee KL. 2011. Biophysical controls on accretion and elevation change in Caribbean mangrove ecosystems. Estuarine, Coastal and Shelf Science 91:475-483.

McLeod, E., G. L. Chmura, S. Bouillon, R. Salm, M. Bjork, C. M. Duarte, C. E. Lovelock, W. H. Schlesinger, and B. R. Silliman. 2011. A blueprint for blue carbon: toward an improved understanding of the role of vegetated coastal habitats in sequestering CO2. Frontiers in Ecology and the Environment 9:552560 .

McVoy, C., P. W. Said, J. Obeysekera, J. A. VanArman, and T. W. Drescher. 2011. Landscapes and hydrology of the predrainage Everglades. University Press of Florida, Gainesville, Florida. 
Middleton BA, and McKee KL. 2001. Degradation of mangrove tissues and implications for peat formation in Belizean island forests. Ecology 89:818-828.

Morris JT, Sundareshwar PV, Nietch CT, Kjerfve B, and Cahoon DR. 2002. Responses of coastal wetlands to rising sea level. Ecology 83:2869-2877.

Morris JT, Barber DC, Callaway JC, Chambers R, Hagen SC, Hopkinson CS, Johnson BJ, Megonigal P, Neubauer SC, Troxler T, and Wigand C. 2016. Contributions of organic and inorganic matter to sediment volume and accretion in tidal wetlands at steady state. Earth's Future 4:110-121.

Nyman JA, Walters RJ, Delaune RD, and Patrick WH. 2006. Marsh vertical accretion via vegetative growth. Estuarine, Coastal and Shelf Science 69: 370-380.

Osland MJ, Spivak AC, Nestlerode JA, Lessmann JM, Almario AE, Heitmuller PT, Russell MJ, Krauss KW, Alvarez F, Dantin DD, Harvey JE, From AS, Cormier N, and Stagg CL. 2012. Ecosystem development after mangrove wetland creation plant-soil change across a 20-year chronosequence. Ecosystems 15:848-866.

Osland MJ, Enwright N, Day RH, and Doyle TW. 2013. Winter climate change and coastal wetland foundation species: salt marshes vs. mangrove forests in the southeastern United States. Global Change Biology 19:1482-1494.

Osland MJ, Enwright NM, Day RH, Gabler CA, Stagg CL, and Grace JB. 2016. Beyond just sea-level rise: considering macroclimatic drivers within coastal wetland vulnerability assessments to climate change. Global Change Biology 22:1-11.

Osland MJ, Feher LC, Griffith KT, Cavanaugh KC, Enwright NM, Day RH, Stagg CL, Krauss KW, Howard RJ, Grace JB, and Rogers K. 2017. Climatic controls on the global distribution, abundance and species richness of mangrove forests. Ecological Monographs 87:341-359.

Nerem, R. S., B. D. Beckley, J. T. Fasullo, B. D. Hamlington, D. Masters, and G. T. Mitchum. 2018. Climate-change-driven accelerated sea-level rise detected in the altimeter era. Proceedings of the National Academy of Sciences of the United States of America 115:2022-2025.

Neubauer, S. C. 2008. Contributions of mineral and organic components to tidal freshwater marsh accretion. Estuarine Coastal and Shelf Science 78:78-88.

Neubauer, S. C., and J. P. Megonigal. 2015. Moving Beyond Global Warming Potentials to Quantify the Climatic Role of Ecosystems. Ecosystems 18:1000-1013. 
Nyman, J. A., R. D. Delaune, H. H. Roberts, and W. H. Patrick. 1993. Relationship between vegetation and soil formation in a rapidly submerging coastal marsh. Marine Ecology Progress Series 96:269-279.

Nyman, J. A., R. J. Walters, R. D. Delaune, and W. H. Patrick. 2006. Marsh vertical accretion via vegetative growth. Estuarine Coastal and Shelf Science 69:370-380.

Price, R. M., M. R. Savabi, J. L. Jolicoeur, and S. Roy. 2010. Adsorption and desorption of phosphate on limestone in experiments simulating seawater intrusion. Applied Geochemistry 25:1085-1091.

Ross, M. S., J. F. Meeder, J. P. Sah, P. L. Ruiz, and G. J. Telesnicki. 2000. The Southeast Saline Everglades revisited: 50 years of coastal vegetation change. Journal of Vegetation Science 11:101-112.

Sandoval, E., R. M. Price, D. Whitman, and A. M. Melesse. 2016. Long-term (11 years) study of water balance, flushing times and water chemistry of a coastal wetland undergoing restoration, Everglades, Florida, USA. Catena 144:74-83.

Saintilan N, Wilson NC, Rogers K, Rajkaran A, and Krauss KW. 2014. Mangrove expansion and salt marsh decline at mangrove poleward limits. Global Change Biology 20:147-157.

Sklar, F. H., M. J. Chimney, S. Newman, P. McCormick, D. Gawlik, S. L. Miao, C. McVoy, W. Said, J. Newman, C. Coronado, G. Crozier, M. Korvela, and K. Rutchey. 2005. The ecological-societal underpinnings of Everglades restoration. Frontiers in Ecology and the Environment 3:161-169.

Smith TJ III, Foster A, Tiling-Range G, and Jones JW. 2013. Dynamics of mangroveMarsh ecotones in subtropical coastal wetlands: fire, sea-level rise, and water levels. Fire Ecology 9:66-77.

Titus, J. G., and C. Richman. 2001. Maps of lands vulnerable to sea level rise: modeled elevations along the US Atlantic and Gulf coasts. Climate Research 18:205-228.

Trenberth, K. E., A. G. Dai, G. van der Schrier, P. D. Jones, J. Barichivich, K. R. Briffa, and J. Sheffield. 2014. Global warming and changes in drought. Nature Climate Change 4:17-22. 
Twilley RR, Lugo AE, and Patterson-Zucca C. 1986. Litter Production and Turnover in basin mangrove forests in southwest Florida. Ecology 67:670-683.

Van Auken OW. 2000. Shrub invasions of North American semiarid grasslands. Annual Review of Ecology and Systematics 31:197-215.

Vogt KA, Vogt DJ, and Bloomfield J. 1998. Analysis of some direct and indirect methods for estimating root biomass and production of forests at an ecosystem level. Plant Soil 200: 71-89.

Wdowinski, S., R. Bray, B. P. Kirtman, and Z. H. Wu. 2016. Increasing flooding hazard in coastal communities due to rising sea level: Case study of Miami Beach, Florida. Ocean \& Coastal Management 126:1-8.

White, E., and D. Kaplan. 2017a. Restore or retreat? saltwater intrusion and water management in coastal wetlands. Ecosystem Health and Sustainability 3.

Woodroffe, C. D. 1990. The impact of sea-level rise on mangrove shorlines. Progress in Physical Geography 14:483-520.

Yando ES, Osland MJ, Willis JM, Day RH, Krauss KW, and Hester MW. 2016. Salt marsh-mangrove ecotones: Using structural gradients to investigate the effects of woody plant encroachment on plant-soil interactions and ecosystem carbon pools. Journal of Ecology 104: 1020-1031. 
Table 1. Linear mixed-effects models and model weights of fixed effects from significant relationships between distance to coast and soil nutrient characteristics $(\% \mathrm{~N}, \% \mathrm{P}, \mathrm{C}: \mathrm{N}, \mathrm{N}: \mathrm{P}$ ratios) and vegetation characteristics (mangrove cover, marsh cover and total cover). And distance to coast, soil nutrient characteristics and vegetation characteristics on soil carbon stocks and fluxes.

Response variables and fixed predictors were standardized with the equation variable $=(x-\operatorname{mean}(x)) / \operatorname{stdev}(x)$ to ensure that variables were on similar scales and to meet the assumptions of normality. Vegetation characteristics were measured in $1 \mathrm{~m}^{2}$ plots, while soil characteristics were measured with one soil core in the center of each site. Carbon stocks and fluxes were measured in three plots per site. We list only the most parsimonious models for each response, as determined by lowest AICc, and any models whose AICc is within 2 points of the top model (Burnham and Anderson 2002).

\begin{tabular}{llccccc}
\hline $\begin{array}{l}\text { Response } \\
\text { variable }\end{array}$ & Models & $\begin{array}{c}\text { Log } \\
\text { likelihood }\end{array}$ & AICc & $P$ - value & $\begin{array}{c}\text { Conditional } \\
\mathrm{R}^{2}\end{array}$ & Equation \\
\hline Influence of distance from coast & & & & \\
\hline $\begin{array}{l}\text { Mangrove } \\
\text { cover }\end{array}$ & $\begin{array}{l}\text { Distance } \\
\text { to coast }\end{array}$ & -272.91 & 556.89 & 0.049 & 0.19 & $\mathrm{y}=-4.3$ (Distance) +35.16 \\
$\% \mathrm{~N}$ & $\begin{array}{l}\text { Distance } \\
\text { to coast }\end{array}$ & 47.69 & -79.4 & 0.01 & 0.35 & $\mathrm{y}=0.007($ Distance) +0.02 \\
$\mathrm{N}: \mathrm{P}$ & $\begin{array}{l}\text { Distance } \\
\text { to coast }\end{array}$ & -51.65 & 117.92 & 0.03 & 0.55 & $\mathrm{y}=1.846($ Distance) +0.023 \\
$\mathrm{C}: \mathrm{N} \quad \begin{array}{l}\text { Distance } \\
\text { to coast }\end{array}$ & -69.71 & 154.03 & 0.01 & 0.34 & $\mathrm{y}=-6.55$ (Distance) +64.63 \\
\hline Organic Matter Fluxes & & & & & \\
\hline
\end{tabular}




\begin{tabular}{|c|c|c|c|c|c|c|}
\hline $\begin{array}{l}\text { Root } \\
\text { productivity } \\
\left(\mathrm{g} \mathrm{OC} \mathrm{m}^{-2} \mathrm{y}^{-}\right. \\
\text {1) }\end{array}$ & $\begin{array}{l}\text { Mangrove } \\
\text { cover }\end{array}$ & -42.36 & 96.95 & 0.001 & 0.3 & $\mathrm{y}=0.55($ Mangrove cover $)$ \\
\hline $\begin{array}{l}\text { Root } \\
\text { productivity } \\
\text { (g OC m }{ }^{-2} \mathrm{y}^{-} \\
{ }^{1} \text { ) }\end{array}$ & $\begin{array}{l}\text { Mangrove } \\
\text { cover }+ \\
\text { N:P }\end{array}$ & -41.21 & 97.66 & $\begin{array}{c}\text { Mancover } \\
=0.0009 \\
\mathrm{NP}= \\
0.04\end{array}$ & 0.34 & $\begin{array}{l}y=0.53(\text { Mangrove cover })- \\
0.31(N: P)-0.004\end{array}$ \\
\hline $\begin{array}{l}\text { Wood } \\
\text { breakdown }(k \\
\left.\mathrm{dd}^{-1}\right) 0-15 \\
\mathrm{~cm}\end{array}$ & $\mathrm{C}: \mathrm{N}$ & -33.91 & 80.36 & 0.02 & 0.66 & $y=0.42(C: N)-0.1$ \\
\hline $\begin{array}{l}\text { Wood } \\
\text { breakdown }(k \\
\left.\mathrm{dd}^{-1}\right) \quad 15-30 \\
\mathrm{~cm}\end{array}$ & $\mathrm{C}: \mathrm{N}$ & -19.69 & 89.62 & 0.03 & 0.36 & $y=0.22(C: N)-0.25$ \\
\hline $\begin{array}{l}\text { Cellulose } \\
\text { breakdown }(k \\
\left.\mathrm{dd}^{-1}\right) 15-30 \\
\mathrm{~cm}\end{array}$ & $\mathrm{C}: \mathrm{N}$ & -35.84 & 84.4 & 0.004 & 0.36 & $y=0.54(C: N)-0.003$ \\
\hline \multicolumn{7}{|c|}{ Organic Carbon Stocks } \\
\hline $\begin{array}{l}\text { Root biomass } \\
\left(\mathrm{g} \mathrm{OC} \mathrm{m}^{-2}\right) 0- \\
30 \mathrm{~cm}\end{array}$ & $\begin{array}{l}\text { Mangrove } \\
\text { cover }\end{array}$ & -77.16 & 165.59 & $<0.001$ & 0.34 & $\begin{array}{l}y=0.58(\text { Mangrove cover })+ \\
0.00\end{array}$ \\
\hline $\begin{array}{l}\text { Soil \%OC }(0- \\
15 \mathrm{~cm})\end{array}$ & Distance & -63.51 & 138.09 & $<0.001$ & 0.63 & $y=0.66($ Distance $)+0.03$ \\
\hline
\end{tabular}


Figure 1. Conceptual model predicting the influence of proximity to coast on ecosystem properties and soil carbon storage. The size of plusses and minuses indicate the hypothesized magnitude of each ecosystem link. We predicted that saltwater intrusion from sea level rise and water management will drive saltwater influence further inland, thus influencing carbon stocks and fluxes on different time scales.

Figure 2. Site map. We chose 19 sites that spanned the marsh-mangrove ecotone in the Southeast Saline Everglades in Florida, USA. Sites were chosen based on location within and adjacent to the marsh-mangrove ecotone, and because previous data (Ross et al. 2000) on vegetation shows that this region has experienced large change in vegetation type and cover.

Figure 3. Proximity to the coast and vegetation and soil characteristics. We compared distance to coast (the location of each measurement to the closest open coastline) to vegetation and soil characteristics using generalized mixed effects models. For each measurement we accounted for spatial autocorrelation by creating a random effect of location (transect/region). Solid lines represent best fit from linear mixed effects models $(P<0.05)$, and dashed lines are 95 percent confidence intervals. (a) Mangrove cover measured within $1 \mathrm{~m}^{2}$ vegetation plots that we utilized for root biomass and OC measurements. (b) Percent nitrogen $(\% \mathrm{P})$ in the surface soil $(0-15 \mathrm{~cm})$ taken from the center of each site $(n=19)$. (c) Soil molar carbon to nitrogen ratios $(C: N)$ in the surface soil $(0-15 \mathrm{~cm})$ taken from the center of each site. (d) Soil molar nitrogen to phosphorus ratios in the surface soil $(0-15 \mathrm{~cm})$ taken from the center of each site.

Figure 4. Soil carbon fluxes. We used generalized mixed effects models to identify the drivers of root productivity and organic matter breakdown. For each measurement we accounted for spatial autocorrelation by creating a random effect of location (transect/region). Solid lines represent best fit from linear mixed effects models $(P<$ 0.05), and dashed lines are 95 percent confidence intervals. (a) The most parsimonious model to describe root ingrowth was a linear model with mangrove cover as the sole 
driver. Root productivity was measure as ingrowth $(0-30 \mathrm{~cm})$ and normalized as grams of OC per year. (b) Wood standard substrates breakdown was measured in the surface soil $(10 \mathrm{~cm})$ and breakdown rates were normalized per degree day to represent $k \mathrm{dd}^{-1}$.

Figure 5. Soil carbon stocks. We used generalized mixed effects models to identify the drivers of root productivity and organic matter breakdown. For each measurement we accounted for spatial autocorrelation by creating a random effect of location (transect/region). Solid lines represent best fit from linear mixed effects models $(P<$ 0.05 ), and dashed lines are 95 percent confidence intervals. (a) The best model to predict root biomass solely included mangrove cover. We measured live roots from root cores (30 cm deep) taken from the center of $1 \mathrm{~m}^{2}$ vegetation plots. Root biomass is expressed as OC content. (b) The model that best predicted surface soil OC $(0-15 \mathrm{~cm})$ was distance from coast. Soil cores were taken taken adjacent to root cores and we measured distance from the location of each core location to the nearest open coastline.

Figure 6. We used a piecewise structural equation models (Lefcheck 2015) to measure linkages between proximity to the coast, vegetation and soil chemical characteristics, soil carbon fluxes (root productivity and organic matter breakdown rates) and soil carbon stocks (root biomass and soil organic carbon content). The corresponding model list is composed of linear mixed effects models (individual statistical output described in table 1), run with the R package "lme4". We ran the model in R with the package "piecewiseSEM." We identified the most parsimonious overall model and removed linkages to minimize AICc. We show only significant correlations $(P<0.05)$ as standardized path coefficients. We display all soil characteristics, stocks and fluxes of OC from our original conceptual figure (figure 1) despite the lack of significant linkages between them. 


\section{Figure 1.}

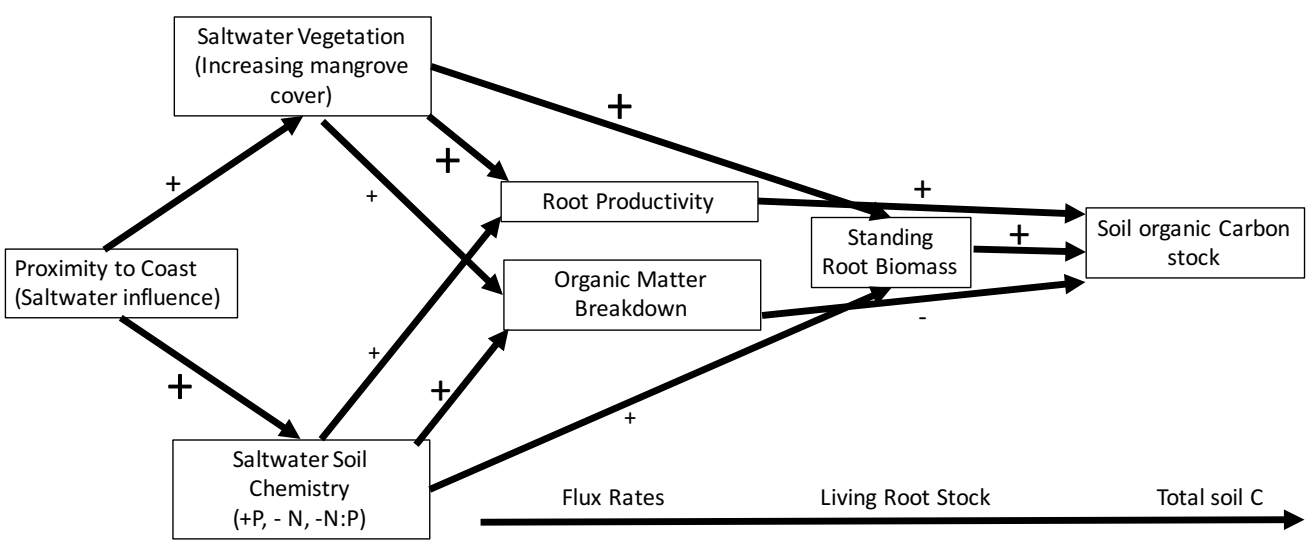

Soil Carbon response to saltwater intrusion through time 


\section{Figure 2.}

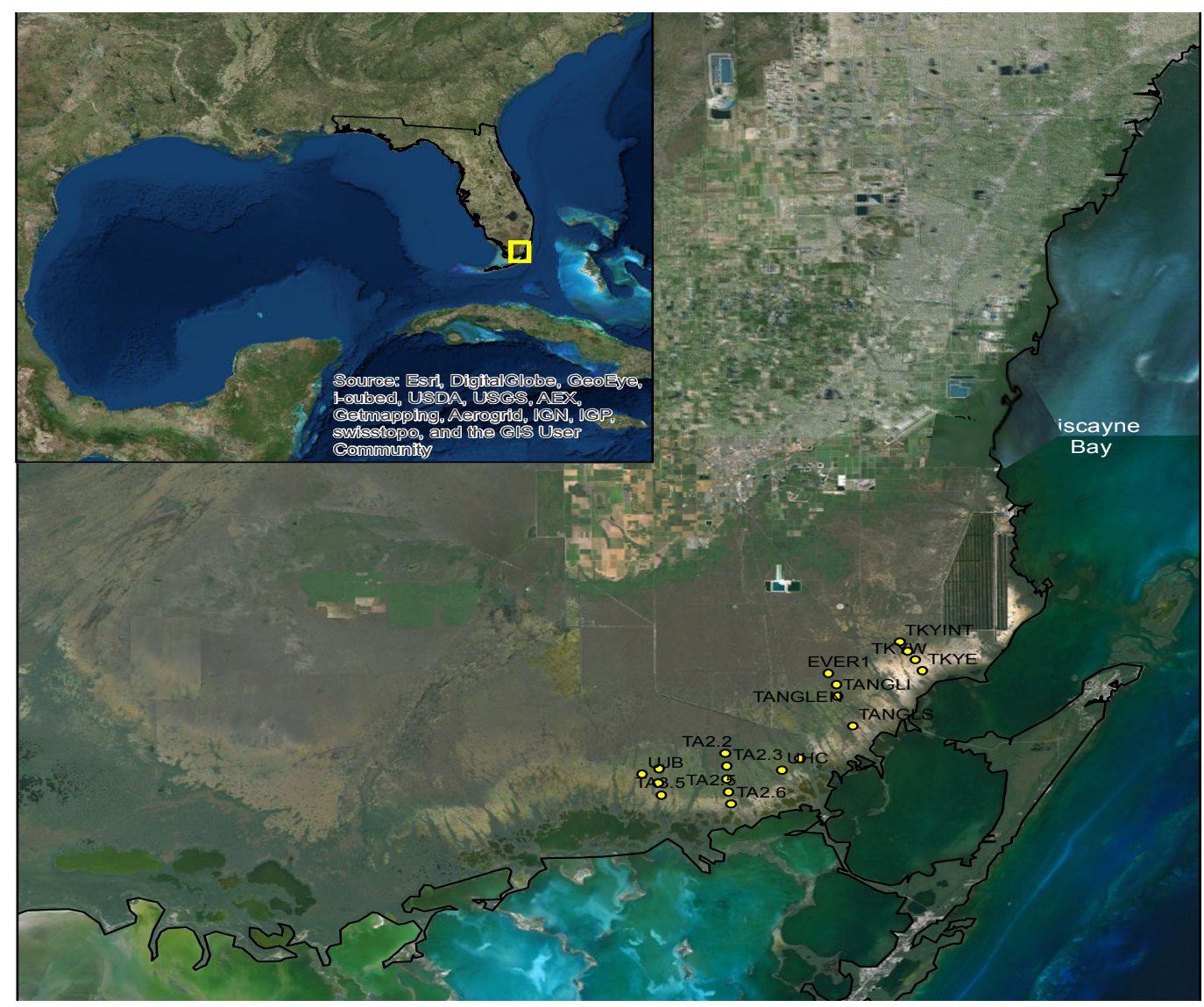


Figure 3.

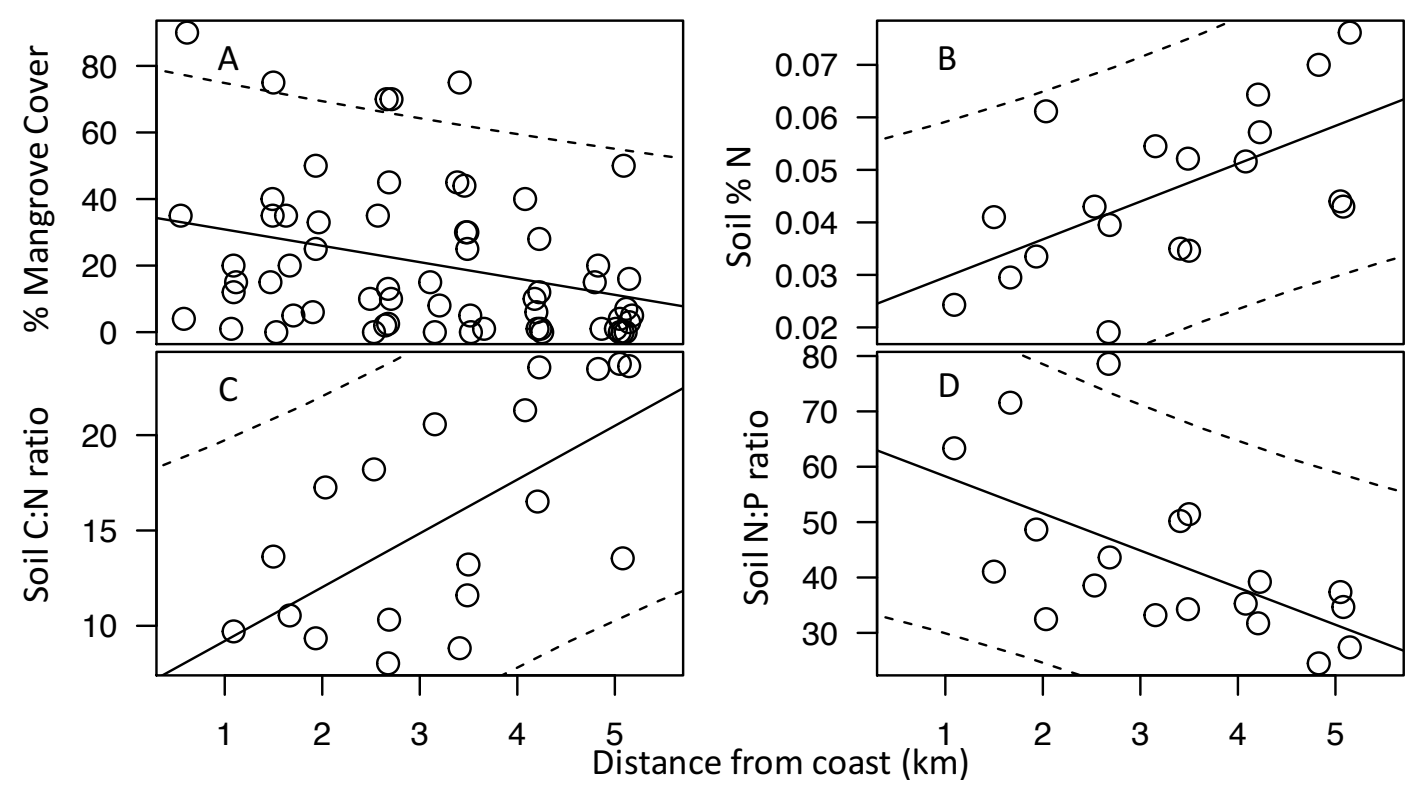


Figure 4
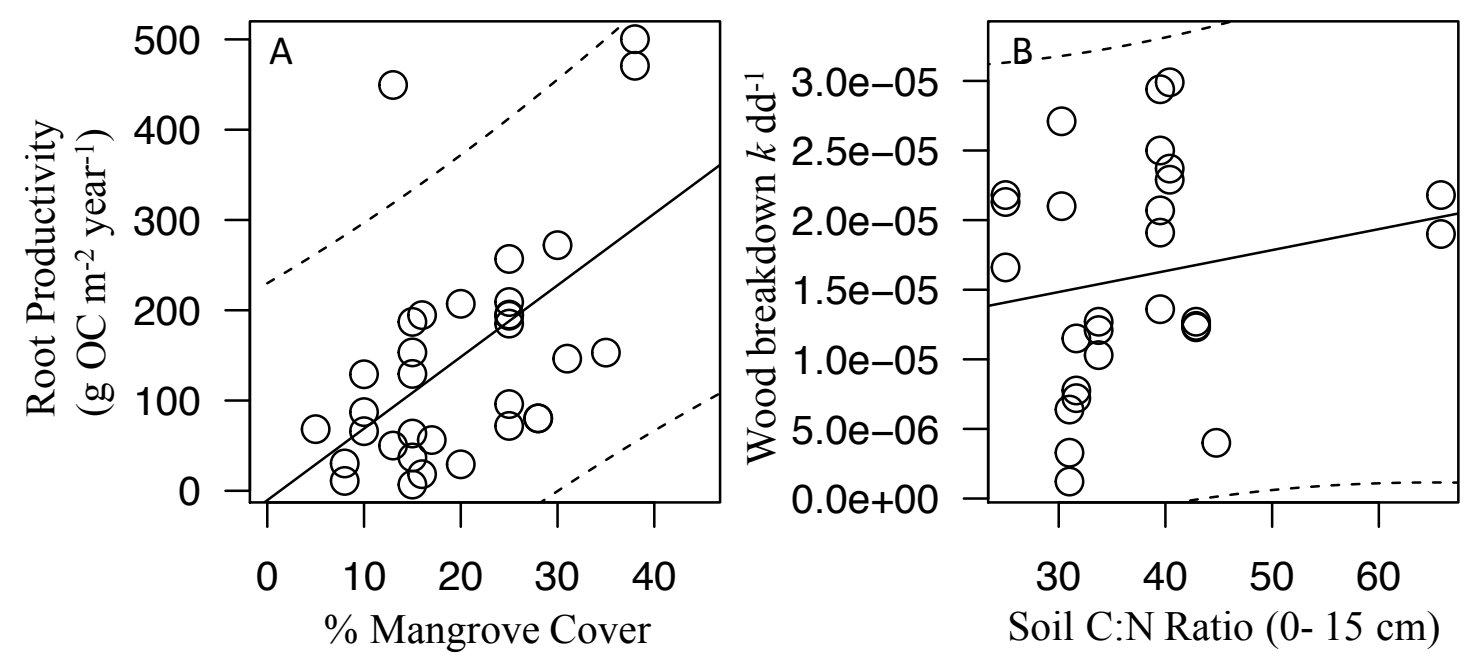
Figure 5
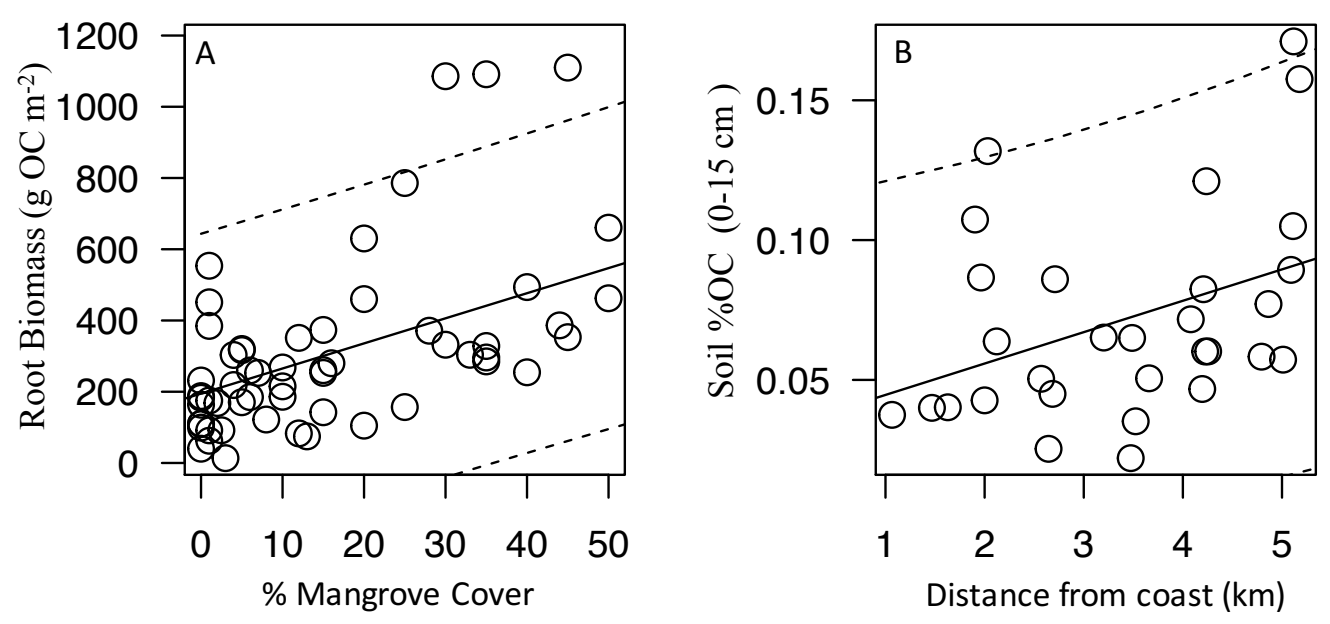
Figure 6.

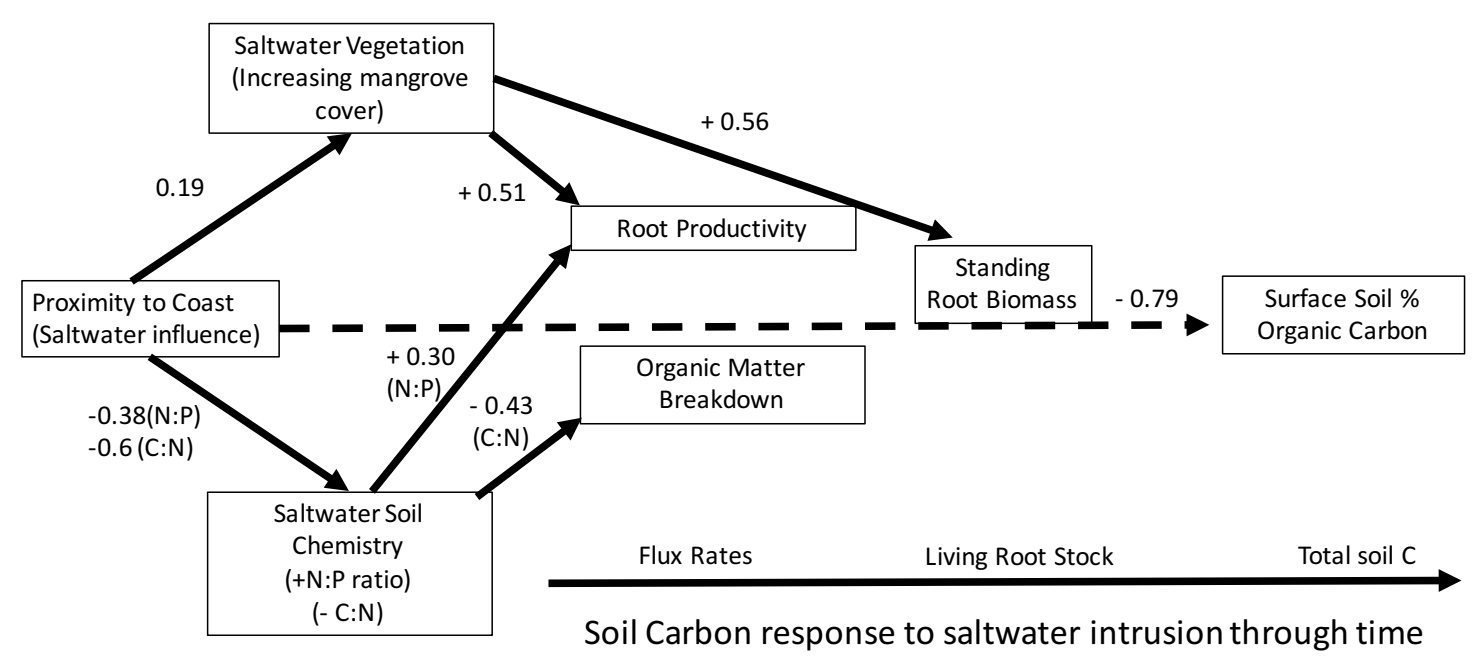




\section{CHAPTER IV}

QUANTIFYING CHANGES IN ORGANIC CARBON STORAGE WITH VARIATION IN PLANT IDENTITY AND AGE ALONG A COASTAL MARSH-MANGROVE GRADIENT 


\title{
Quantifying changes in organic carbon storage with variation in plant identity and age along coastal marsh-mangrove gradients
}

Sean P. Charles ${ }^{1}$, John S. Kominoski ${ }^{1}$, Donny Smoak ${ }^{2}$

${ }^{1}$ Department of Biological Sciences and Southeast Environmental Research Center, Florida International University, Miami, FL 33199 USA

${ }^{2}$ Department of Environmental Science, Policy and Geography, University of South Florida. St. Petersburg, Florida 33701.

\begin{abstract}
Saltwater intrusion is causing vegetation shifts across coastal wetland landscapes, with uncertain implications for ecosystem function. In tropical and subtropical environments saltwater intrusion drives shifts from freshwater and brackish marshes to woody mangrove vegetation. Coastal wetlands are among the most effective ecosystem carbon sinks, yet we lack a clear understanding of how saltwater intrusion into marsh communities and mangrove encroachment and development through time affect organic OC stocks and fluxes. We created a vegetation gradient across the marsh-mangrove ecotone, including low salinity "brackish" marshes (Spartina Bakeri and Cladium jamaicense), higher salinity "saltmarsh" (Juncus romerianus and Distichlis spicata) and a chronosequence of five age classes from mangroves established $<10$ to 75-88 years ago. Above and belowground biomass was similar between marsh types, but mangrove establishment increased aboveground biomass 10x after less than 10 years and increased aboveground biomass 30x and belowground biomass $2 \mathrm{x}$ in mangroves established $>20$ years ago, but no difference in biomass in mangroves $>20->88$ years since
\end{abstract}


establishment. Percent soil organic carbon (OC) was 4x higher in brackish marsh than saltmarsh, indicating that saltwater intrusion decreased soil OC stocks. However, mangrove encroachment drove recovery of soil OC stocks within 20 years and continued to develop through time, eventually containing $10 \mathrm{x}$ more OC in $75-88$ year old mangroves than saltmarsh. Mangrove development increased soil OC beginning in the surface soil and increasing in depth through time. Breakdown rates $(k)$ of ecosystemspecific leaf litter were slower in 75-88 year-old mangroves than saltmarshes and mangroves $<30$ years old. In the surface soil, roots broke down faster in mangroves between 10 and 75 years old than marsh or older mangroves $>75$ years old, while in deeper soil all mangroves $>10$ years old had higher breakdown rates than marsh. Surface accretion was higher in mangroves $>10$ years old than in marshes. Similarly, root productivity was higher in mangroves $20-75$ years old, but mangroves $<10$ and $>75$ years old were similar to marsh. Our study shows that as freshwater marsh vegetation is replaced by brackish marsh, ecosystem carbon storage decreases particularly in soil OC, but as mangroves encroach and develop through time, wetland ecosystems rapidly surpass biomass OC stocks and steadily enhance OC storage in the soil, providing a negative feedback to climate change and mitigating vulnerability to sea level rise.

Keywords: Mangrove encroachment, saltwater intrusion, carbon storage, coastal wetland vulnerability.

\section{INTRODUCTION}

Global changes are causing major shifts in plant communities worldwide (Chen et al. 2011). These transitions may have profound effects on a number of locally and 
globally important biogeochemical cycles. Accelerating sea level rise (SLR) is driving widespread saltwater intrusion and vegetation shifts in coastal wetlands (Herbert et al. 2015) with largely unclear functional implications. In particular, shifts between plant communities with drastically different traits are likely to alter ecosystem function (Kominoski et al. 2013; Saintillan et al. 2014; Guo et al. 2017). The encroachment of trees and shrubs into ecosystems dominated by herbaceous vegetation is occurring in many ecosystems, causing an obvious change in vegetation structure and often altering ecosystem function (Knapp et al. 2008; Guo et al. 2017). In this manuscript we quantify the effects of saltwater intrusion and vegetation change on organic carbon (OC) storage in coastal wetlands of the greater Florida Everglades.

Coastal wetlands are extremely valuable ecosystems, providing ecosystem services essential to the environment and society (Costanza et al. 2014; Barbieri et al. 2011). Coastal wetlands sequester $\mathrm{CO}_{2}$ from the atmosphere and store it as organic carbon (OC) in plant biomass and soils more effectively than other ecosystem types (Chmura et al. 2003; McLeod et al. 2011). Wetlands increase their elevation through accumulating soil OC and inorganic sediment (Morris et al. 2016) allowing many wetlands to keep pace with sea level rise (SLR for centuries to millennia (Woodroffe et a 1. 1990; McKee et al. 2007). The storage of OC provides a valuable negative feedback to climate change and the storage of OC belowground often drives wetland surface elevation change (Nyman et al. 2006; McKee et al. 2007). As SLR accelerates, wetlands are increasingly vulnerable to submergence and much of the uncertainty about wetland fate is based on plant-soil feedbacks to OC storage as environmental conditions are impacted by climate change (Kirwan and Megonigal 2013; Morris et al. 2016). 
Saltwater intrusion often disturbs plant communities (Pezeshki et al. 1987; McKee and Mendelsohn 1987; Krauss et al. 2012; Noe et al. 2013), reduces productivity (Neubauer 2013) and increases organic matter decomposition through sulfate reduction (Weston et al. 2011 Neubauer 2013; Chambers et al. 2013). Saltwater intrusion can cause reductions in OC storage through disturbance to vegetation communities, which reduces root biomass or productivity, and by destabilizing stored OC in soils. Saltwater intrusion can reduce plant productivity (Kraus et al. 2009; Neubauer 2008; Charles et al. in prep), starving soils of OC inputs necessary to facilitate OC storage and elevation gain (Kirwan and Megonigal 2013). Alternatively, saltwater intrusion can cause rapid root mortality, which reduces soil volume and destabilizes soils, causing rapid soil OC and elevation loss (Delaune et al. 1994; Charles et al. in prep). Saltwater intrusion can also accelerate decomposition rates by providing limiting nutrients or oxidizing soil (Weston et al. 2011; Neubauer et al. 2013; Chambers et al. 2014).

Plant regime shifts are likely to fundamentally alter OC storage and soil accretion in coastal wetlands. Plants can alter surface $\mathrm{C}$ storage through the production of differing quantities and qualities of organic matter (Twilley et al. 1986), altering capture and storage efficiency of autochthonous as well as allocthonous organic matter (Fagherazzi et al. 2006) and through alterations of microclimate that affect organic matter breakdown (Fierer et al. 2005; D'Odorico et al. 2013). Globally SLR has nearly tripled over the last century (Nerem et al. 2018). This has driven the migration of halophytes into terrestrial and freshwater ecosystems and in the tropics and subtropics saltwater intrusion often drives woody mangrove encroachment (Ross et al. 2000; Saintillan et al. 2014). In terrestrial ecosystems, woody encroachment generally leads to increased OC storage 
(Elridge et al. 2011). Although mangrove forests are known to store large levels of OC, so do herbaceous marshes, with no major difference in OC storage rates globally (Chmura et al. 2003). Furthermore, while some ecosystems show increased OC storage with salinity-driven mangrove encroachment (Santillan et al. 2014), in other ecosystems saltwater intrusion and mangrove encroachment can drive the loss of OC (Ross et al. 2000; Charles et al. in prep).

Plant roots are often the most significant driver of increased C storage in soils through the input of root biomass (McKee et al. 2007; Chmura 2011). Roots also play an essential role in priming breakdown of existing soil organic matter (SOM) through soil aeration and the production of labile exudates (Scholander et al. 1955; Kuzyakov 2010). Woody encroachment into short-statured herbaceous communities is occurring worldwide (Van Auken 2000; Frelich and Reich 2010), often altering albedo, temperature (D’Odorico et al. 2013), and basal C sources. Studies have identified the potential for mangroves to increase OC storage in coastal wetlands (Yando et al. 2017; Charles et al. in review), however whether vegetation regime shifts can overcome initial losses of soil OC, and over what time period represents an important knowledge gap essential for predicting OC storage and marsh stability during SLR.

Changes in OC stocks and fluxes associated with mangrove establishment are likely to develop as mangrove communities develop through time (Odum 1969; Osand et al. 2012), yet little is known about the OC sequestration of mangroves of different ages, as most studies focus on mature forests (Kristenen et al. 2008; Lunstrum and Chen 2014). Current knowledge is based on recovery of mangrove forests after disturbances (Ross et al. 2006) or the planting of mangroves for restoration or plantations, which often 
demonstrate OC storage as mangroves develop through time (Osland et al. 2012; Kairo et al. 2008; Tamooh et al. 2008).

Low-lying coastal wetland ecosystems, such as the Everglades are experiencing drastic changes because of upstream manipulation to freshwater flow and SLR (White and Kaplan 2017). Ten Thousand Islands National Wildlife Refuge (TTINWR), is located on the southwest coast of Florida, directly west of Everglades National Park and as in much of the greater Florida Everglades, Cladium jamaicense marshes dominate the fresher interior, whereas Rhizophora mangle, Laguncularia racemosa, and Avicennia germinans-dominated mangrove forest exist in saltier areas toward the coast, and the community types often overlap with brackish and saltmarsh in the ecotone (Egler 1952; Ross et al. 2000; Krauss et al. 2011). As sea level has increased and the inflow of freshwater has been reduced, saltwater intrusion has increased throughout the Everglades (Dessu et al. 2017), driving landscape changes and mangrove encroachment into herbaceous marshes (Ross et al. 2000; Smith et al. 2013). In particular, in TTINWR, between 1927 and 2005, mangroves expanded their range inland by 35\% at the expense of marsh (Krauss et al. 2011), with unknown impacts on OC stocks and fluxes.

Our objective was to quantify the effects of changes in coastal wetland vegetation composition and age on above and belowground standing stocks and fluxes of OC. We tested the following questions: 1) How do OC stocks, fluxes and surface accretion vary among wetlands dominated by brackish marsh, saltwater marsh and mangrove-dominated vegetation communities?; and 2) How does time since mangrove establishment affect soil C stocks, fluxes and OC accretion? We hypothesized that aboveground and belowground biomass would decrease with transition from brackish to saltmarsh but would increase as 
mangroves become increasingly developed over time, drastically increasing OC storage particularly in aboveground biomass. We also hypothesized that saltwater intrusion into brackish marshes and transition to saltmarsh communities would decrease OC storage in soils by increasing organic matter breakdown rates, but mangrove establishment and development would drive increased OC storage gradually through time (Figure 1).

\section{METHODS}

\section{Experimental setting}

We established a gradient of marsh to mangrove vegetation transition within Ten Thousand Islands National Wildlife Refuge (TTINWR) $\left(25^{\circ} 57^{\prime} \mathrm{N}, 81^{\circ} 32^{\prime} \mathrm{W}\right.$, Fig. 1). TTINWR is a coastal reserve in southwest Florida located just northwest of Everglades National Park. TTINWR vegetation represents a salinity gradient from brackish marsh wetlands, dominated by Cladium jamaicense (sawgrass) with some Spartina Bakeri, (sand cordgrass) in the reserve interior that transitions to more salinity tolerant vegetation communities, "saltmarshes," dominated by Juncus romerianus (black needlerush), and Distichlis spicata (saltgrass) and mixed mangrove assemblages (Rhizophora mangle, Laguncularia racemosa and Avicennia germinans respectively) dominate closer to the Gulf of Mexico.

Mangroves in TTINWR have encroached into graminoid marshes through expansion of their inland limits. We established five age classes of mangrove ecosystems based on analysis of historical aerial photography. Mangrove boundaries were established throughout TTINWR for three time periods (1927, 1940 and 2005) (Krauss et al. 2011; Figure 2) and we increased the number of age classes by establishing 
boundaries within our transects in 1985 and 1995. The 1927 mangrove boundaries were based on topographic sheets (detailed survey maps issued by the National Oceanographic and Atmospheric Administration, based on aerial photographs and subsequently georectified (Krauss et al. 2011). The 1940 mangrove boundary was based on the United States Geological Survey (Krauss et al. 2011). All remaining boundaries were based on aerial photography provided by the Collier County Appraiser's Office (Naples, Florida). Mangrove age classes were established based on preliminary visual classification based on color and texture (mangrove, non-mangrove), followed by subsequent ground trothing to distinguish between true mangroves (Rhizophora and other species with similar habitat preference. For example, to compare processes associated with marsh to mangrove transitions, we eliminated areas that were preliminarily classified as mangroves, which we determined were either currently buttonwood-dominated (Conocarpus erectus) tree islands, or which contained a high proportion of dead buttonwood wood or stumps, and were likely to have been buttonwood dominated in historical photographs.

We established three vegetation transects representing gradients in increasing saltwater intrusion and time since mangrove encroachment. We established replicates of two marsh ecosystem types and five age classes of mangrove ecosystems. The most interior sites were "brackish marshes" dominated by Cladium jamaicense and Spartina Bakeri with salinities ranging from 5-15 ppt followed by marshes with more salinity tolerant vegetation communities dominated by Juncus romerianus, and Distichlis spicata with salinities ranging from 15-23 ppt, which we have labeled "saltmarsh" (Howard et al. 2017). We then chose mangrove sites based on time since mangrove establishment to 
represent five age classes ( 0 - 10 years, $10-20$ years, $20-30$ years, $30-70$ years, and $75-88$ years) (Figure 2).

\section{Organic carbon standing stocks}

We calculated cover for all species within plots and calculated aboveground biomass for each woody species, and combined marsh species to calculate herbaceous biomass. We created 21 plots based on vegetation type on a stratified random basis within ecosystem types (Mueller Dumbois and Ellenberg 1974). We calculated aboveground biomass in nested plots for trees, saplings, seedlings and herbaceous vegetation. We measured tree biomass in $100 \mathrm{~m}^{2}$ plots based on diameter at breast height $(\mathrm{DBH})$ and height for all trees $>6 \mathrm{~cm} \mathrm{DBH}$. We calculated sapling aboveground biomass in $25 \mathrm{~m}^{2}$ plots with the same center point as our tree plot for woody plants $>0.7 \mathrm{~m}$ tall but $<6 \mathrm{~cm} \mathrm{DBH}$. Finally, we created three $1 \mathrm{~m}^{2}$ plots to measure herbaceous and mangrove seedling $(<0.7 \mathrm{~m}$ tall) biomass, (randomly assigned based based on distance from center and azimuth). We calculated woody biomass according to equations created by Osland et al. 2013. We quantified herbaceous and seedling biomass by harvesting all aboveground plant biomass in clip plots in the the northwest $0.25-\mathrm{m}^{2}$ corner of each $1 \mathrm{~m}^{2}$ plot (Mueller-Dumbois and Ellenberg 1974).

We measured belowground biomass based on two cores $(30 \mathrm{~cm}$ deep, $10 \mathrm{~cm}$ diameter) from each plot $(\mathrm{n}=42)$, taken $2 \mathrm{~m}$ North and $2 \mathrm{~m}$ South of the plot center. Roots were separated from sediment by rinsing through a 1-mm mesh sieve. Live roots were identified based on color, texture and pliability and collected for biomass measurements. Roots were dried at $45^{\circ} \mathrm{C}$ until mass stabilized and weighed for biomass. 
Roots (and all other samples) were then ground using an 8000-D ball mill (Spex SamplePrep, Metuchen, New Jersey, USA). We then measured ash-free dry mass $(\mathrm{AFDM})$ as loss on ignition in a muffle furnace at $550^{\circ} \mathrm{C}$ (Karam 1993) and converted to OC by dividing by 2 (Pribyl et al. 2010). We report root biomass as root OC $\mathrm{m}^{-2}$.

Soil C stocks were measured based on one (45 $\mathrm{cm}$ deep, $10 \mathrm{~cm}$ diameter), soil core from the center of each plot. We sectioned cores into $0-5,5-15,15-30$ and $30-45 \mathrm{~cm}$ sections ( $\mathrm{n}=21$ per depth). We dried soils at $45^{\circ} \mathrm{C}$ until mass stabilized for bulk density and calculated \%OC as described above.

\section{Organic carbon fluxes}

We measured breakdown rates of native leaf litter on the soil surface in each plot. We gathered senescent leaf litter from each ecosystem type, air-dried litter, and incubated $\sim 3 \mathrm{~g}$ on soil surfaces in each plot in 1-mm mesh litterbags. In each plot, we retrieved 4 replicate litterbags $(n=84)$ after $\sim 374$ days. Similarly, we measured the breakdown of native roots gathered from each ecosystem type with duplicate root breakdown bags inserted to represent two soil depths (0-15 $\mathrm{cm}$ and $15-30 \mathrm{~cm}$ deep) over 374 days ( $\mathrm{n}=$ 42 per depth).

We also measured breakdown rates of standard substrates of green and rooibos tea bags (Keuskamp et al. 2013) in the surface soil (10 cm deep) in each ecosystem type. Tea bags have been proven to be an easily standardized and accurate substrate to compare organic matter breakdown across ecosystem type, capturing inherent ecosystem differences in breakdown rate while eliminating the importance of species traits and microbial preference (Keuskamp et al. 2013). 
For all organic matter breakdown we returned all samples to the laboratory on ice, rinsed them of sediment, and calculated dry mass and AFDM as described above. We estimated breakdown rate, $k$, using a linear regression of the ln-transformed fraction of AFDM remaining vs. time (negative exponential model; sensu Benfield 2006). The specific model used is $M_{t}=M_{0} \bullet e^{-k t}$, where $M_{0}$ is the initial litter mass, $M_{t}$ is the litter mass on a given sampling day, $t$ is time (days of incubation).

We measured root productivity with the ingrowth core method, by inserting duplicate mesh bags filled with commercial peat moss (30 $\mathrm{cm}$ deep, $5 \mathrm{~cm}$ diameter) into the soil and retrieving them after 374 days (Vogt et al. 1998; McKee et al. 2007). We sieved cores in the same way as belowground biomass, but collected all roots (living and dead) to calculate the full yearly OC inputs associated with root productivity (McKee et al. 2007). Root productivity was standardized to represent one year and expressed as OC $\mathrm{m}^{-2} \mathrm{y}^{-1}$

Finally, I measured surface sediment accretion above one $0.5 \mathrm{~m}^{2}$ located adjacent to the center of each plot (Cahoon and Turner 1989). We measured depth accretion after 374 days and standardized to $\mathrm{mm}^{-1}$.

\section{RESULTS}

\section{Vegetation dynamics}

Brackish marshes were dominated by $C$. jamaicense (33\% cover) and S. bakeri (18\% cover). Saltmarshes were dominated by Juncus romerianus (52\% cover), with Distichilis spicata (13\%) and generally contained a low percentage of L. racemosa seedlings (1\% cover). L. racemosa dominated mangrove plots for the first 20 years, 
making up $>80 \%$ of all aboveground biomass, however after 20 years, $L$. racemose dropped to an average of $36 \%$ as $R$. Mangle become established. However, we found a trend of $R$. mangle becoming established and increasing biomass from $8 \%$ within 10 years to $<50 \%$ in 20-30 years. Finally, in 75-88 year old mangrove forests, $A$. germinans becomes established and all three mangrove species are equally represented, comprising 28-30\% of total biomass, while C. erectus contributes $13.5 \%$ (Table 1).

\section{Organic carbon standing stocks}

Aboveground biomass showed large differences among ecosystem types $(p<$ 0.001; Figure 3a). Brackish marsh and saltmarsh were similar to one another and stored less aboveground biomass than mangrove-dominated sites (Table 1; Figure 3). Mangrove ecosystems contained $13 \mathrm{x}$ more aboveground biomass than marsh ecosystems within 10 years of mangrove establishment, and 33x more after $75-88$ years (Table; 1 Figure 3 ). In general mangrove aboveground biomass followed an upward trajectory with age.

Mangrove biomass was similar in mangroves $<20$ years old increased to a similar level for 20-88 year old mangroves (Table 1; Figure 3). 10- 20 and 30-75 year old mangroves were also similar $(p=0.09)$.

Ecosystem type drove differences in belowground biomass $(P<0.001)$. Marsh plots had similar levels of belowground biomass to mangroves up to 20 years old (Table 2; Figure 3). However, after 20 years, mangroves contained more belowground biomass than marsh-dominated sites (Table 2; Figure 3), but there was no change in mangrove belowground biomass among 10-20 to 75-88-year-old mangrove age classes. 
Ecosystem type drove changes in soil OC stock at all depths $(p<0.001)$. In the surface soil $(0-5 \mathrm{~cm})$, brackish marsh sites had lower soil OC than any other plot type, which were all similar (Table 2; Figure 4a). Between 5 and $15 \mathrm{~cm}$ depth, soil OC was lower in brackish marsh than freshwater marshes and all mangroves except the youngest age class ( $<10$ years old) (Table 2; Figure 4b). Between 15 and $30 \mathrm{~cm}$ depth, soil OC was similar in Marshes and mangroves up to 30 years old, while mangroves $>30$ years old had higher OC than marshes (Table 2; Figure 4c). In the deepest soil depth, the oldest mangroves ( $>88$ years), had greater soil OC than any other plot type (Table 1; Figure 4d).

\section{Organic carbon fluxes}

Ecosystem-specific leaf litter $k$ differed based on ecosystem type $(p<0.001)$. Litter broke down at similar rates in each vegetation type, except that 75-88 year old mangroves had a lower breakdown rate than all but 30- 75 year old mangrove and brackish marsh $(p<0.05$; Table 3; Figure 5a). Native root $k$ in shallow soil $(0-15 \mathrm{~cm})$ and in deeper soil $(15-30 \mathrm{~cm})$ was different among ecosystem types $(p<0.001)$. Root $k$ in surface soil was faster in mangroves between 10 and 75 year old than marshes and mangroves $<10$ and $>75$ years old (Table 3 ; Figure $5 \mathrm{~b})$. In deeper soil $(15-30 \mathrm{~cm})$, roots broke down faster in mangrove plots ( $>10$ years old) than in any marsh plots (Table 3 , Figure 5c).

When using tea bags as standardized organic matter, green tea (the labile form) broke down more rapidly in marshes and mangroves established for less than 30 years $(P$ 
$<0.05)$ than older mangroves. There were no significant differences in the breakdown of red tea in each vegetation type $(p=0.1)$.

Surface accretion rates were different among ecosystem types $(p<0.001)$. Mangrove sites that have been established for more than 10 years had higher rates of accretion than marsh sites (Table 2; Figure 6a). Additionally, 30- 70 year old mangroves had higher accretion rates than $<20$ year old mangroves $(p<0.05)$, while all other mangrove types were similar ( $p>0.05$; Table 3; Figure 6a).

Root productivity was different among ecosystem types $(p=0.02)$, generally increasing with mangrove age before declining in 75- 88 year-old mangroves (Table 3; Figure 6 b). The only significant differences among ecosystem types were 10-20 year old mangroves and marshes and 30-70 year old mangroves and marshes $(p<0.05)$.

\section{DISCUSSION}

As we predicted OC storage decreased as brackish marshes experienced saltwater intrusion and transitioned to saltmarsh, before mangroves became establishment and increased OC storage through time. In particular, soil OC in saltmarsh decreased to $0.25 \mathrm{x}$ its concentration in brackish marsh and then slowly developed from the soil surface after mangroves became established. The speed of OC storage in different ecosystem components differed, with aboveground biomass increasing rapidly to $\sim 30$ times more than marsh biomass, while belowground biomass doubled. Our findings show that the interaction between saltwater intrusion and vegetation change and ecosystem development play a crucial role in coastal wetland OC storage and vulnerability during climate change. 
Vegetation change did not alter aboveground biomass among marsh types, but increased 10x within 10 years after mangrove encroachment, before stabilizing between 20 and 88 years after increasing biomass $\sim 30$ x over marsh levels. Mangrove encroachment has increased aboveground biomass along species' latitudinal limits, but functional change depends on ecosystem characteristics and mangrove encroachment often occurs in areas with variable hydrologic, climatic and edaphic conditions that can limit vegetation productivity and OC storage (Ross et al. 2000; Yando et al. 2016; Charles et al. in review). However, the western Everglades (including TTINWR) has regular tidal connectivity and, nutrient subsidies from the Gulf of Mexico, infrequent freeze events, and restored upland freshwater connectivity (Childers et al. 2006; Howard et al. 2017). The massive increase in aboveground biomass we document, greatly impacts ecosystem carbon storage. Similarly, because of the shift between foundational species with drastically different traits, mangrove encroachment is likely to impact ecosystem function in a number of ways (Van Auken et al. 2000; Kominoski et al. 2013; Guo et al. 2017).

We found a more moderate increase in root biomass with mangrove encroachment that plateaued after 20-30 years. Living and dead root accumulation often drives $\mathrm{C}$ storage and elevation change in coastal wetlands (McKee et al. 2007; McKee 2011; Deegan et al. 2012), due to slow breakdown in inundated soils (Middleton and McKee 2001). Because mangrove roots accumulated more living biomass and generally displayed greater root productivity, mangrove vegetation is likely to lead to increased soil OC storage through time. While the changes in belowground biomass we quantified along our vegetation gradient were much smaller than those aboveground, root biomass 
increased $>1 \mathrm{~kg} \mathrm{OC} \mathrm{m}^{-2}$ over 20 years and $>2.5 \mathrm{~kg} \mathrm{OC} \mathrm{m}^{-2}$ after 30 years. Because the accumulation of root biomass is essential for carbon storage and soil elevation gain (Twilley 1999; McKee et al. 2007; Chmura 2011; Deegan et al. 2012), the large increase in root biomass we quantify is likely to provide a negative feedback to climate change as well as increase coastal wetland resilience to SLR.

Climate and organic matter quality drive differences in organic matter breakdown (Cornwell et al. 2008) and we predicted that mangroves establishment would decrease breakdown rates by reducing light penetration (and temperature) after canopy closure temperature (D’Odorico et al. 2016; Charles et al. in review) and producing lower quality litter and roots (Middleton and McKee 2001; Charles et al. in review), however we found that mangrove roots and litter showed trends toward faster breakdown rates than marsh litter (Figure 5). Ecologists have frequently asked whether mangrove encroachment will alter OC storage. However, that question has often delivered a mixture of answers depending on ecosystem specific characteristic (Yando et al. 2017; Kelleway et al. 2017). Slower breakdown of mangrove than marsh litter has been documented in a number of settings due to recalcitrance (Twilley et al. 1986; Bianchi et al. 2013; Charles et al. in review). In our study, mangroves replace perennial marsh species with long-lived, highlydefended leaves (the common names "sawgrass" and "black needle rush" do a good job explaining the tough nature of these plants). Plant characteristics such as leaf longevity play a key role in vegetation function during a plant's life, and also alter their influence on the ecosystem after death, with long-lived leaves tending to breakdown slower than leaves that turnover rapidly (Cornwell et al. 2008). Aboveground structure also governs OM breakdown through alteration of microclimate. Breakdown is increased at higher 
temperatures (Brown et al. 2004; Fierer et al. 2005), and as mangrove canopy closes, it shades soil and reduces peak soil temperatures (D'Odorico et al. 2013), often reducing organic matter breakdown (Charles et al. in review). Another crucial difference between marsh and mangrove breakdown rates is that mangroves not only contributes litter to the soil surface, but also deposits woody biomass, which is very slow to breakdown (Krauss et al. 2005; Middleton and McKee 2001).

Similarly, we predicted that mangrove roots would be more recalcitrant than marsh roots (Charles et al. in review), but we found that in general mangrove roots broke down more rapidly than marsh roots. Again, this likely due to specific plant traits. Mangroves are known to be more efficient at transporting oxygen to their roots than many marsh plants including C. jamaicense (Gill and Tomlinson 1977; Chabbi et al. 2000), indicating that roots are less dense and potentially more prone to breakdown. Additionally, we predicted that due to greater soil aeration, mangroves might enhance belowground breakdown, but our standard substrates generally showed the opposite, with breakdown rates of green tea lower in older mangrove ecosystems. We predicted that mangrove roots would increase organic matter loss during their early colonization by priming existing organic matter in the soil (Gill and Tomlinson 1977; Kuzyakov et al. 2010), but the recalcitrant roots would build up over time (McKee et al. 2007). Instead we found that soil OC losses occurred before mangrove encroachment, indicating that plant-soil feedbacks associated with saltwater intrusion, rather than mangrove encroachment, was responsible for soil OC loss (Weston et al. 2006; Neubauer 2013; Chambers et al. 2013). Additionally, because mangroves promote OC storage, they 
create a feedback to more reduced conditions, slower breakdown rates and therefore greater OC storage.

We also predicted that mangrove encroachment would increase surface accretion by enhancing autochthonous productivity and sediment trapping, which proved to be true. Both marsh plants and mangroves baffle current and wave energy and trap sediments (Fagherazzi et al. 2006), but in some ecosystems, mangroves are more efficient at trapping sediment (Witman et al. 2004) as mangrove roots and pneumatophores promote sedimentation (Young and Harvey 1996). Sediment is important for soil accretion, the burial and sequestration of OC and as a nutrient source (Bouillion et al. 2008). However, dense mangroves may intercept the majority of allochthonous materials at the community boundary, preventing it from accessing the marsh interior (Charles et al. in prep), but because all sites were located more than a kilometer from the coast, coastal subsidies are unlikely to play a large role.

We found that mangrove root productivity increased with mangrove encroachment, but decreased in the oldest mangrove ecosystems, demonstrating peak belowground productivity in developing ecosystems. Allocation to high root:shoot productivity ratios are common in halophytes in general (Good et al. 1982), and particularly to mangroves (Lugo 1990; Naidoo 2009). On the other hand, marshes dominated by $C$. jamaicense produce 4.6 times more biomass above than belowground (Lorenzen 2001). Odum (1969) suggests that as ecosystems develop they expend less energy on productivity and more on maintenance. Furthermore, Tilman (1985) suggests that plants expend energy to obtain the resource that is most limiting their growth. The combination of these two theories likely explains the trends in biomass and productivity 
that we see in TTINWR. Upon early colonization, mangroves rapidly colonize marshes at high densites ( $>10$ mangroves per $\mathrm{m}^{2}$ ) driving inter- and intra-specific competition for light. Meanwhile we show that OC decomposes and vegetation communities turn over rapidly during saltwater intrusion, leading to nutrient availability. As mangroves become more established, they self-thin to lower densities and as they deplete soil nutrients, they expend more energy on root productivity. However, the oldest mangroves reduce their root productivity to focus energy on biomass maintenance. Perhaps this explains the low root productivity in young mangroves, the peak in root productivity at intermediate age classes and then the decline with advanced age.

Ecosystem development also leads to the accumulation of soil OC through aboveground woody vegetation turnover. Woody material is very slow to breakdown (Krauss et al. 2005), and as ecosystems developed in TTINWR, we found evidence of widespread turnover of aboveground mangrove biomass. Young mangrove forests in TTINWR had very high density of white mangroves $\left(>10 \mathrm{~m}^{2}\right)$, which eventually decreased to $\left(<0.2 \mathrm{~m}^{2}\right)$. Similarly, young mangrove forests were dominated by white mangroves, but as mangroves aged we documents a transition to more red and black mangroves. We witnessed large level of dead wood on the soil surface in older mangroves, and no overall change in total aboveground biomass between 30 and 88 years of mangrove development. This indicates that some of the increase in soil OC stock is likely the result of turnover of aboveground woody biomass.

The nature of mangrove encroachment is drastically different in TTINWR than in the Southeast Saline Everglades (SSE). Both are experiencing saltwater intrusion and drastic mangrove encroachment (Ross et al. 2000; Krauss et al. 2011), but in the 
Southeast Everglades landscape change has led to the expansion of a zone of lowbiomass as marsh vegetation is lost and mangrove encroachment proceeds in a heterogenous nature across the landscape. On the other hand, mangroves in TTINWR have largely encroached into existing saltmarsh, without a temporal or spatial disparity between marsh loss and mangrove encroachment. Furthermore, mangrove forests in TTINWR develop much more biomass than in the SSE, indicating that they likely have a much greater structural and functional impact.

Saltwater intrusion and vegetation change are causing massive changes in coastal ecosystems (Sutter et al. 2013; Herbert et al. 2015), including mangrove encroachment into marsh ecosystems in Australia (Rogers et al. 2006; Winn et al. 2006), Mexico (Lopez-Medellin et al. 2011), and the United States (Ross et al. 2000; Smith et al. 2013). This study documented a decrease in OC stocks during saltwater intrusion, followed by large gains in plant and soil OC stocks as mangrove ecosystems develop. In TTINWR, mangroves expanded their range inland by 35\% between 1927 and 2005 at the expense of marsh (Krauss et al. 2011), and mangroves continue to invade marshes in very high densities. TTINWR has experienced the expansion of open water ponds over the past half century in areas experiencing saltwater intrusion, but the Comprehensive Everglades Restoration Project (CERP) aims to increase freshwater flow and may decrease average salinities from 18 to 10 psu throughout marshes of TTINWR (Michot et al. 2015). By reducing saltwater intrusion and maintaining brackish marsh conditions, mangroves may have greater time to invade and develop before OC loss as marshes experience saltwater intrusion. Our study shows that coastal wetlands are most vulnerable during saltwater 
intrusion, but before mangrove encroachment and development. Our research shows that mangrove establishment and time to develop will increase marsh resilience to SLR.

\section{ACKNOWLEDGMENTS}

Funding for this research was provided by an NSF Doctoral Dissertation Improvement Grant (\#800006578), and an FIU ForEverglades fellowship from The Everglades Foundation. We thank Rookery Bay National Estuarine Research Reserve for information, feedback and support in the form of kayaks, lodging and lab space. We thank Ten Thousand Islands National Wildlife Reserve for site access, local knowledge and occasional airboat transportation.

\section{LITERATURE CITED}

Brown, J. H., J. F. Gillooly, A. P. Allen, V. M. Savage and G. B. West. Toward a metabolic theory of ecology. Ecology 85:1771-1789.

Cahoon, D. R., and R. E. Turner. 1989. Accretion and canal impacts in a rapidly subsiding wetland: feldspar marker horizon technique. Estuaries 12:260-268.

Chabbi, A., K.L. McKee, I. A. Mendelssohn. 2000. Fate of oxygen losses from Typha domingensis (Typhaceae) and Cladium jamaicense (Cyperaceae) and consequences for root metabolism. American Journal of Botany 87:1081-1090.

Chambers, L. G., S. E. Davis, T. Troxler, J. N. Boyer, A. Downey-Wall, and L. J. Scinto. 2014. Biogeochemical effects of simulated sea level rise on carbon loss in an Everglades mangrove peat soil. Hydrobiologia 726:195-211.

Chmura, G. L., S. C. Anisfeld, D. R. Cahoon, and J. C. Lynch. 2003. Global carbon sequestration in tidal, saline wetland soils. Global Biogeochemical Cycles 17:12.

Cornwell, W. K., J. H. C. Cornelissen, K. Amatangelo, E. Dorrepaal, V. T. Eviner, O. Godoy, S. E. Hobbie, B. Hoorens, H. Kurokawa, N. Perez-Harguindeguy, H. M. Quested, L. S. Santiago, D. A. Wardle, I. J. Wright, R. Aerts, S. D. Allison, P. van 
Bodegom, V. Brovkin, A. Chatain, T. V. Callaghan, S. Diaz, E. Garnier, D. E. Gurvich, E. Kazakou, J. A. Klein, J. Read, P. B. Reich, N. A. Soudzilovskaia, M. V. Vaieretti, and M. Westoby. 2008. Plant species traits are the predominant control on litter decomposition rates within biomes worldwide. Ecology Letters 11:1065-1071.

Costanza, R., R. de Groot, P. Sutton, S. van der Ploeg, S. J. Anderson, I. Kubiszewski, S. Farber, and R. K. Turner. 2014. Changes in the global value of ecosystem services. Global Environmental Change-Human and Policy Dimensions 26:152158.

D'Odorico, P., Y. F. He, S. Collins, S. F. J. De Wekker, V. Engel, and J. D. Fuentes. 2013. Vegetation-microclimate feedbacks in woodland-grassland ecotones. Global Ecology and Biogeography 22:364-379.

Elridge DJ, Bowker MA, Maestre FT, Roger E, Reynolds JF and Whitford WG. Impacts of shrub encroachment on ecosystem structure and functioning: towards a global synthesis. Ecology Letters 14:709-722.

Fagherazzi, S., L. Carniello, L. D'Alpaos, and A. Defina. 2006. Critical bifurcation of shallow microtidal landforms in tidal flats and salt marshes. Proceedings of the National Academy of Sciences of the United States of America 103:8337-8341.

Fierer, N., J. M. Craine, K. McLauchlan, and J. P. Schimel. 2005. Litter quality and the temperature sensitivity of decomposition. Ecology 86:320-326.

Guo, H., C. Weaver, S. P. Charles, A. Whitt, S. Dastidar, P. D'Odorico, J. D. Fuentes, J. S. Kominoski, A. R. Armitage, and S. C. Pennings. 2017. Coastal regime shifts: rapid responses of coastal wetlands to changes in mangrove cover. Ecology 98:762-772.

Herbert, E. R., P. Boon, A. J. Burgin, S. C. Neubauer, R. B. Franklin, M. Ardon, K. N. Hopfensperger, L. P. M. Lamers, and P. Gell. 2015. A global perspective on wetland salinization: ecological consequences of a growing threat to freshwater wetlands. Ecosphere 6:43.

Kelleway, J. J., K. Cavanaugh, K. Rogers, I. C. Feller, E. Ens, C. Doughty, and N. Saintilan. 2017. Review of the ecosystem service implications of mangrove encroachment into salt marshes. Global Change Biology 23:3967-3983.

Keuskamp, J. A., B. J. J. Dingemans, T. Lehtinen, J. M. Sarneel, and M. M. Hefting. 2013. Tea Bag Index: a novel approach to collect uniform decomposition data across ecosystems. Methods in Ecology and Evolution 4:1070-1075. 
Kirwan, M. L., and J. P. Megonigal. 2013. Tidal wetland stability in the face of human impacts and sea-level rise. Nature 504:53-60.

Kirwan, M. L., S. Temmerman, E. E. Skeehan, G. R. Guntenspergen, and S. Fagherazzi. 2016. Overestimation of marsh vulnerability to sea level rise. Nature Climate Change 6:253-260.

Knapp, A. K., J. M. Briggs, S. L. Collins, S. R. Archer, M. S. Bret-Harte, B. E. Ewers, D. P. Peters, D. R. Young, G. R. Shaver, E. Pendall, and M. B. Cleary. 2008. Shrub encroachment in North American grasslands: shifts in growth form dominance rapidly alters control of ecosystem carbon inputs. Global Change Biology 14:615623.

Kominoski, J. S., J. J. F. Shah, C. Canhoto, D. G. Fischer, D. P. Giling, E. Gonzalez, N. A. Griffiths, A. Larranaga, C. J. LeRoy, M. M. Mineau, Y. R. McElarney, S. M. Shirley, C. M. Swan, and S. D. Tiegs. 2013. Forecasting functional implications of global changes in riparian plant communities. Frontiers in Ecology and the Environment 11:423-432.

Krauss, K. W., T. W. Doyle, R. R. Twilley, T. J. Smith, K. R. T. Whelan, and J. K. Sullivan. 2005. Woody debris in the mangrove forests of South Florida. Biotropica 37:9-15.

Krauss, K. W., J. A. Duberstein, T. W. Doyle, W. H. Conner, R. H. Day, L. W. Inabinette, and J. L. Whitbeck. 2009. Site condition, structure, and growth of baldcypress along tidal/non-tidal salinity gradients. Wetlands 29:505-519.

Kuzyakov, Y. 2010. Priming effects: Interactions between living and dead organic matter. Soil Biology \& Biochemistry 42:1363-1371.

López-Medellín, X., E. Ezcurra, C. González-Abraham, J. Hak, L.S. Santiago and J.O. Sickman. 2011. Oceanographic anomalies and sea-level rise drive mangroves inland in the Pacific coast of Mexico. Journal of Vegetation Science 22:143-151.

McKee, K. L., D. R. Cahoon, and I. C. Feller. 2007. Caribbean mangroves adjust to rising sea level through biotic controls on change in soil elevation. Global Ecology and Biogeography 16:545-556.

McLeod, E., G. L. Chmura, S. Bouillon, R. Salm, M. Bjork, C. M. Duarte, C. E. Lovelock, W. H. Schlesinger, and B. R. Silliman. 2011. A blueprint for blue carbon: toward an improved understanding of the role of vegetated coastal habitats in sequestering CO2. Frontiers in Ecology and the Environment 9:552560 . 
Michot, B. D., E. A. Meselhe, A. M. Asce, K. W. Krauss, S. Shrestha. 2017. Hydrologic modeling in a marsh-mangrove ecotone: predicting wetland wurface water and salinity response to restoration in the Ten Thousand Islands region of Florida, USA. Journal of Hydrological Engineering 22:

Middleton, B. A., and K. L. McKee. 2001. Degradation of mangrove tissues and implications for peat formation in Belizean island forests. Journal of Ecology 89:818-828.

Morris, J. T., D. C. Barber, J. C. Callaway, R. Chambers, S. C. Hagen, C. S. Hopkinson, B. J. Johnson, P. Megonigal, S. C. Neubauer, T. Troxler, and C. Wigand. 2016. Contributions of organic and inorganic matter to sediment volume and accretion in tidal wetlands at steady state. Earths Future 4:110-121.

Mueller-Dombois D., H. Ellenberg. 1974. Aims and methods of vegetation ecology. Wiley, London, UK.

Nerem, R. S., B. D. Beckley, J. T. Fasullo, B. D. Hamlington, D. Masters, and G. T. Mitchum. 2018. Climate-change-driven accelerated sea-level rise detected in the altimeter era. Proceedings of the National Academy of Sciences of the United States of America 115:2022-2025.

Neubauer, S. C. 2008. Contributions of mineral and organic components to tidal freshwater marsh accretion. Estuarine Coastal and Shelf Science 78:78-88.

Neubauer, S. C. 2013. Ecosystem Responses of a Tidal Freshwater Marsh Experiencing Saltwater Intrusion and Altered Hydrology. Estuaries and Coasts 36:491-507.

Noe, G. B., K. W. Krauss, B. G. Lockaby, W. H. Conner and C. R. Hupp. 2013. The effect of increasing salinity and forest mortality on soil nitrogen and phosphorus mineralization in tidal freshwater forested wetlands. Biogeochemistry 114:225244.

Nyman, J. A., R. J. Walters, R. D. Delaune, and W. H. Patrick. 2006. Marsh vertical accretion via vegetative growth. Estuarine Coastal and Shelf Science 69:370-380.

Osland, M. J., A. C. Spivak, J. A. Nestlerode, J. M. Lessmann, A. E. Almario, P. T. Heitmuller, M. J. Russell, K. W. Krauss, F. Alvarez, D. D. Dantin, J. E. Harvey, A. S. From, N. Cormier, and C. L. Stagg. 2012. Ecosystem Development After Mangrove Wetland Creation: Plant-Soil Change Across a 20-Year Chronosequence. Ecosystems 15:848-866.

Rogers, K., K. M. Wilton and N. Saintilan. Vegetation change and surface elevation dynamics in estuarine wetlands of southeast Australia. 2006. Estuarine, Coastal and Shelf Science 66:559-569. 
Ross, M. S., J. F. Meeder, J. P. Sah, P. L. Ruiz, and G. J. Telesnicki. 2000. The Southeast Saline Everglades revisited: 50 years of coastal vegetation change. Journal of Vegetation Science 11:101-112.

Smith, T. J., A. M. Foster, G. Tiling-Range, and J. W. Jones. 2013. Dynamics of mangrove-marsh ecotones in subtropical coastal wetlands: fire, sea-level rise, and water levels. Fire Ecology 9:66-77.

Sutter, L. A., J. E. Perry and R. M. Chambers. 2014. Tidal freshwater marsh plant responses to low level salinity increases. Wetlands 34:167-175.

Tilman, D. 1985. The resource-ratio hypotheis of plant sucession. American Naturalist 125:827-852.

Twilley, R. R., A. E. Lugo, and C. Pattersonzucca. 1986. Litter production and turnober in basin mangrove forests in Southwest Florida. Ecology 67:670-683.

Van Auken, O. W. 2000. Shrub invasions of North American semiarid grasslands. Annual Review of Ecology and Systematics 31:197-215.

Vogt, K. A., D. J. Vogt, and J. Bloomfield. 1998. Analysis of some direct and indirect methods for estimating root biomass and production of forests at an ecosystem level. Plant and Soil 200:71-89.

Weston, N. B., M. A. Vile, S. C. Neubauer, and D. J. Velinsky. 2011. Accelerated microbial organic matter mineralization following salt-water intrusion into tidal freshwater marsh soils. Biogeochemistry 102:135-151.

White, E., and D. Kaplan. 2017. Restore or retreat? saltwater intrusion and water management in coastal wetlands. Ecosystem Health and Sustainability.

Woodroffe, C. D. 1990. The impact of sea-level rise on mangrove shorelines. Progress in Physical Geography 14:483-520.

Yando, E. S., M. J. Osland, J. M. Willis, R. H. Day, K. W. Krauss, and M. W. Hester. 2016. Salt marsh-mangrove ecotones: using structural gradients to investigate the effects of woody plant encroachment on plant-soil interactions and ecosystem carbon pools. Journal of Ecology 104:1020-1031.

Young, B. M. and L. E. Harvey. 1996. A spatial analysis of the relationship between mangrove (Avicenia marina var. australasica) physiognomy and sediment accretion in the Hauraki Plains, New Zealand. Estuarine, Coastal and Shelf Science 42: 231-2 
Table 1. Mean and SE of aboveground biomass in ecosystem types. We show total, total herbaceous and species-specific woody plant biomass as $\mathrm{OC} \mathrm{m}^{2}$, and the proportion of total aboveground biomass contributed by each mangrove species.

\begin{tabular}{|c|c|c|c|c|c|c|c|c|c|c|c|c|c|}
\hline Site & $\begin{array}{c}\text { Total } \\
\text { biomas } \\
\text { s (kg m } \\
2 \\
2\end{array}$ & SE & $\begin{array}{c}\text { Herbaceou } \\
\mathrm{s} \text { biomass } \\
\left(\mathrm{kg} \mathrm{m}^{-2}\right) \\
\end{array}$ & SE & $\begin{array}{c}L . \\
\text { racemos } \\
\quad a \\
\text { biomass } \\
\left(\mathrm{kg} \mathrm{m}^{-2}\right) \\
\end{array}$ & SE & $\begin{array}{c}L . \\
\text { racemosa } \\
\text { proportio } \\
\mathrm{n} \text { total } \\
\text { biomass } \\
\end{array}$ & $\begin{array}{c}R . \\
\text { mangle } \\
\text { biomas } \\
\mathrm{s}\left(\mathrm{kg} \mathrm{m}^{-}\right. \\
2) \\
\end{array}$ & SE & $\begin{array}{c}\text { R. mangle } \\
\text { proportio } \\
\mathrm{n} \text { total } \\
\text { biomass } \\
\end{array}$ & $\begin{array}{c}A . \\
\text { germinan } \\
s \text { biomass } \\
\left(\mathrm{kg} \mathrm{m}^{-2}\right) \\
\end{array}$ & SE & $\begin{array}{c}A . \\
\text { germinans } \\
\text { proportio } \\
\text { n total } \\
\text { biomass } \\
\end{array}$ \\
\hline \multirow{3}{*}{$\begin{array}{l}\text { Brackish } \\
\text { marsh }\end{array}$} & & 0.51 & & 0.51 & & & & & & & & & \\
\hline & 1.300 & 1 & 1.298 & 1 & 0 & 0 & & 0 & 0 & 0 & 0 & 0 & 0 \\
\hline & & 0.04 & & 0.09 & & 0.00 & & & & & & & \\
\hline Saltmarsh & 0.700 & 0 & 0.556 & 7 & 0.014 & 1 & 0.020 & 0 & 0 & 0 & 0 & 0 & 0 \\
\hline \multicolumn{14}{|l|}{ Mangrov } \\
\hline e 1 (0- 10 & & 1.88 & & 0.32 & & 1.96 & & & 1.05 & & & & \\
\hline years) & 13.050 & 0 & 0.335 & 2 & 11.565 & 7 & 0.886 & 1.053 & 3 & 0.081 & 0 & 0 & 0 \\
\hline \multicolumn{14}{|l|}{ Mangrov } \\
\hline e 2 (10-20 & & 3.42 & & 0.00 & & 2.14 & & & 0.22 & & & & \\
\hline years) & 15.260 & 0 & 0.030 & 0 & 12.594 & 7 & 0.825 & 0.504 & 3 & 0.033 & 0 & 0 & 0 \\
\hline \multicolumn{14}{|l|}{ Mangrov } \\
\hline e 3 (20-30 & & 3.03 & & 0.00 & & 3.76 & & & 6.63 & & & & \\
\hline years) & 24.430 & 0 & 0.010 & 4 & 7.331 & 8 & 0.300 & 12.426 & 2 & 0.509 & 0 & 0 & 0 \\
\hline \multicolumn{14}{|l|}{ Mangrov } \\
\hline e 4 (30-70 & & 2.96 & & 0.00 & & 0.77 & & & 3.19 & & & & \\
\hline years) & 20.050 & 0 & 0.000 & 0 & 9.667 & 7 & 0.482 & 8.156 & 6 & 0.407 & 0 & 0 & 0 \\
\hline \multicolumn{14}{|l|}{ Mangrov } \\
\hline e 5 (75- & & 4.19 & & 0.30 & & 1.83 & & & 1.69 & & & 0.29 & \\
\hline 88 years) & 33.220 & 0 & 0.010 & 0 & 9.448 & 0 & 0.284 & 9.829 & 1 & 0.296 & 9.778 & 5 & 0.294 \\
\hline
\end{tabular}


Table 2. Mean and SE of belowground OC stocks in each ecosystem type. OC stocks are separated into belowground biomass stock and proportion OC by mass in each soil depth.

\begin{tabular}{|c|c|c|c|c|c|c|c|c|c|c|}
\hline Site & $\begin{array}{c}\text { Belowground } \\
\text { biomass }\end{array}$ & SE & $\begin{array}{l}\text { Soil OC } \\
(0-5 \mathrm{~cm})\end{array}$ & SE & $\begin{array}{c}\text { Soil OC } \\
(5-15 \mathrm{~cm})\end{array}$ & SE & $\begin{array}{c}\text { Soil OC } \\
(15-30 \\
\mathrm{cm}) \\
\end{array}$ & SE & $\begin{array}{c}\text { Soil } \\
\text { OC } \\
(30-45 \\
\mathrm{cm}) \\
\end{array}$ & SE \\
\hline $\begin{array}{l}\text { Brackish } \\
\text { marsh }\end{array}$ & 1.49 & 0.24 & 0.378 & 0.002 & 0.325 & 0.06 & 0.035 & 0.004 & 0.009 & 0.0008 \\
\hline Saltmarsh & 1.64 & 0.33 & 0.101 & 0.044 & 0.031 & 0.009 & 0.025 & 0.012 & 0.012 & 0.005 \\
\hline $\begin{array}{l}\text { Mangrove } 1 \\
\text { (0-10 years) }\end{array}$ & 1.53 & 0.26 & 0.282 & 0.057 & 0.131 & 0.026 & 0.01 & 0.001 & 0.011 & 0.002 \\
\hline $\begin{array}{l}\text { Mangrove } 2 \\
\text { (10-20 } \\
\text { years) }\end{array}$ & 2.81 & 0.33 & 0.386 & 0.008 & 0.29 & 0.059 & 0.149 & 0.04 & 0.014 & 0.0001 \\
\hline $\begin{array}{l}\text { Mangrove } 3 \\
\text { (20-30 } \\
\text { years) }\end{array}$ & 4.24 & 0.51 & 0.378 & 0.008 & 0.209 & 0.027 & 0.112 & 0.063 & 0.023 & 0.009 \\
\hline $\begin{array}{l}\text { Mangrove } 4 \\
\text { (30-70 } \\
\text { years) }\end{array}$ & 4.42 & 0.93 & 0.374 & 0.009 & 0.323 & 0.012 & 0.351 & 0.058 & 0.035 & 0.009 \\
\hline $\begin{array}{l}\text { Mangrove } 5 \\
\text { ( } 75-88 \\
\text { years) }\end{array}$ & 3.91 & 0.71 & 0.299 & 0.089 & 0.345 & 0.008 & 0.35 & 0.089 & 0.267 & 0.083 \\
\hline
\end{tabular}


Table 3. Mean and SE of soil fluxes for each ecosystem type. We show breakdown rates of ecosystem specific leaves and roots calculated from loss of ash free dry mass over 1 year. Surface accretion is elevation change over one year, and root productivity in organic carbon inputs per year.

\begin{tabular}{|c|c|c|c|c|c|c|c|c|c|c|}
\hline Site & $\begin{array}{c}\text { Litter } \\
\text { breakdown } \\
\left(k d^{-1}\right)\end{array}$ & SE & $\begin{array}{c}\text { Root } \\
\text { breakdown } \\
\left(k d^{-1}\right)(0- \\
15 \mathrm{~cm}) \\
\end{array}$ & SE & $\begin{array}{c}\text { Root } \\
\text { breakdown } \\
\left(k d^{-1}\right)(15- \\
30 \mathrm{~cm}) \\
\end{array}$ & SE & $\begin{array}{l}\text { Surface } \\
\text { accretion } \\
\text { (mm yr) }\end{array}$ & SE & 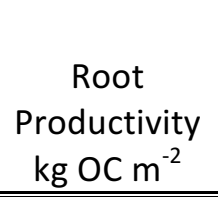 & SE \\
\hline $\begin{array}{l}\text { Brackish } \\
\text { marsh }\end{array}$ & 0.0023 & 0.00034 & 0.00092 & 0.00029 & 0.00079 & 0.00035 & 2.94 & 1.44 & 0.29 & 0.07 \\
\hline $\begin{array}{l}\text { Saltmarsh } \\
\text { Mangrove }\end{array}$ & 0.003 & 0.00026 & 0.001 & 0.00018 & 0.00073 & 0.00006 & 1.17 & 0.4 & 0.27 & 0.07 \\
\hline $\begin{array}{l}1 \text { (0-10 } \\
\text { years) } \\
\text { Mangrove }\end{array}$ & 0.0028 & 0.00016 & 0.0013 & 0.0003 & 0.00121 & 0.00016 & 1.72 & 0.22 & 0.33 & 0.05 \\
\hline $\begin{array}{l}2 \text { (10-20 } \\
\text { years) } \\
\text { Mangrove }\end{array}$ & 0.00277 & 0.00014 & 0.0025 & 0.0001 & 0.0023 & 0.0002 & 2.28 & 0.25 & 0.46 & 0.05 \\
\hline $\begin{array}{l}3(20-30 \\
\text { years) } \\
\text { Mangrove }\end{array}$ & 0.00314 & 0.00018 & 0.0022 & 0.00023 & 0.00183 & 0.00026 & 2.56 & 0.44 & 0.43 & 0.07 \\
\hline $\begin{array}{l}4 \text { (30-70 } \\
\text { years) } \\
\text { Mangrove }\end{array}$ & 0.0023 & 0.0002 & 0.0025 & 0.00023 & 0.00204 & 0.00024 & 3.72 & 0.46 & 0.48 & 0.06 \\
\hline $\begin{array}{l}5(75-88 \\
\text { years) }\end{array}$ & 0.0017 & 0.00011 & 0.0016 & 0.00015 & 0.0011 & 0.0001 & 2 & 0.26 & 0.23 & 0.03 \\
\hline
\end{tabular}


Figure 1. Conceptual model showing a reduction in soil $\mathrm{C}$ pools with salinity intrusion when vegetation community remains the same (represented by $\mathrm{C}$ with green arrows). Marsh OC storage decreases with saltwater intrusion, but the rate and trend of decrease are unclear. The establishment of halophytes (represented by $\mathrm{C}$ with red yellow and blue arrows) and their development through time could lead to increased C loss, recovery or net $\mathrm{C}$ sequestration through time. In Ten Thousand Islands National Wildlife Refuge, the halophytes that become established are mostly mangroves which store OC, potentially replacing and surpassing marsh OC through time.

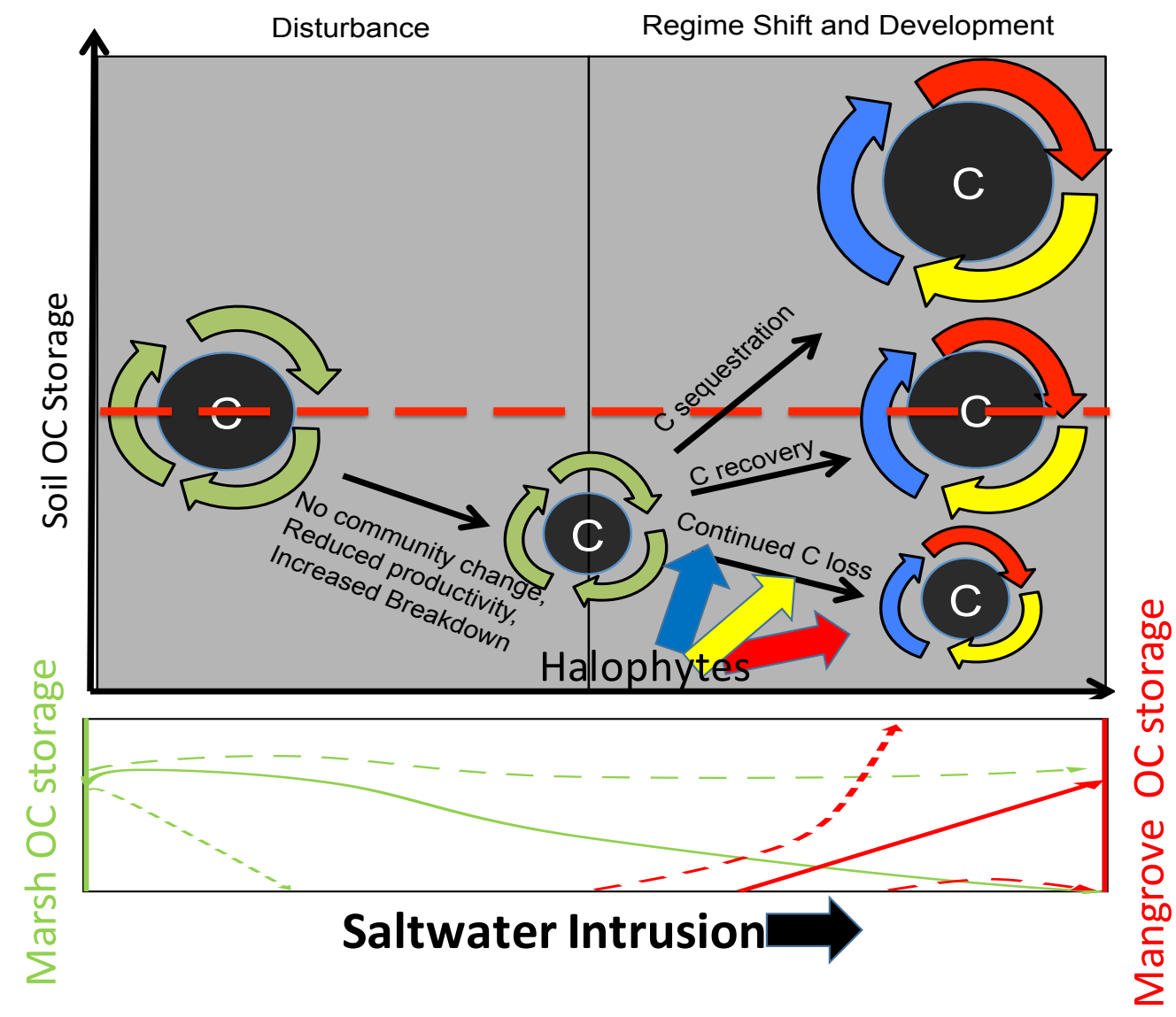


Figure 2. Images of our experimental setting and mangrove encroachment. We increasingly focus in on our study area, beginning with A. the location of Ten Thousand Islands National Wildlife Refuge (TTINWR), B. mangrove extent in TTINWR in 1927, 1940 and 2006 based on aerial photography, C. two of our transects, illustrating different plot types, across a landscape of shifting vegetation D. the change in mangrove cover from 2006 to 2016 based on historical aerial imagery and E. displaying the view from the brackish marsh, looking toward mangroves of increasing age, including a photo of mangrove seedlings in the marsh understory.

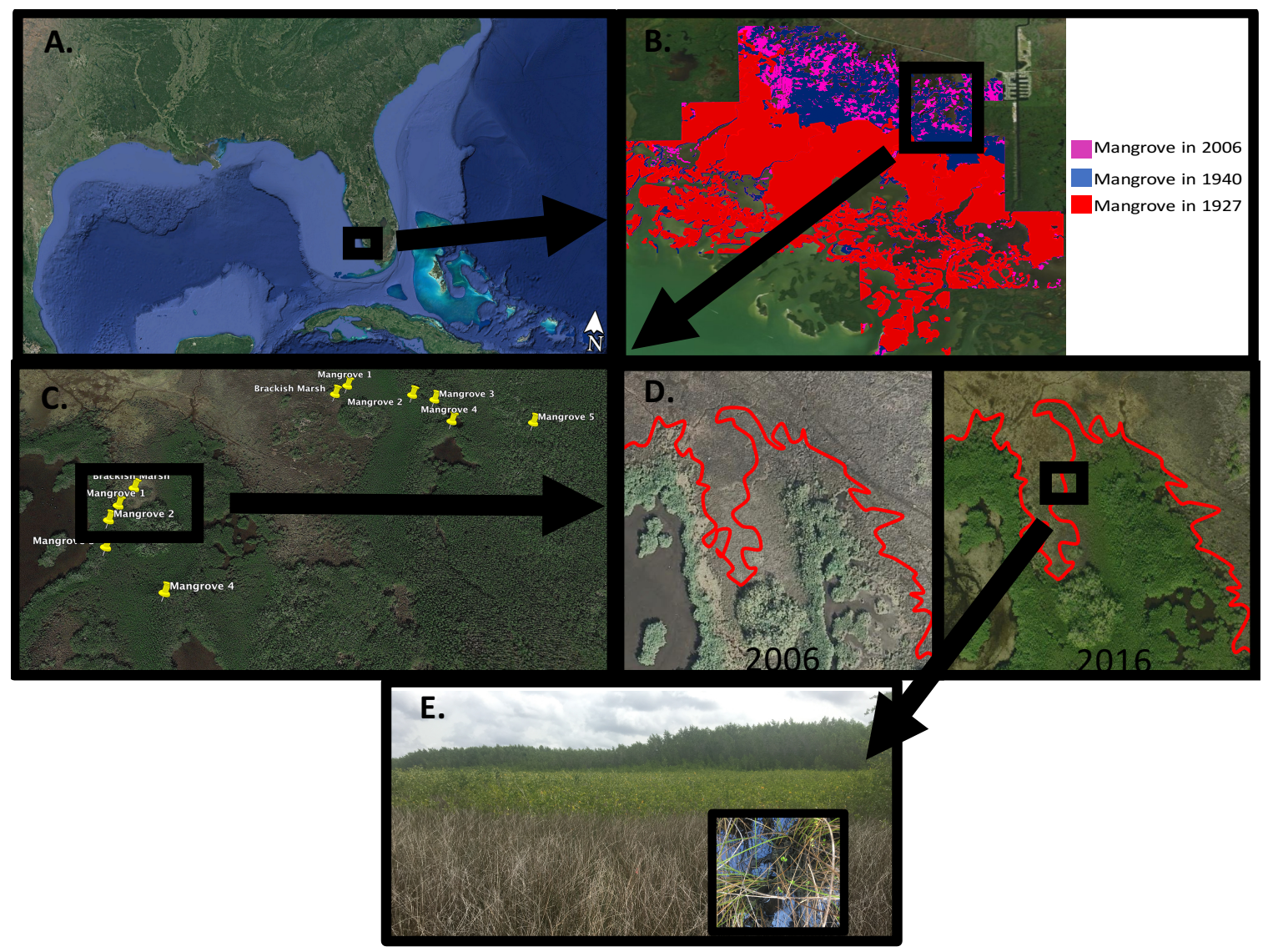


Figure 3. Organic carbon stocks in A. aboveground biomass and B. belowground biomass in each ecosystem type. Mangrove classes are Mangrove 1 (0-10 years old), Mangrove 2 (10-20 years old), Mangrove 3 (20-30 years old), Mangrove 4 (30-70 years old), Mangrove 5 (75-88 years old). Letters represent differences in ecosystem type based on Tukey HSD tests, with significant differences for $p<0.05$.
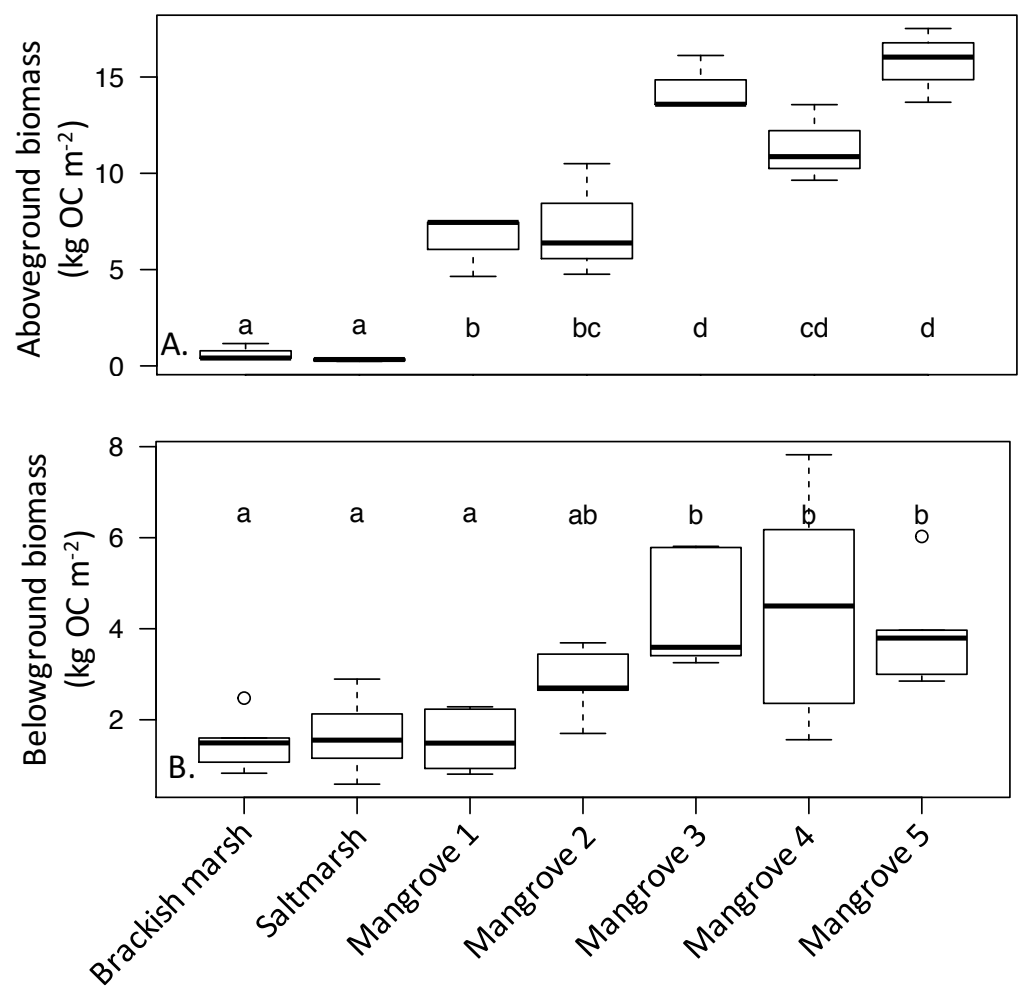
Figure 4. Proportion organic by mass in soil at A. 0-5 cm soil depth B. 5-15 cm soil depth C. 15-30 cm soil depth and D. 30-45 cm soil depth. Mangrove classes are Mangrove 1 (0-10 years old), Mangrove 2 (10-20 years old), Mangrove 3 (20-30 years old), Mangrove 4 (30-70 years old), Mangrove 5 (75-88 years old). Letters represent differences in ecosystem type based on Tukey HSD tests, with significant differences for $p<0.05$.
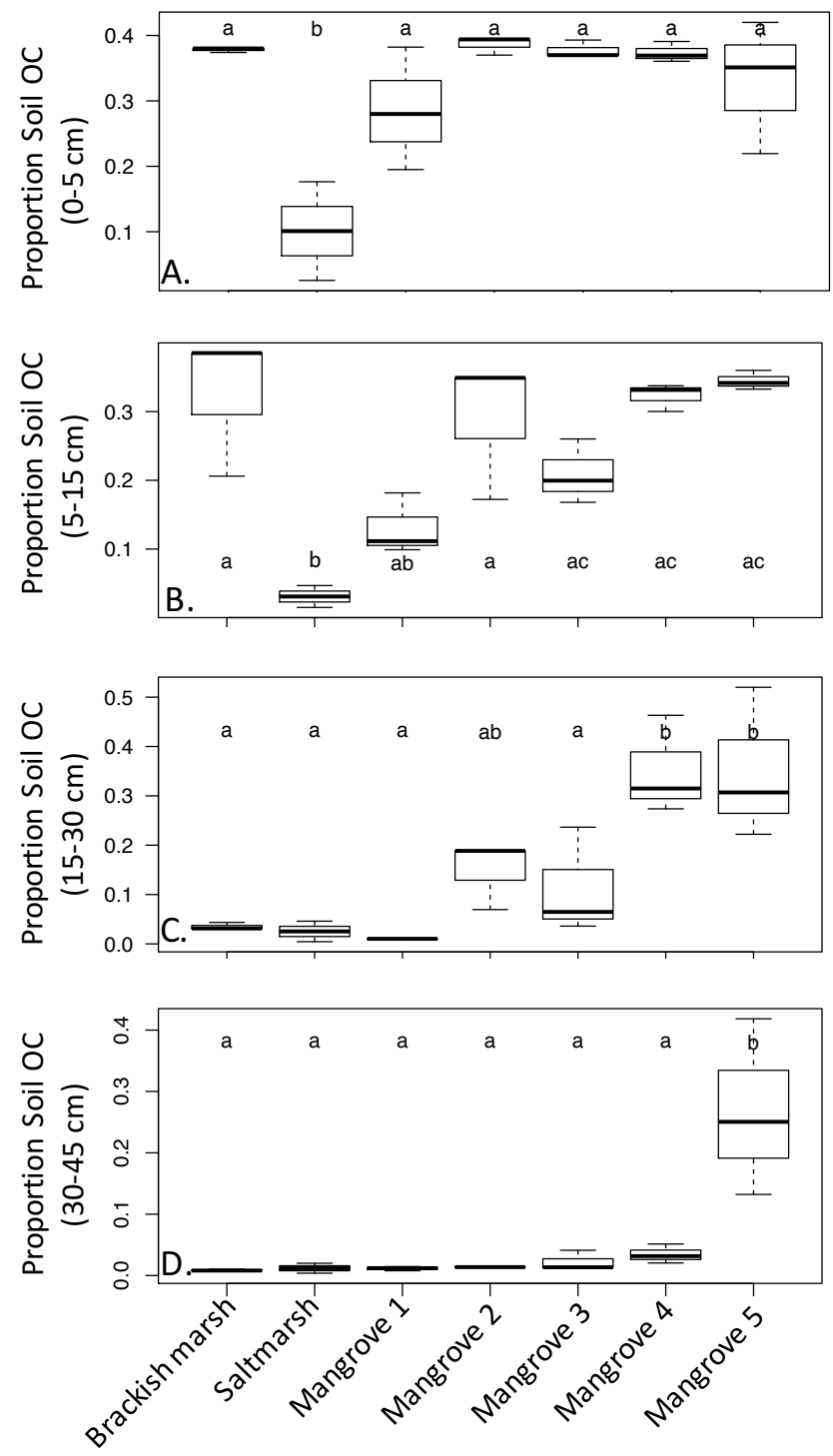
Figure 5. Organic matter breakdown rates expressed as $k \mathrm{~d}^{-1}$ of ash free dry mass for A. leaf litter on the soil surface B. 0-15 cm deep roots and C. 15-30 $\mathrm{cm}$ deep roots.

Mangrove classes are Mangrove 1 (0-10 years old), Mangrove 2 (10-20 years old), Mangrove 3 (20-30 years old), Mangrove 4 (30-70 years old), Mangrove 5 (75-88 years old). Letters represent differences in ecosystem type based on Tukey HSD tests, with significant differences for $p<0.05$.
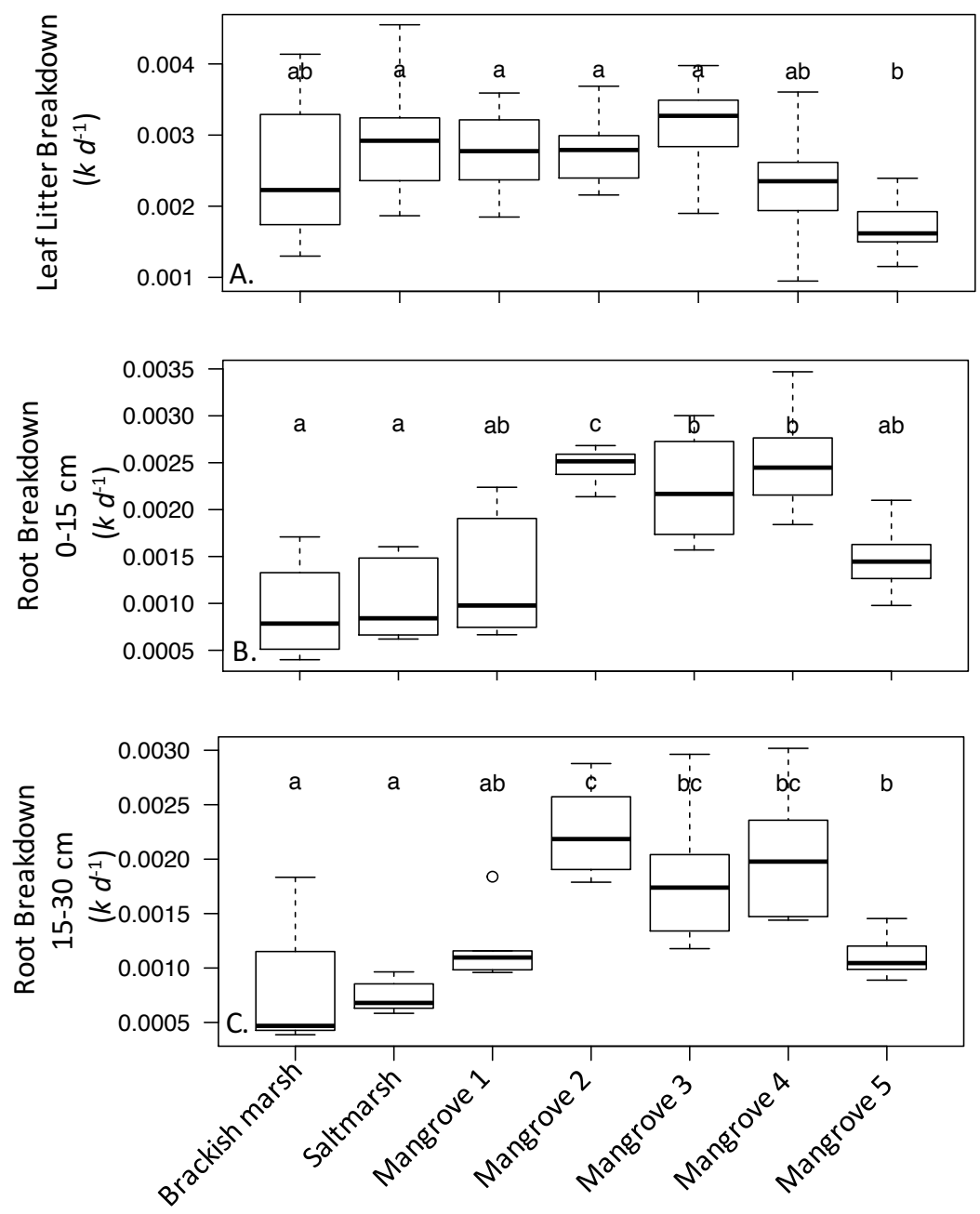
Figure 6. Soil inputs of A. total surface accretion B. organic carbon inputs as root productivity. Mangrove classes are Mangrove 1 (0-10 years old), Mangrove 2 (10-20 years old), Mangrove 3 (20-30 years old), Mangrove 4 (30-70 years old), Mangrove 5 (75-88 years old). Letters represent differences in ecosystem type based on Tukey HSD tests, with significant differences for $p<0.05$.
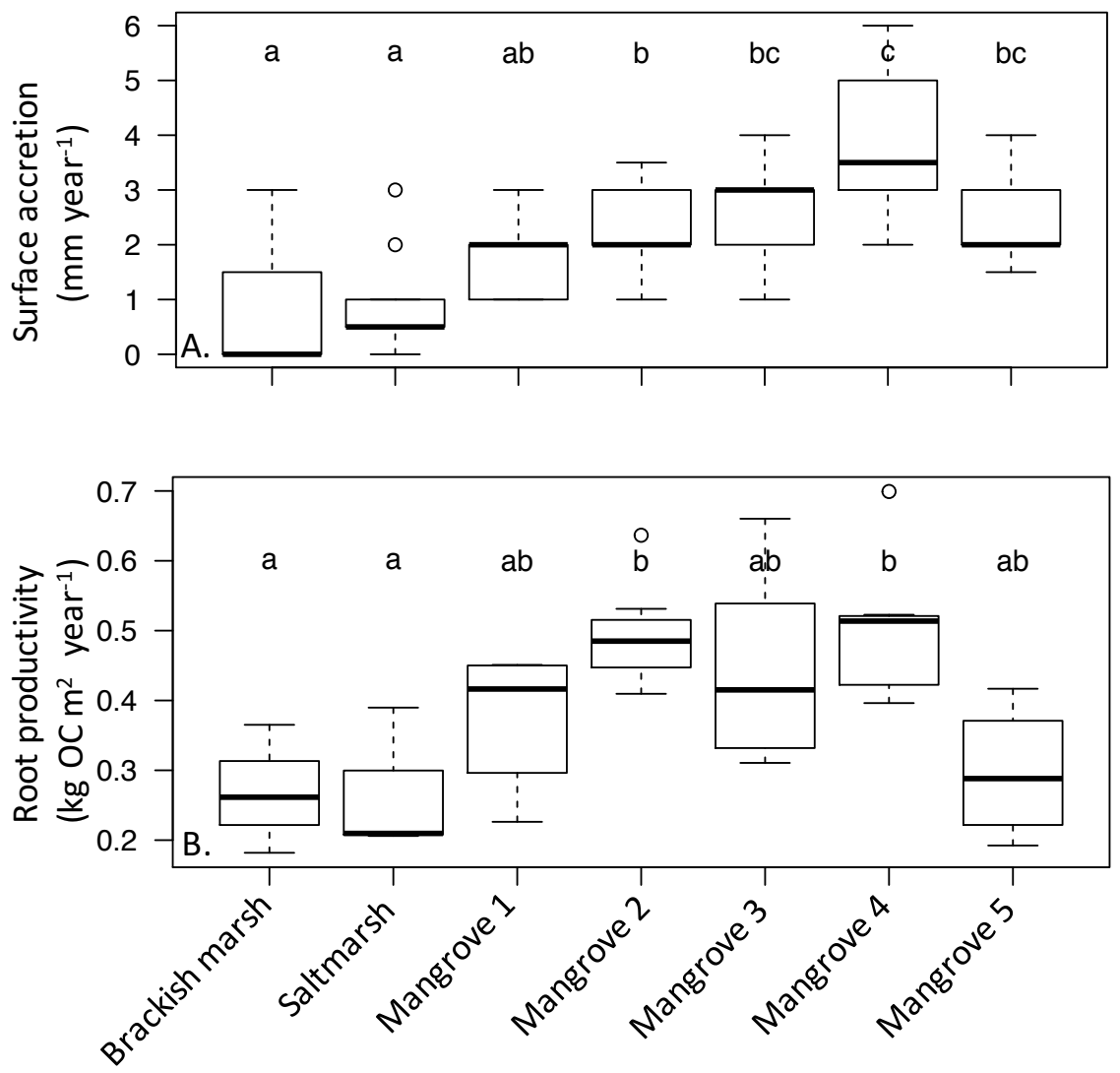


\section{CONCLUSIONS}

Coastal wetlands provide critical habitat, filter water, protect coastlines and store organic carbon (OC) more efficiently than other ecosystems and are therefore among the most valuable global ecosystem types (Costanza et al. 2014; Barbieri et al. 2011; Mcleod et al. 2011). The accumulation of OC in coastal wetland soil provides substrate to increase soil elevation (Woodroffe et al. 1990; McKee et al. 2007), but losses of belowground biomass or soil OC can also reduce elevation (Delaune et al. 1994; Deegan et al. 2012), thus wetland vulnerability to sea level rise (SLR) is strongly influenced by OC storage.

Accelerated SLR, increasing temperatures and water management is driving saltwater intrusion, altering biogeochemical conditions and the structure and function of vegetation communities (Herbert et al. 2015; Saintillan et al. 2014; Kelleway et al. 2017). Here we quantified changes in OC stocks and fluxes associated with saltwater intrusion, vegetation change (particularly mangrove encroachment) and their interaction across the landscape through space and time. To holistically address the implications of saltwater intrusion and vegetation change, we quantified changes in OC stocks and fluxes driven by 1) saltwater intrusion (salinity, phosphorus (P) and inundation) on freshwater and brackish Everglades sawgrass marshes without vegetation change, 2) vegetation identity and cover along an experimental saltmarsh to mangrove gradient without saltwater intrusion, 3) saltwater intrusion and vegetation change across a low productivity marsh to mangrove ecotone and 4) vegetation change and mangrove forest development through time along a productive marsh to mangrove ecotone. 
In Chapter I, I used freshwater and brackish marsh mesocosms to evaluate the role of salinity and Phosphorous (P) in soil elevation and OC stocks. This research demonstrated that saltwater intrusion in freshwater marsh (0-9 ppt) decreased root biomass and drove a $2.5 \mathrm{~cm}$ decrease in soil elevation over 1 year. P addition increased both root productivity and breakdown rates $(k)$ of roots and leaves with no impact on overall OC stock or elevation. In brackish marsh mesocosms, increased salinity (10-20 ppt) reduced OC storage capacity by decreasing root productivity and root biomass and increasing root $k$. Although there were no differences in elevation change among salinity treatments, all brackish marsh treatments lost elevation. Results from Chapter I show that saltwater intrusion into Everglades sawgrass marshes without vegetation shifts reduces OC storage and increases wetland vulnerability to open water conversion.

In Chapter II, I used an experimental marsh-mangrove ecotone in Port Aransas, Texas to evaluate the shifts in OC storage as vegetation communities shifted from marshes to mangroves. This research showed that mangrove vegetation promoted higher OC storage by increasing above and belowground biomass, increasing OC accretion and reducing organic matter breakdown by producing recalcitrant organic matter and reducing surface soil temperature. However, mangroves also increased belowground $k$, and decreased allochthonous marine subsidies to the wetland interior, indicating the potential for OC storage trade-offs in other ecosystems.

In Ch.III, I measured OC stocks and fluxes across the landscape in the low biomass Southeast Saline Everglades and show that saltwater intrusion decreases soil OC stocks and that mangrove recruitment increases root productivity and biomass, but does not replace soil OC storage lost from saltwater intrusion. I also identified strong interior- 
coastal gradients in soil stoichiometry (greater nitrogen, carbon to nitrogen and nitrogen to phosphorus ratios in wetland interior) and mangrove cover (greater mangrove cover near the coast). Additionally, I found that interior freshwater soil conditions increased $k$, indicating that breakdown rates are greater in interior wetlands experiencing early saltwater intrusion. I also identified a trend toward lower soil OC storage close to the coast, which indicates that saltwater intrusion drives a large scale reduction in OC storage across the landscape. Overall, these results show that the loss of salt-sensitive marsh vegetation and the patchy recruitment of scrub mangroves has driven the expansion of a "white zone," with low vegetation cover and reduced OC stocks, and that while mangrove expansion increased root biomass stocks and root productivity, vegetation change did not mitigate the overall loss of OC stocks toward the coast.

In chapter IV, I compare OC stocks and fluxes along gradients from brackish to saltwater marsh vegetation and a chronosequence of mangrove establishment in Ten Thousand Islands National Wildlife Refuge (TTINWR) to evaluate the interactions among saltwater intrusion, vegetation change and development through time. This research showed that saltwater intrusion decreased soil OC stock in marshes, but mangrove encroachment drove recovery and enhanced OC stocks over time. Brackish marsh communities had four times higher soil OC than saltmarsh, indicating a loss of soil OC with saltwater intrusion. However, soil OC increased with mangrove encroachment, becoming two times higher than saltmarsh soil OC within 10 years of mangrove encroachment, becoming similar to brackish marsh in 10- 20 years and 10 times higher than in saltmarsh within 88 years. Mangroves also had two times more aboveground biomass within ten years and 30 times more within 30 years after which aboveground 
biomass stabilized. Similarly, belowground biomass doubled after 20 years of mangrove encroachment and remained similar in older mangroves. In the more productive marsh to mangrove ecotone of TTINWR, saltwater intrusion decreased marsh OC storage, but mangrove encroachment replaced soil OC within 20 years and drove strong increases in soil OC and above and belowground biomass through time.

Our research shows that 1) moderate saltwater intrusion without mangrove encroachment will lead to a loss in OC stocks and potentially wetland elevation loss and submergence, 2) in the absence of a change in saltwater intrusion, woody mangrove expansion can enhance OC storage 3) mangrove expansion can mitigate OC loss during saltwater intrusion, but whether that translates into replacement and enhancement of OC stocks depends on mangrove recruitment and ecosystem productivity.

\section{LITERATURE CITED}

Cahoon, D. R., P. Hensel, J. Rybczyk, K. L. McKee, C. E. Proffitt, and B. C. Perez. 2003. Mass tree mortality leads to mangrove peat collapse at Bay Islands, Honduras after Hurricane Mitch. Journal of Ecology 91:1093-1105.

Deegan, L. A., D. S. Johnson, R. S. Warren, B. J. Peterson, J. W. Fleeger, S. Fagherazzi, and W. M. Wollheim. 2012. Coastal eutrophication as a driver of salt marsh loss. Nature 490:388-+.

Delaune, R. D., J. A. Nyman, and W. H. Patrick. 1994. Peat collapse, ponding and wetland loss in a rapidly submerging coastal marsh. Journal of Coastal Research 10:1021-1030.

Dessu, S. B., R. M. Price, T. G. Troxler, and J. S. Kominoski. 2018. Effects of sea-level rise and freshwater management on long-term water levels and water quality in the Florida Coastal Everglades. Journal of Environmental Management 211: 164176.

Herbert, E. R., P. Boon, A. J. Burgin, S. C. Neubauer, R. B. Franklin, M. Ardon, K. N. Hopfensperger, L. P. M. Lamers, and P. Gell. 2015. A global perspective on 
wetland salinization: ecological consequences of a growing threat to freshwater wetlands. Ecosphere 6.

Koch, M. S., C. Coronado, M. W. Miller, D. T. Rudnick, E. Stabenau, R. B. Halley, and F. H. Sklar. 2015. Climate Change Projected Effects on Coastal Foundation Communities of the Greater Everglades Using a 2060 Scenario: Need for a New Management Paradigm. Environmental Management 55:857-875.

Sklar, F. H., M. J. Chimney, S. Newman, P. McCormick, D. Gawlik, S. L. Miao, C. McVoy, W. Said, J. Newman, C. Coronado, G. Crozier, M. Korvela, and K. Rutchey. 2005. The ecological-societal underpinnings of Everglades restoration. Frontiers in Ecology and the Environment 3:161-169. 
VITA

SEAN P. CHARLES

Born, Williamsburg, Virginia

2007

B.A., Double major Environmental Science and English College of William and Mary

Williamsburg, Virginia

2013

M.S., Marine Biology

College of William and Mary

Virginia Institute of Marine Science

Gloucester Point, Virginia

2013- 2018

Doctoral Candidate

Florida International University

Miami, Florida

2011- 2012

GK-12 Teaching Fellow

National Science Foundation, \$46,000

2011-2012

Antarctic Fellow

Processes Regulating Iron Supply at the Mesoscale

Ross Sea, Antarctica

2015- 2016

FIU for Everglades Fellow

The Everglades Foundation, \$20,000

2016-2017

Doctoral Dissertation Improvement Grant National Science Foundation. DISSERTATION RESEARCH, \$19,045

$2017-2018$

Florida International University Dissertation Year Fellowship, $\$ 16,600$

2017

Puerto Rico mangrove supplement grantee

Center for Research Excellence in Science and technology, $\$ 5,000$

2012- present

Student representative, Education and Outreach Committee Society of Wetland Scientists

2014-2016

Vice President, Florida Coastal Everglades Long Term Ecological Research Program Student Group 
$1^{\text {st }}$ place student oral presentation FIU Biology Department symposium

\section{SELECTED PUBLICATIONS AND PRESENTATIONS}

Charles, S. P., J. S. Kominoski, A. R. Armitage, C. Weaver, H. Guo, S. C. Pennings. In Review. Mangroves increase organic carbon storage in an experimental marsh-mangrove gradient despite reduced marine subsidies. Ecology.

Servais, S., J. S. Kominoski, S. P. Charles, E. E. Gaiser, V. Mazzei, T. G. Troxler, B. J. Wilson. In Review. Quantifying microbial-mediated soil carbon loss with saltwater intrusion in freshwater wetlands: experimental tests of elevated salinity and phosphorus. Geoderma.

Wilson, B. J., S. Servais, S. P. Charles, V. Mazzei, E. E. Gaiser, J. S. Kominoski, J. H. Richards, T. G. Troxler. In Review. Balancing nutrient subsidy and salinity stress: shortand long-term effects of saltwater intrusion on freshwater wetland ecosystem functions. Ecology.

Wilson, B. J, S. Servais, S. P. Charles, S. E. Davis, E. E. Gaiser, J. S. Kominoski, J. H. Richards, and T. G. Troxler. In Revision. Declines in plant productivity drive carbon loss from brackish coastal wetland mesocosms exposed to saltwater intrusion. Estuaries and Coasts.

Djukic, I. S. Kepfer-Rojas, I. K. Schmidt, K. S. Larsen, C. Beier, B. Berg, Kris Verheyen [et al., including Charles, S.P.]. 2018. Early stage litter decomposition across biomes. Science of the total environment. 628-629: 1369-1394.

Guo, H. Weaver, C. Charles, S. P., Pennings, S.C., Dastidar, S. D'Odorico, P. Fuentes, J. D. Hughes, Z., Armitage, A.R. C. Weaver, A. Whitt, J. S. Komioski, Pennings, S. C. Coastal Regime Shifts: Rapid response of coastal wetlands to changes in mangrove cover. 2017. Ecology. 98: 762-772.

Troxler, T. G., G. Starr, J. N. Boyer, J. D. Fuentes, R. Jaffe [et al., including Charles, S.P.]. In Revision. Carbon cycles in the Florida Coastal Everglades socio-ecological system across scales. Pages 124- 152. In D.L. Childers, E. Gaiser, L. Ogden, editors. The Coastal Everglades: The Dynamics of Social-ecological Transformation in the South Florida Landscape. Oxford University Press.

Charles, S.P., J. S. Kominoski, S. Davis, E. E. Gaiser, S. Kelly, V. Mazzei, M. S. Ross, S. M. Servais, F. H. Sklar, T. G. Troxler, B. J. Wilson. Sea Level Rise and abiotic and biotic drivers of changes in soil organic carbon in coastal ecosystems: examples from field and manipulative studies in the Florida Everglades. Society of Wetland Scientists Meeting. 6/6/2017. San Juan, Puerto Rico. 